\title{
CRESCIMENTO DO CAPIM-TIFTON 85 SUBMETIDO A DOSES E ÉPOCAS DE APLICAÇÃO DE NITROGÊNIO APÓS O CORTE
}

\author{
LINDA MONICA PREMAZZI \\ Engenheira Agrônoma
}

Orientador: Prof. Dr. FRANCISCO ANTONIO MONTEIRO

Tese apresentada à Escola Superior de Agricultura "Luiz de Queiroz", Universidade de São Paulo, para obtenção do título de Doutor em Agronomia, Área de concentração: Solos e Nutrição de Plantas.

PIRACICABA

Estado de São Paulo - Brasil

Maio - 2001 


\title{
Dados Internacionais de Catalogação na Publicação (CIP) DIVISĀO DE BIBLIOTECA E DOCUMENTAÇĀO - Campus "Luiz de Queiroz"/USP
}

\author{
Premazzi, Linda Monica \\ Crescimento do capim-Tifton 85 submetido a doses e épocas de aplicação de nitrogênio \\ após o corte / Linda Monica Premazzi. - - Piracicaba, 2001. \\ $93 p$. \\ Tese (doutorado) - Escola Superior de Agricultura Luiz de Queiroz, 2001. \\ Bibliografia. \\ 1. Adubação nitrogenada 2. Área foliar 3. Clorofila 4. Graminea forrageira 5. Perfilho \\ I. Titulo
}

CDD 633.26

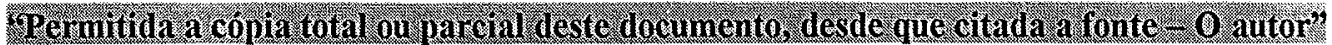




\section{AGRADECIMENTOS}

Em especial ao Prof. Dr. Francisco Antonio Monteiro pela orientação e à CAPES pela concessão da bolsa de doutorado no país e participação no Programa de Doutorado no País com Estágio no Exterior (PDEE).

Aos engenheiros agrônomos Israel Benetti e Pelerson F. Schiavuzzo pela valiosa colaboração na condução do experimento.

Ao Prof. Dr. Ricardo Ferraz de Oliveira pela orientação no experimento de determinação do fator de correção de área foliar e permissão para utilização do medidor portátil de área foliar.

Ao Prof. Dr. José Eduardo Corrente pelo auxílio nas análises estatísticas.

Ao Prof. Dr. Sila Carneiro da Silva pela amizade e discussões de temas relativos ao experimento.

Aos funcionários do Laboratório de Nutrição Mineral de Plantas da ESALQ-USP pelo auxilio no processamento e análises de material vegetal. 


\section{SUMÁRIO}

Página

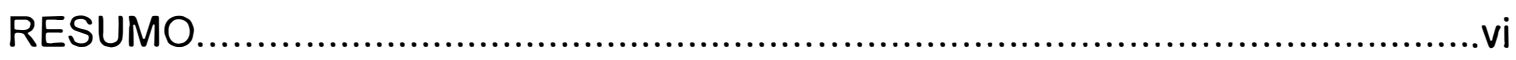

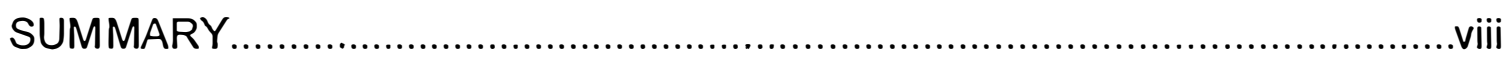

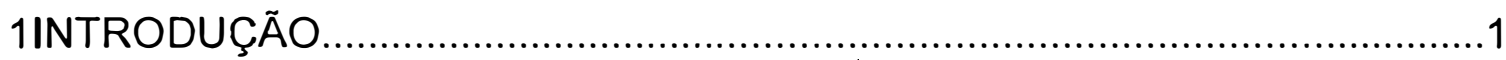

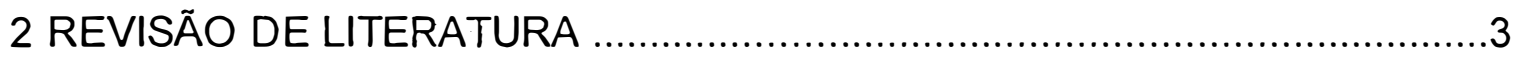

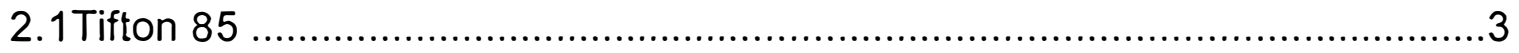

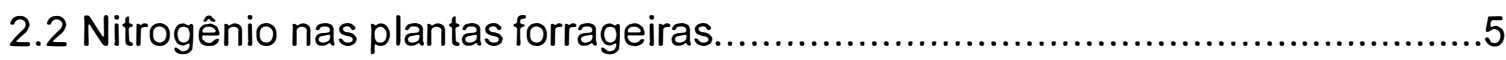

2.3 Adubação nitrogenada no capim Tifton 85............................................10

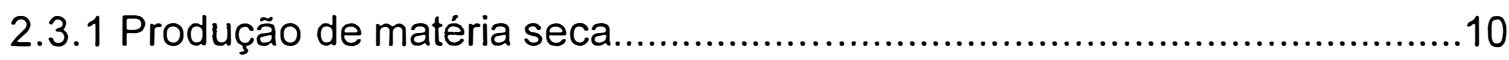

2.3.2 Relação colmo+bainha/lâmina foliar....................................................14

2.3.3 Concentração de nitrogênio no tecido vegetal.......................................15

2.4 Nitrogênio e perfilhamento de gramíneas...............................................16

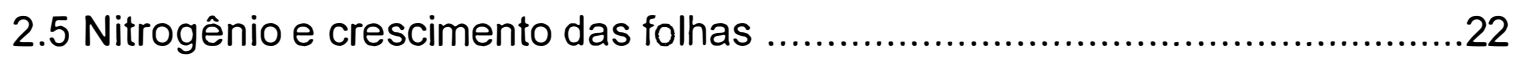

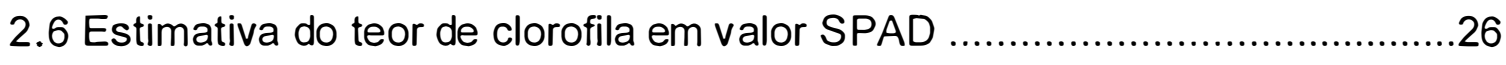

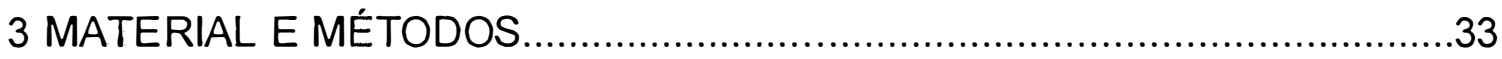

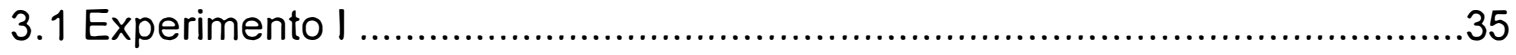

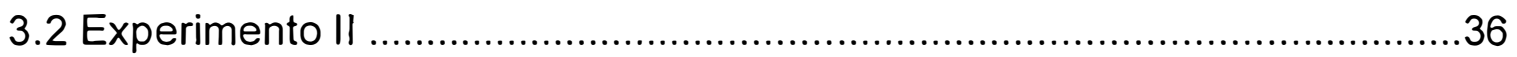

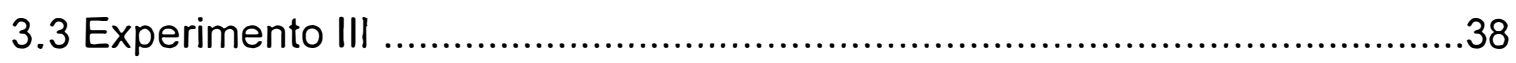

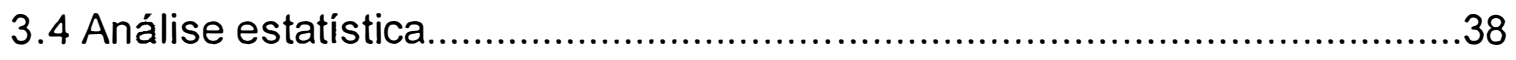

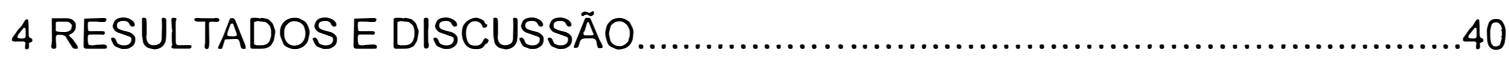

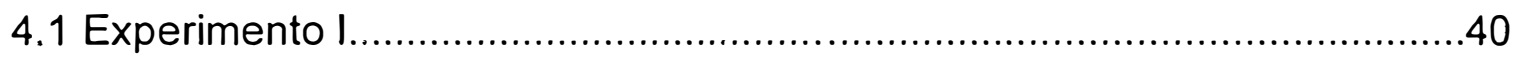

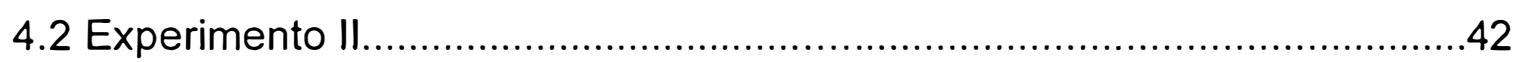

4.2.1 Produção de matéria seca da parte aérea e raizes...................................42

4.2.2 Relação colmo+bainha / lâmina foliar .......................................................46 
4.2.3 Concentração de nitrogênio no tecido vegetal.....................................48

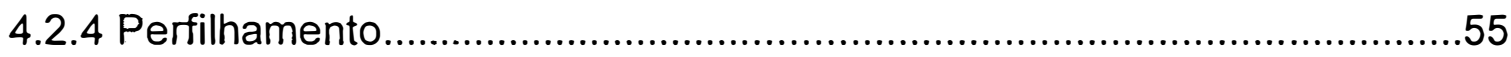

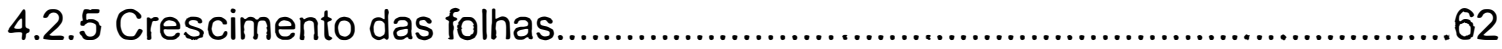

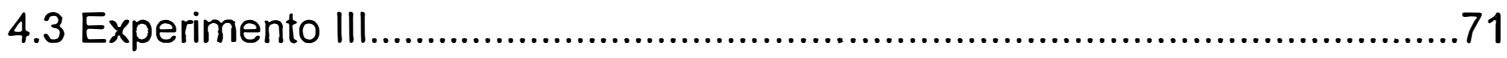

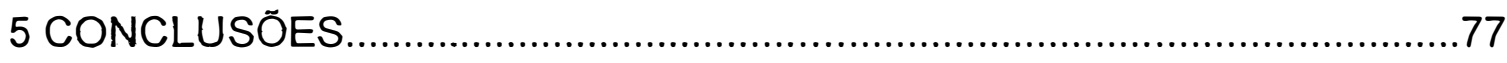

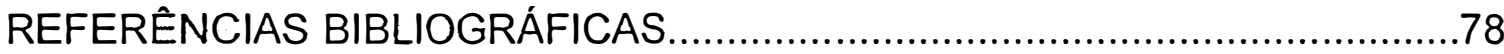




\title{
CRESCIMENTO DO CAPIM-TIFTON 85 SUBMETIDO A DOSES E ÉPOCAS DE APLICAÇÃO DE NITROGÊNIO APÓS O CORTE
}

\author{
Autor: LINDA MONICA PREMAZZI
}

Orientador: Prof. Dr. FRANCISCO ANTONIO MONTEIRO

\section{RESUMO}

Um grupo de experimentos foi conduzido com a gramínea Tifton 85 (Cynodon spp), em casa-de-vegetação, com o objetivo de avaliar a influência de doses e épocas de aplicação de nitrogênio após o corte no fator de correção de área foliar e também no crescimento das plantas, através dos parâmetros produção de matéria seca, perfilhamento, crescimento de folhas e concentração de nitrogênio no tecido. O efeito das doses de nitrogênio foi avaliado no teor de clorofila da lâmina foliar, através da leitura do valor SPAD. O estudo foi desenvolvido na forma de três experimentos, estabelecidos em vasos com capacidade para sete quilogramas de solo classificado como NEOSSOlo QUARTZARÉNICO Órtico típico, com horizonte A moderado álico fase cerrado e relevo plano. Os experimentos I e II foram estabelecidos em esquema fatorial $4 \times 2$, sendo avaliadas quatro doses e duas épocas de aplicação de nitrogênio após o corte, com quatro repetições e no experimento III foram estudadas quatro doses de nitrogênio com seis repetições. O 
delineamento experimental foi o de blocos completos ao acaso. As doses de nitrogênio estudadas nos três experimentos foram $0,80,160$ e $240 \mathrm{mg} \mathrm{kg}^{-1}$ de solo e as duas épocas de aplicação de nitrogênio foram imediatamente após o corte das plantas e após sete dias. Observou-se que as doses de nitrogênio resultaram em variação no valor do fator de correção de área foliar e aumentaram a produção de matéria seca da parte aérea até doses de 217 e $205 \mathrm{mg} \mathrm{kg}{ }^{-1}$ de solo, no primeiro e segundo cortes, respectivamente. A produção de matéria seca de raízes foi afetada pelas doses e épocas de aplicação do nitrogênio após o corte. A concentração de nitrogênio na parte aérea e nas raizes aumentou dentro das doses de nitrogênio estudadas, observando-se mais altos valores na parte aérea quando o nitrogênio foi aplicado sete dias após o corte. Houve efeito das doses de nitrogênio no número total de perfilhos e no peso de perfilhos individuais. Foram obtidos os coeficientes de correlação de 0,92 e 0,94 entre o número total de perfilhos e produção de matéria seca da parte aérea, para o primeiro e segundo crescimentos, respectivamente. $O$ nitrogênio influenciou $O$ comprimento e a área da lâmina foliar do capim, os quais estiveram associados à época de aplicação do nitrogênio e à data de avaliação dentro do período de crescimento. Observou-se variação na leitura do valor SPAD com as doses de nitrogênio e alta correlação desse valor com a concentração de nitrogênio na lâmina foliar. 


\title{
NITROGEN RATES AND TIME OF APPLICATION FOR TIFTON 85 BERMUDAGRASS GROWTH
}

\author{
Author: LINDA MONICA PREMAZZI \\ Adviser: Prof. Dr. FRANCISCO ANTONIO MONTEIRO
}

\section{SUMMARY}

Two experiments were carried out in a greenhouse to evaluate the effects of nitrogen rates and time of application after cutting in the growth of Tifton 85 (Cynodon spp). Plants were grown in an Entisol and the rates of nitrogen were $0,80,160$ and $240 \mathrm{mg} \mathrm{kg}^{-1}$ of soil and the time of application were immediatly after cutting and seven days after. These experiments were set in factorial design and they used a complete randomized block design, with four replications. In a third experiment the concentration of chlorophyll in the leaves was evaluated under the same rates of nitrogen throught SPAD readings, with six replications and same experimental design. There was an effect of nitrogen in increasing dry matter yield of plant tops. Maximum dry matter yield was estimated at nitrogen rates of 217 and $205 \mathrm{mg} \mathrm{kg}^{-1}$ of soil, for the first and second growth periods. Dry matter of roots was influenced by nitrogen and the lowest production was observed when the application of nitrogen was just after cutting. The concentration of nitrogen in plant tops and roots increased with 
nitrogen application and higher nitrogen concentration was found with nitrogen supply seven days after cutting than with the application just after cutting. The total number of tillers and the weight per tiller were affected by increasing nitrogen rates and the correlation coefficient between total number of tiller and dry matter yield of plant tops were 0.92 and 0.94 for the first and second grass growth period. Nitrogen influenced the leaf lenght and the leaf area and these effects were associated to time of nitrogen application and to date of evaluation in each growing period. The value of the index of correction (between estimated and measured values) for leaf area was changed by nitrogen rates. There was an effect of nitrogen rates in the SPAD values and high coefficient of correlation between SPAD values and concentration in the leaf laminae was observed. 


\section{INTRODUÇÃO}

A pecuária brasileira tem se fundamentado na produção de bovinos a pasto, com incentivos à utilização de recursos que venham a melhorar a produtividade das pastagens naturais e implantadas. Neste contexto estão incluídas a escolha racional de espécies e cultivares, a utilização adequada de calagem e adubação e um manejo que permita maiores retornos em termos de produtividade da forragem e do animal.

Paralelamente aos recursos forrageiros existentes, a pesquisa com plantas forrageiras tem lançado no mercado nacional novos cultivares que apresentam produtividade e qualidade diferenciadas em relação aos materiais genéticos já em uso, e que devem ser avaliadas sob determinadas condiçōes de ambiente. Neste sentido situa-se a gramínea forrageira Tifton 85 , que foi lançada nos Estados Unidos da América em 1992 e atualmente encontra-se disseminada em várias regiões do Brasil. Para que sejam obtidos bons índices de produção e qualidade é preciso conhecer o manejo adequado da forrageira em termos de adubação, momento de corte e processamento dessa planta. Assim é necessário que se conduzam no Brasil experimentos relativos à nutrição, fisiologia de crescimento e valor nutritivo e alimentar com o capimTifton 85.

A resposta ao fornecimento de nutrientes tem sido primeiramente avaliada pela produção de matéria seca da parte aérea. Contudo, estudos mais detalhados, tem incluído avaliação das características morfogênicas das forrageiras e estruturais da pastagem, como taxa de aparecimento e 
alongamento das folhas, perfilhamento e outros que são determinantes da produção de biomassa vegetal. A adubação nitrogenada é determinante para a produtividade de forrageiras, atuando nessas características e aumentando quantitativamente a produção de massa. O nitrogênio melhora ainda o valor nutritivo das forragens, promovendo mais elevados ganhos em produtividade nos animais que as utilizam. É importante também considerar a época de aplicação de nitrogênio após o corte ou pastejo, a qual pode refletir na eficiência do aproveitamento do nutriente pela planta.

A grama-bermuda Tifton 85 apresenta um grande potencial como forragem para pastagem, tanto para uso na bovinocultura de corte como de leite, devendo então ser inserida em programas de avaliação agronômica no Brasil, com um dos principais enfoques sendo a sua resposta à adubação.

Este trabalho teve como objetivo avaliar a influência de doses e épocas de aplicação de nitrogênio após o corte na determinação do fator de correção de área foliar e no crescimento do capim-Tifton 85 através dos parâmetros produção de matéria seca, perfilhamento, crescimento de folhas e concentração de nitrogênio na planta. Foi avaliado também o efeito de doses de nitrogênio na estimativa do teor de clorofila através do valor SPAD. 


\section{REVISÃO DE LITERATURA}

\subsection{Tifton 85}

O capim-bermuda "Tifton 85" (Cynodon spp.) foi desenvolvido pelo Departamento de Estado da Agricultura e pela Universidade da Geórgia, em Tifton, Estado da Geórgia, nos Estados Unidos da América, tendo sido liberado em abril de 1992. O cultivar Tifton 85 foi considerado o melhor entre muitos híbridos da geração F1 resultante do cruzamento entre Cynodon dactylon [L.] Pers. procedente da África do Sul (PI 290884) e Tifton 68 (Cynodon nlemfuensis Vanderyst). Essa forrageira apresenta porte mais alto, possui caules mais longos, folhas mais largas, com cor verde mais escura do que outros híbridos do capim-bermuda, além rizomas longos e estolões de rápida expansão (Burton et al., 1993).

Nos Estados Unidos da América as gramíneas do gênero Cynodon estão presentes nas regiões quentes que correspondem a latitudes menores que $30^{\circ} \mathrm{N}$. Em latitudes até aproximadamente $32^{\circ} \mathrm{N}$ as gramas bermuda (Cynodon dactylon) são melhor adaptadas e sobrevivem bem aos invernos moderadamente frios, em relação às gramas estrela (Cynodon nlemfuensis var. nlemfuensis e Cynodon aethiopicus), que estão presentes mais em direção ao sul da Flórida (Pedreira et al., 1998 ).

Mislevy \& Pate (1996) apresentaram como vantagens do Tifton 85 um rápido estabelecimento e bom desenvolvimento em condições de clima frio, com temperaturas de 16 a $27^{\circ} \mathrm{C}$ e dias curtos, desde que adequadas condições 
de umidade e fertilidade do solo estejam presentes. O Tifton 85 e a grama estrela Florico são consideradas os dois cultivares com mais alta digestibilidade para o gênero Cynodon.

Em experimentos conduzidos por Hill et al. (1993), o Tifton 85 apresentou produção de matéria seca de $18,6 \mathrm{Mg} \mathrm{ha}^{-1}$ ano-1 $^{-1}$ no periodo de 1985 a 1987 e de $14,7 \mathrm{Mg} \mathrm{ha}^{-1} \mathrm{ano}^{-1}$ no periodo de 1989 a 1991, com valores de digestibilidade "in vitro" da matéria seca de 60,3 e 57,3\%, respectivamente. Essa produção foi, em média, $26 \%$ mais elevada e com valores de digestibilidade "in vitro" da matéria seca $11 \%$ superior ao Coastal bermuda. Em experimento de pastejo, o Tifton 85 proporcionou um ganho de peso diário por animal similar ao Tifton $78(0,65 \times 0,67 \mathrm{~kg} / \mathrm{dia})$, tendo sido observados valores também similares quanto à qualidade da forragem. Contudo, o número de animais em dias de pastejo promovido pelo Tifton 85 foi $38 \%$ superior em relação ao Tifton 78, proporcionando um ganho de peso animal por área $46 \%$ superior (1156 kg ha-1 $\times 789 \mathrm{~kg} \mathrm{ha}^{-1}$ ), caracterizando uma maior produção de forragem pelo Tifton 85 . Nesse experimento os valores de proteina bruta do Tifton 85 variaram de 114 a $156 \mathrm{~g} \mathrm{~kg}^{-1}$.

A linha de pesquisa norte-americana envolvendo esta forrageira tem enfocado aspectos de produção de matéria seca, valores nutritivo e alimentar da forragem, capacidade de suporte da pastagem e desempenho animal (Hill et al., 1993; Pedreira, 1995; West et al., 1997; West et al., 1998; Mandebvu et al., 1998a; Mandebvu et al., 1998b; Mandebvu et al., 1999).

No Brasil, experimentos com enfoque na produção de matéria seca e no valor nutritivo do Tifton 85 também tem sido realizados principalmente na região sudeste do país, incluindo-se estudos nas áreas de adubação e fisiologia de crescimento da forrageira.

Gomide (1996) avaliou o crescimento de cinco cultivares de Cynodon no Estado de São Paulo, em 11 idades de crescimento, com o fornecimento de nitrogênio de $100 \mathrm{~kg} \mathrm{ha}^{-1}$, no início do periodo experimental. Para o Tifton 85 
foram obtidas as produções de matéria seca de 4970, 5168 e $9897 \mathrm{~kg} \mathrm{ha}^{-1}$ para cortes realizados aos 28,42 e 56 dias de crescimento, respectivamente. Os teores de proteina bruta para esses periodos foram de 142, $103{\mathrm{e} 86 \mathrm{~g} \mathrm{~kg}^{-1}}^{-1}$ respectivamente.

Carnevalli et al. (1999) estudaram a resposta do Tifton 85 submetido a alturas em pastejo contínuo. Observaram, para o periodo de verão, uma diminuição na concentração de proteina bruta de 213 para 180 e para $159 \mathrm{~g} \mathrm{~kg}^{-1}$ e de digestibilidade "in vitro" da matéria seca de 85,2 para 80,7 e para $76,2 \%$ quando comparam as alturas de 5,10 e $15 \mathrm{~cm}$, respectivamente. $O$ acúmulo de matéria seca da parte aérea variou de 90 a $113 \mathrm{~kg} \mathrm{ha}^{-1} \mathrm{dia}^{-1}$ entre essas alturas. A capacidade de suporte, medida em peso vivo animal, diminuiu de 2520 para $1790 \mathrm{~kg} \mathrm{ha}^{-1} \mathrm{dia}^{-1} \mathrm{com}$ as alturas de 5 e $10 \mathrm{~cm}$ e a partir daí foram semelhantes.

\subsection{Nitrogênio nas plantas forrageiras}

A matéria seca das plantas contém entre 2 e $4 \%$ de nitrogênio, sendo este um constituinte indispensável de compostos orgânicos importantes no metabolismo vegetal, tais como aminoácidos, proteinas e ácidos nucleicos. A fração protéica do nitrogênio constitui ao redor de $80-85 \%$ do total de nitrogênio nas plantas verdes (Mengel \& Kirkby, 1987), e nesta, estão presentes as enzimas responsáveis pela fixação do carbono na fotossintese.

É conhecida a importância da adubação nitrogenada na produção de pastagens. A disponibilidade de nitrogênio é o fator dominante que controla os processos de crescimento e desenvolvimento da planta e provavelmente 0 mais importante a limitar a produção da biomassa permitida pelas condições climáticas em ecossistemas naturais (Nabinger, 1996). Whitehead (1995) apontou, em relação às gramineas, que a influência do suprimento de nitrogênio no crescimento está presente em muitos aspectos de sua morfologia 
e fisiologia. A deficiência de nitrogênio restringe o número de perfilhos que se desenvolvem e também o crescimento e eficiência fotossintética das folhas. $O$ crescimento da parte aérea é também mais afetado que o crescimento das raízes.

O acúmulo de carbono em material vegetal, que determina a produção primária de uma pastagem é resultante de processos fisiológicos influenciados pelo estado nutricional de nitrogênio das plantas (Lemaire, 1997). Desde que a aquisição de nitrogênio no solo também está dependente da obtenção de carbono pelas plantas, a dinâmica dos fluxos de carbono e de nitrogênio, segundo esse autor, deve ser estudada conjuntamente.

De acordo com Nabinger (1996) a limitação dos fatores do meio, como temperatura, nutrição mineral e água, pode neste sentido, agir tanto na demanda em carbono (morfogênese da parte aérea) como na oferta (fotossintese).

Nabinger (1997) apresentou um modelo de acúmulo de biomassa vegetal baseado em Gosse et al. ${ }^{1}$ Nesse modelo a produção de matéria seca é uma função da radiação fotossinteticamente ativa (PAR) absorvida e da eficiência da utilização da radiação (EUR). A relação entre essas variáveis, determinando a produção de forragem, tem sido estudada em relação ao nitrogênio.

Robson \& Parsons (1978) observaram que a taxa de eficiência fotossintética líquida, medida em folhas individuais de azevém (Lolium perenne), foi maior nas plantas que cresceram em solução nutritiva contendo nitrogênio em $300 \mathrm{mg} \mathrm{L}^{-1}$ em relação àquelas que cresceram em solução com nitrogênio de $3 \mathrm{mg} \mathrm{L}^{-1}$, que chegaram a fixar $30 \%$ a menos de carbono.

\footnotetext{
${ }^{1}$ Gosse, G.; Varlet-Grancher, C.; Bonhomme,R.; Chartier, M.; Allirand, J; Lemaire. Agronomie, v.6, n.1, p.47-56, 1986.
} 
Woledge \& Pearse (1985) observaram um aumento de $50 \%$ na taxa de fotossintese líquida por unidade de área foliar em azevém suprido com nitrogênio de $132 \mathrm{~kg} \mathrm{ha}^{-1}$ em relação às plantas que não receberam nitrogênio.

O conteúdo de nitrogênio na folha pode refletir o potencial de assimilação de $\mathrm{CO}_{2}$, pela planta, conforme foi demonstrado por Sinclair \& Horie (1989). Os autores observaram uma alta correlação entre a taxa de assimilação de $\mathrm{CO}_{2}$ pela folha por unidade de área e o conteúdo de nitrogênio por unidade de área com modelos diferenciados para as culturas de milho, soja e arroz.

Bélanger et al. (1992a) estudaram o crescimento de festuca (Festuca arundinaceae) fertilizada com doses de nitrogênio. Observou-se que a eficiência no uso da radiação aumentou de 0,67 para 1,68 $\mathrm{g} \mathrm{DM} \mathrm{MJ}^{-1} \mathrm{com}$ as doses de nitrogênio de 0 a $160 \mathrm{~kg} \mathrm{ha}^{-1}$, um aumento atribuído pelos autores à melhoria na eficiência fotossintética e/ou ao aumento na partição de carbono para a parte aérea. Verificaram também aumento na radiação fotossinteticamente ativa (PAR) acumulada, que variou de 222 a $330 \mathrm{MJ} \mathrm{m}^{-2}$, provavelmente devido ao desenvolvimento da área foliar. A produção de matéria seca da parte aérea aumentou de 157 para $544 \mathrm{~g} \mathrm{~m}^{-2}$ com o aumento da dose de nitrogênio.

Lawlor (1995), apresentou resultados da cultura de trigo (Triticum aestivum cv. Avalon) submetida a doses de nitrogênio de 0, 40,75 e $300 \mathrm{~kg} \mathrm{ha}^{-1}$. Observou com a diminuição das doses de nitrogênio de 300 para $0 \mathrm{~kg} \mathrm{ha}^{-1}$ que houve diminuição na produção de matéria seca de 2240 para $690 \mathrm{~g} \mathrm{~m}^{-2}$, no índice de área foliar máximo de 5,5 para 1,2, na PAR absorvida de 642 para $298 \mathrm{MJ} \mathrm{m}^{-2}$ estação-1 e na eficiência de conversão de energia de 3,49 para $2,31 \mathrm{~g} \mathrm{MJ}^{-1}$ em plantas irrigadas. A diminuição na produção de matéria seca estaria mais associada a um menor desenvolvimento da área foliar e a uma diminuição na interceptação de luz que à redução na fotossíntese 
e na eficiência na conversão da energia, responsáveis por efeitos em menor magnitude na produção de matéria seca.

O nitrogênio atua no sentido de promover a repartição prioritária do carbono para a parte aérea. Em uma situação de recursos escassos ocorre uma limitação do crescimento aéreo, constituindo-se uma "economia" que, traduzindo-se por maior utilização do carbono no crescimento radicular, permite à população vegetal realizar uma melhor exploração dos recursos mais limitantes do meio (Nabinger, 1997).

Robson \& Parsons (1978) observaram os efeitos do nitrogênio no crescimento de azevém em solução nutritiva contendo nitrogênio de 3 e 300 $\mathrm{mg} \mathrm{L}^{-1}$. Constataram ao final do periodo experimental, que o peso do material seco da parte aérea (descontando-se a fração folhas mortas) na dose de nitrogênio de $3 \mathrm{mg} \mathrm{L}^{-1}$ foi $30 \%$ menor em relação à dose mais alta, porque as plantas deficientes em nitrogênio colocaram quase duas vezes mais matéria seca nas raizes como seu compartimento de reserva. Os pesos para as frações folha morta e bainha estiveram iguais, mas o peso da lâmina foliar viva foi cerca de $45 \%$ menor na mais baixa dose de nitrogênio. O efeito da deficiência de nitrogênio na partição de matéria seca das plantas foi observado através da diminuição no coeficiente entre peso seco da raiz em relação ao peso total da planta, que diminuiu de 23 para $9 \%$ na dose de nitrogênio de $300 \mathrm{mg} \mathrm{L}^{-1}$ para próximo de $20 \%$ na dose $3 \mathrm{mg} \mathrm{L}^{-1}$.

Boot \& Mensink (1990) estudaram as respostas ao suprimento de nitrogênio de cinco gramíneas submetidas à doses de 1,0 e 0,05 $\mathrm{mM} \mathrm{NH}_{4} \mathrm{NO}_{3}$. Verificaram que a fração biomassa da raiz / parte aérea foi maior na dose mais baixa de nitrogênio na solução, tendo sido observados os valores de 0,51 e 0,46 para a espécie procedente do solo de alta fertilidade e 0,35 e 0,28 para plantas procedentes de solo de baixa fertilidade, para as condições de baixa e alta dose de nitrogênio, respectivamente. 
Bélanger et al. (1992b) testaram o efeito da fertilização com nitrogênio na partição do carbono em festuca através da técnica de $C^{14}$, determinando o coeficiente de partição de carbono para as raízes. As doses de nitrogênio utilizadas foram 0,80 e $240 \mathrm{~kg} \mathrm{ha}^{-1}$ no verão, 0,40 e $160 \mathrm{~kg} \mathrm{ha}^{-1}$ no outono e 0 , 60,120 e $180 \mathrm{~kg} \mathrm{ha}^{-1}$ na primavera, sempre aplicados após a desfolha. $\mathrm{Na}$ ausência de adubação nitrogenada houve uma maior partição do carbono em direção às raízes, tendo sido observados os valores de coeficientes de partição de carbono para as raízes de 17,0; 15,8 e 11,0\% em condição não limitante de nitrogênio e 31,3; 26,5 e 26,7\% em condições limitantes nas estações de verão, outono e primavera, respectivamente. Esses resultados foram interpretados em termos de um equilíbrio funcional entre parte aérea e raízes, sendo que uma mais alta prioridade é dada para as raízes, quando a absorção é reduzida em condições de crescimento deficiente em nitrogênio.

Andrews et al. (1992), estudando o crescimento de cereais submetidos a doses de nitrato em solução nutritiva, constataram um aumento de produção de matéria seca com o suprimento de nitrato de 0,1 a $5,0 \mathrm{~mol} \mathrm{~m}^{-3}$ de nitrato, sendo o efeito em produção maior nas frações colmo+bainha e lamina foliar em relação às raízes. Por consequência a proporção de matéria seca parte aérea/raízes na planta aumentou com acréscimo de nitrato até a dose de $\quad 5,0 \mathrm{~mol} \mathrm{~m}^{-3}$. Em relação às gramíneas forrageiras observaram que a proporção da matéria seca da raiz em relação ao peso total da planta variou de 43 e $30 \%$, 45 e $37 \%$, e 50 e $36 \%$ considerando as doses de nitrato de 0,5 e $5,0 \mathrm{~mol} \mathrm{~m}^{-3}$ e as forrageiras Lolium multiflorum, Lolium perenne e Dactylis glomerata, respectivamente.

Segundo Schenk et al. (1996) a partição da biomassa entre parte aérea e raízes é controlada pela concentração de nitrogênio na planta. Os autores observaram para azevém uma diminuição na proporção de matéria seca da raiz de 54,1 para $26,8 \%$ em relação ao total de biomassa da planta quando as doses de nitrogênio variaram de 0 até $765 \mathrm{mg} / \mathrm{vaso}$. Acrescentaram 
ainda que a alocação da biomassa para a raiz esteve negativamente relacionada à concentração de nitrogênio na planta, com um $R^{2}=0,91$.

\subsection{Adubação nitrogenada no capim-Tifton 85}

\subsubsection{Produção de matéria seca}

A importância da aplicação de nitrogênio, fósforo e potássio e outros nutrientes para a produção de elevadas quantidades de forragem de Tifton 85 foi destacada por Hill et al. (1996). O nitrogênio, na ausência de outro fator limitante, é reconhecido como o nutriente de influência mais marcante na produtividade das gramineas forrageiras, sendo que para os capins do gênero Cynodon é o nutriente com maior número de trabalhos disponíveis na literatura (Monteiro, 1998).

Martim (1997), trabalhando com Latossolo Vermelho-Amarelo, estudou o comportamento dos capins bermuda Tifton 85 e Coastcross 1 submetidos a doses de nitrogênio e de potássio equivalentes a 20, 100 e 180 $\mathrm{kg} \mathrm{ha}^{-1}$ e 15, 75 e $135 \mathrm{~kg} \mathrm{ha}^{-1}$, respectivamente. Relatou que tanto o suprimento de nitrogênio como o de potássio aumentaram a produção de matéria seca da parte aérea das forrageiras. Os aumentos de produção em função das doses de nitrogênio, na dose mais alta de potássio, foram de 43 e $113 \%$, para o segundo e terceiro períodos de crescimento, respectivamente. Nesse experimento não foi observada diferença significativa entre os capins estudados, quanto a produção de matéria seca.

Gomes et al. (1997) submeteram cinco cultivares de Cynodon a duas doses de nitrogênio ( 0 e $400 \mathrm{~kg} \mathrm{ha}^{-1}$ ) e observaram efeito significativo da adubação nitrogenada na produção de matéria seca da parte aérea do Tifton 85 , com produção de matéria seca de $13783 \mathrm{~kg} \mathrm{ha}^{-1}$ no periodo chuvoso e $2375 \mathrm{~kg} \mathrm{ha}^{-1}$ nas secas na dose de nitrogênio $400 \mathrm{~kg} \mathrm{ha}^{-1}$. Esses valores foram 
50 e $24 \%$ superiores à não aplicação do nitrogênio, respectivamente. O Tifton 85 adubado apresentou maior produção de matéria seca em relação aos outros quatro cultivares estudados (estrela de Porto Rico, estrela roxa 5, Coastcross e Tifton 44) no período das águas, e produção inferior aos demais capins na época das secas. O Tifton 85 foi ainda o cultivar que apresentou mais baixa relação colmo:folha.

Paulino et al. (1997) estudaram três de doses de nitrogênio 0, 50 e $150 \mathrm{~kg} \mathrm{ha}^{-1}$ em Tifton 85 e observaram incrementos significativos na produção total de matéria seca da parte aérea e no nitrogênio acumulado. Esses efeitos foram representados por efeitos por efeitos lineares da aplicação dessas doses.

Alvim et al. (1998) constataram aumentos de produção de matéria seca da parte aérea no Tifton 85 submetido a doses de nitrogênio de 0,100 , 200, 400 e $600 \mathrm{~kg} \mathrm{ha}^{-1} \mathrm{ano}^{-1}$. A máxima produção anual de $23,1 \mathrm{Mg} \mathrm{ha}^{-1} \mathrm{ano}^{-1}$ foi obtida com a dose de nitrogênio de $600 \mathrm{~kg} \mathrm{ha}^{-1} \mathrm{ano}^{-1}$, nos regimes de cortes de seis semanas na época das chuvas e de oito na época das secas. Observaram também um aumento na concentração de proteína bruta na forragem com as doses de nitrogênio, com variação de 60 a $201 \mathrm{~g} \mathrm{~kg}^{-1}$ de proteina bruta, considerando os regimes de cortes de quatro semanas na época das águas e de seis semanas na época das secas. Os autores concluíram que aplicaçōes de nitrogênio de $400 \mathrm{~kg} \mathrm{ha}^{-1} \mathrm{e}$ intervalos entre cortes de quatro semanas na época das chuvas e de seis na época das secas constituem o manejo adequado para o Tifton 85, para a Zona da Mata de Minas Gerais.

Vieira et al. (1999) obtiveram produção média de $15,32 \mathrm{Mg} \mathrm{ha}^{-1}$ de matéria seca (média dos intervalos entre cortes de 20, 40 e 60 dias) com concentração média de proteína bruta de $145 \mathrm{~g} \mathrm{~kg}^{-1}$, quando utilizaram nitrogênio à base de $175 \mathrm{~kg} \mathrm{ha}^{-1} \mathrm{ano}^{-1}$. Esses autores não observaram diferença significativa entre a produção do Tifton 85 e da missioneira gigante (Axonopus 
jesuiticus) utilizada como referência. Para a concentração de proteina bruta o Tifton 85 foi, em números absolutos, superior à missioneira.

Alves (2000) estudou o rendimento forrageiro e o valor nutritivo do capim Tifton 85 submetido doses de nitrogênio de $0,100,200,300$ e $400 \mathrm{~kg} \mathrm{ha}^{-1} \mathrm{ano}^{-1}$, colhido ao atingir 30,40 e $50 \mathrm{~cm}$ de altura. Observou que o aumento das doses de nitrogênio possibilitou um aumento no número de cortes, dentro da altura pré-estabelecida para o corte, durante o periodo anual considerado. As plantas adubadas com nitrogênio de $100 \mathrm{~kg} \mathrm{ha}^{-1}$ permitiram a realização de três cortes ao atingirem 30 e $40 \mathrm{~cm}$, enquanto que as colhidas a $50 \mathrm{~cm}$ possibilitaram dois cortes. As parcelas adubadas com 300 e $400 \mathrm{~kg} \mathrm{ha}^{-1}$ possibilitaram a realização de quatro cortes, excetuando-se aquelas referentes a plantas colhidas ao atingirem $50 \mathrm{~cm}$ que proporcionaram apenas três cortes no segundo ano. Para o rendimento acumulado de matéria seca na parte aérea no primeiro e no segundo ano experimentais, detectou efeito linear de alturas e doses de nitrogênio. No primeiro ano foram observadas produções de 2,78 e 19,93; 3,34 e 18,96; e 5,00 e 24,22 $\mathrm{Mg} \mathrm{ha}^{-1}$, respectivamente, para as plantas recebendo nitrogênio de 0 e $400 \mathrm{~kg} \mathrm{ha}^{-1}$ e colhidas aos 30,40 e $50 \mathrm{~cm}$ de altura respectivamente. Para o segundo ano os rendimentos de matéria seca foram de 1,95 e 16,99; 3,22 e 18,47; e 3,05 e $21,17 \mathrm{Mg} \mathrm{ha}^{-1}$ para plantas recebendo 0 e $400 \mathrm{~kg} \mathrm{ha-1}$ e colhidas ao atingirem 30,40 e $50 \mathrm{~cm}$ de altura, respectivamente.

Um outro aspecto relacionado a aplicação de nitrogênio em áreas de pastagens refere-se à época de aplicação após o corte ou pastejo. Nabinger (1997) destacou a importância da imediata disponibilidade de nitrogênio já no momento do corte, quando o objetivo é maximizar a densidade dos perfilhos e atingir rapidamente $o$ indice de área foliar (IAF) ótimo. Whitehead (1995), apontou que em situações de corte ou pastejo o uso mais eficiente do fertilizante nitrogenado é encontrado quando a aplicação é feita imediatamente após o corte ou pastejo. 
Para o Tifton 85 não foram encontrados na literatura trabalhos referentes à época de aplicação de nitrogênio após o corte, tendo sido encontradas algumas informações com outras espécies. Vicente-Chandler et al. (1962) obtiveram mais elevadas produções de matéria seca da parte aérea para o capim-guiné (Panicum maximum) quando o nitrogênio foi aplicado imediatamente após o corte, em comparação com a aplicação total ou parcial em 25 dias após o corte. As proporções de recuperação de nitrogênio pelo capim-guiné foram de 46,6, 39,8 e 37,6\% para as aplicações de nitrogênio imediatamente após o corte, 25 dias após o corte e metade após o corte e 0 restante 25 dias após, respectivamente.

Cecato et al. (1994) estudaram o capim Aruana (Panicum maximum cv Aruana) em um Latossolo Vermelho-Escuro nas doses de nitrogênio de 0 , 100 e $200 \mathrm{~kg} \mathrm{ha}^{-1}$ e duas formas de aplicação, com a primeira constando de um aplicação única após o corte e a segunda com as doses de nitrogênio divididas entre o corte e 15 dias após. Não foi observado efeito das combinações entre doses e formas de aplicação de nitrogênio no vigor da rebrota, representado pela produção matéria seca da parte aérea ( $\mathrm{kg} \mathrm{MS} \mathrm{ha}^{-1} \mathrm{dia}^{-1}$ ) avaliada 21 dias após o corte.

Silva et al. (1996) recomendaram para pastagens de capim-elefante (Pennisetum purpureum) que a aplicação de nitrogênio deve ser feita nos primeiros 5 a 7 dias após o corte ou pastejo, período no qual a planta concentra seu perfilhamento e são esperadas as mais altas respostas em porcentagem de recuperação de nitrogênio. Para gramineas do gênero Cynodon, Silva (1995) indicou que as adubações de restituição devem ser realizadas após o corte. 


\subsubsection{Relação colmo+bainha/lâmina foliar}

A composição das plantas em termos da relação colmo+bainha/lâmina foliar no reflete valor nutritivo da forragem, no que diz respeito a digestibilidade e composição mineral. Gomide (1996) obteve relações folha/colmo variando entre valores de $0.89 ; 1.32 ; 0,96 ; 1,11$ e 1,04 para o Tifton 85 avaliado em idades desde os $14,21,28,35$ e 42 dias de crescimento, respectivamente.

Martim (1997) observou uma diminuição na relação colmo+bainha/lâmina foliar, em função das doses de nitrogênio (20 a $180 \mathrm{~kg} \mathrm{ha}^{-1}$ ) para o Tifton 85 e Coastcross-1 (Cynodon dactylon), revelando um crescimento proporcionalmente maior em folhas com as doses de nitrogênio. Os valores para a relação haste+bainha/lâmina estimados para o Tifton 85 na dose de nitrogênio de $20 \mathrm{~kg} \mathrm{ha}^{-1}$ foram 1,0 e 1,47. Carnevalli et al. (1999) verificaram uma proporção colmo+bainha/lâmina foliar que variou entre 2,8 e 3,3 para o Tifton 85 submetido a alturas de pastejo.

Alves (2000) pesquisou o valor nutritivo do capim-Tifton 85 e constatou interação significativa entre dose de nitrogênio aplicada e ano estudado e dose de nitrogênio aplicado e altura das plantas ao tempo do corte, com a análise de regressão mostrando resposta linear, em função do nitrogênio, para a altura ao tempo de corte. Estimaram aumentos na relação lâmina foliar/colmo de 0,0037 e 0,0016 unidades por quilograma de nitrogênio aplicado, respectivamente no primeiro e segundo anos experimentais. As médias dos valores obtidos para relação lâmina foliar/colmo, por corte, foi de 0,75 e 1,26; 0,95 e 1,23; e 0,46 e 1,01 para plantas recebendo nitrogênio de 0 e $133 \mathrm{~kg} \mathrm{ha}^{-1}$, colhidas ao atingirem 30,40 e $50 \mathrm{~cm}$ de altura, respectivamente.

Tomando-se como referência outra forrageira do gênero Cynodon Herrera et al. (1987) avaliaram o efeito de três doses de nitrogênio (0, 200 e $400 \mathrm{~kg} \mathrm{ha}^{-1} \mathrm{ano}^{-1}$ ) e 12 idades de avaliação (1 a 12 semanas) no crescimento de Coastcross. Observaram que a porcentagem de folha e colmo foram 
afetadas pela interação nitrogênio e idade da planta, obtendo-se diminuição na porcentagem de folhas com os aumentos na dose de nitrogênio e na idade da planta.

Alvim et al. (1996), trabalhando com Coastcross sob quatro doses de nitrogênio $\left(0,250,500\right.$ e $\left.750 \mathrm{~kg} \mathrm{ha}^{-1} \mathrm{ano}^{-1}\right)$ e cada dose associada a seis freqüências de corte, verificaram que no período das chuvas a relação folha/colmo foi maior do que no período da seca. Na época das chuvas essa relação variou de 0,8 a 1,7, enquanto que na época da seca a variação foi de 0,7 a 1,3. Na época das chuvas houve uma tendência de redução na relação folha/colmo com o aumento das doses de nitrogênio, sendo observado o inverso na época da seca.

\subsubsection{Concentração de nitrogênio no tecido vegetal}

A concentração de nitrogênio nos tecidos é um parâmetro de avaliação qualitativa da forragem e está diretamente ligado à adubação nitrogenada e idade da planta. Hill et al. (1993) obtiveram valores para concentração de proteina bruta que variaram entre 114 a $156 \mathrm{~g} \mathrm{~kg}^{-1}$ para 0 Tifton 85.

Martim (1997) obteve valores para a concentração de nitrogênio na matéria seca da parte aérea no Tifton 85 de 10,04 e $19,25 \mathrm{~g} \mathrm{~kg}^{-1}$ para as doses de nitrogênio de 20 e $180 \mathrm{~kg} \mathrm{ha}^{-1}$, na dose de potássio de $15 \mathrm{~kg} \mathrm{ha}^{-1}$, enquanto na dose de potássio de $135 \mathrm{~kg} \mathrm{ha}^{-1}$ os valores observados foram 9,17 e $17,01 \mathrm{~g} \mathrm{~kg}^{-1}$, respectivamente. Constatou efeito significativo das doses de nitrogênio na concentração de nitrogênio na parte aérea e esse efeito foi representado por modelo linear.

Alvim et al. (1998), verificaram aumento na concentração média anual de proteína bruta do Tifton $85 \mathrm{com}$ o incremento de nitrogênio, tendo sido 
observados valores entre 59 e $217 \mathrm{~g} \mathrm{~kg}^{-1}$, para as doses de nitrogênio de 0 e $600 \mathrm{~kg} \mathrm{ha}^{-1} \mathrm{ano}^{-1}$, respectivamente.

Alves (2000) observou para o Tifton 85 respostas lineares para a concentração de proteina bruta em função das doses de nitrogênio e alturas de corte das plantas, nas frações lâmina e colmo e na planta inteira. Os valores estimados para proteína bruta ponderada da planta inteira variaram de 74 a 181; 55 a 160 e 36 a $144 \mathrm{~g} \mathrm{~kg}^{-1}$, para plantas colhidas ao atingirem 30,40 e 50 $\mathrm{cm}$ de altura, recebendo adubação com nitrogênio de 0 e $133 \mathrm{~kg} \mathrm{ha-1}$, respectivamente. A eficiência de resposta foi estimada em de 0,98; 0,5 e $0,8 \mathrm{~g} \mathrm{~kg}^{-1}$ de proteína bruta por quilograma de nitrogênio aplicado, para lâmina, colmo e planta inteira, respectivamente. Por outro lado, descreveu decréscimos de 1,$8 ; 1,4$ e $1,9 \mathrm{~g} \mathrm{~kg}^{-1}$ na concentração de proteína bruta, para cada unidade de aumento na altura das plantas, para as frações lâmina, colmo e para a planta inteira, respectivamente.

\subsection{Nitrogênio e perfilhamento de gramíneas}

Os perfilhos tem origem nas gemas que estão presentes na axila das folhas, e possuem estrutura similar àqueles a partir do qual foram formados. As folhas dos perfilhos também possuem gemas axilares, que podem dar origem a novos perfilhos e assim sucessivamente. Os perfilhos da haste principal são denominados primários e os surgidos posteriormente, secundários, terciários, em função da hierarquia de aparecimento (Langer, 1963). A densidade de perfilhos tem sua importância associada a outras características estruturais da pastagem, como o número de folhas por perfilho e o tamanho da folha, os quais são componentes determinantes do índice de área foliar (IAF). O IAF é o principal fator influenciando a interceptação da luz e por consequência a dinâmica de rebrota da pastagem (Chapman \& Lemaire, 1993). 
O perfilhamento representa duas importantes funções na vida da planta, pois ajuda no estabelecimento de plântulas e na regeneração das plantas seguindo a remoção do meristema apical após o corte ou o pastejo (Jewis, 1972). A densidade de perfilhos está relacionada à taxa de aparecimento de folhas pelo conceito de "sítio de preenchimeto", o qual permite uma estimativa da taxa potencial de perfilhamento (Chapman \& Lemaire, 1993).

A alta disponibilidade de nitrogênio pode aumentar a proporção de perfilhos que se desenvolvem nos sítios potenciais e consequentemente a taxa de perfilhamento, sem modificação na taxa de aparecimento de folhas (Cruz \& Boval, 1999). Segundo Wilman \& Wright (1983) o nitrogênio aplicado pode ter um efeito expressivo no número e particularmente no tamanho dos perfilhos e estas características da pastagem podem ser manipuladas combinando-se 0 suprimento de nitrogênio ao manejo da desfolha da planta.

Outros fatores também afetam o perfilhamento, como a intensidade luminosa, o suprimento de água, a nutrição mineral, o florescimento, o fotoperiodo, os reguladores de crescimento e o regime de cortes (Langer, 1963). Fatores que afetam a eficiência fotossintética da planta, como o sombreamento, reduzem o perfilhamento por interferir com o nível de carboidratos através dos mecanismos mediados pela ação dos fitocromos, ou pela redução na absorção de água e nutrientes, em virtude da diminuição no sistema radicular (Corsi \& Nascimento Jr., 1986).

Simon \& Lemaire (1987) estudaram o efeito das doses de nitrogênio $40,80,120$, e $160 \mathrm{~kg} \mathrm{ha}^{-1}$ no estabelecimento de Italian ryegrass. Observaram número total de perfihos por planta de 7,$52 ; 8,06 ; 8,89$ e 9,53 e de 11,99; 10,$75 ; 12,86$ e 12,0 para as doses de nitrogênio de 40,80,120, e $160 \mathrm{~kg} \mathrm{ha}^{-1}$, numa primeira e segunda avaliações, respectivamente. O efeito do nitrogênio no número de perfilhos por planta foi efetivo na fase inicial do crescimento $e$ esteve relacionado ao $\mathrm{IAF}$, tendo o efeito do nitrogênio desaparecido na' 
medida que o IAF aumentou. Segundo os autores a proporção de luz entre vermelho e vermelho distante ao nível da base dos perfilhos tem um efeito no controle do perfilhamento e na medida que o IAF aumenta o perfilhamento diminui e a elongação foliar pode aumentar. Avaliando diretamente a relação entre IAF e perfilhamento verificaram um aumento no perfilhamento em função do aumento nos valores de IAF, a qual atinge um platô a valores de 3 ou 4, após o que a taxa de perfilhamento diminui. Esse modelo de resposta foi semelhante para todas as doses de nitrogênio. Para pastagens estabelecidas de festuca os autores relataram o efeito das doses de nitrogênio 0 e $60 \mathrm{~kg} \mathrm{ha}^{-1}$ em relação ao conceito de "sítio de preenchimento", a partir do valor de referência para esta variável de 0,48. Constataram que plantas adubadas atingiram o valor de referência a um IAF maior do que 2,5, enquanto que nas plantas não adubadas esse valor de referência correspondeu a valores de IAF menores que 2,0 .

Wilman \& Pearse (1984) observaram um aumento tanto no número de novos "sítios de perfilhamento" como no número de novos perfilhos emergindo em função do incremento nas doses de nitrogênio de 0 para 66 e para $132 \mathrm{~kg} \mathrm{ha}^{-1}$ em pastagens de azevém. O número de novos perfilhos emergindo/perfilho/semana aumentou de 0,05; 0,27 e 0,38 e o número de novos 'sítios"/perfilho/semana variou de 0,52; 0,68 e 0,76, para as respectivas doses de nitrogênio. Verificaram também um aumento no número de perfilhos (perfilhos por 0,1 $\mathrm{m}^{-2}$ ) de 844 para 988 e 1076 no periodo de verão e 812 para 1102 e 1270 na primavera, e na taxa de aparecimento de perfilhos de 0,05; 0,27 e 0,38 com as doses 0; 66 e $132 \mathrm{~kg} \mathrm{ha}^{-1}$, respectivamente.

McKenzie (1988) estudou o efeito de doses de nitrogênio de 120, 240, 360, 480, 600 e $720 \mathrm{~kg} \mathrm{ha-1}$ ano $^{-1}$ no perfilhamento de azevém. Verificou que a densidade total dos perfilhos variou de 3500 perfilhos $\mathrm{m}^{-2}$ na dose de nitrogênio de $120 \mathrm{~kg} \mathrm{ha}^{-1} \mathrm{ano}^{-1}$ para 17800 perfilhos $\mathrm{m}^{-2}$ na dose de $600 \mathrm{~kg} \mathrm{ha}^{-1} \mathrm{ano}^{-1}$, tendo os aumentos ocorridos até a dose de $480 \mathrm{~kg} \mathrm{ha}^{-1} \mathrm{ano}^{-1}$. 
Em relação aos perfilhos reprodutivos descreveu variação de 6 perfilhos $m^{-2}$ na dose de nitrogênio de $600 \mathrm{~kg} \mathrm{ha-1}$ ano-1 e 27 perfilhos $\mathrm{m}^{-2}$ na dose de nitrogênio de $480 \mathrm{~kg} \mathrm{ha}^{-1} \mathrm{ano}^{-1}$. Doses de nitrogênio mais elevados que $240 \mathrm{~kg}$ $\mathrm{ha}^{-1} \mathrm{ano}^{-1}$ promoveram o desenvolvimento de perfilhos reprodutivos, enquanto que doses além de $600 \mathrm{~kg} \mathrm{ha}^{-1}$ ano-1 $^{-1}$ deprimiram o desenvolvimento de perfilhos reprodutivos.

Herling et al. (1991) constataram efeito significativo das doses de nitrogênio no número de perfilhos basilares em capim-setária. Apresentaram os valores de 11,49; 14,74 e 15,06 perfilhos/vaso para as doses de nitrogênio de $0,80,160 \mathrm{~kg} \mathrm{ha}^{-1}$, respectivamente, com os dois últimos valores de perfilhamento estatisticamente semelhantes. Na análise realizada 10 dias após o corte (rebrota) a melhor resposta de 21,95 perfilhos/vaso foi obtida com a dose de nitrogênio de $160 \mathrm{~kg} \mathrm{ha}^{-1}$, que diferiu estatisticamente dos valores 16,65 e 19,96 perfilhos/vaso, observados nas doses de nitrogênio de 0 e $80 \mathrm{~kg} \mathrm{ha}^{-1}$, respectivamente. Em relação ao número de perfilhos laterais houve efeito significativo da presença do nitrogênio em relação à ausência, tendo sido alcançados os valores de 8,$75 ; 10,59$, e 11,31 para as doses de nitrogênio 0 , 80 e $160 \mathrm{~kg} \mathrm{ha}^{-1}$, respectivamente.

Cecato et al. (1994) estudaram o capim-Aruana em um Latossolo Vermelho-Escuro nas doses de nitrogênio 0,100 e $200 \mathrm{~kg} \mathrm{ha}^{-1}$, e avaliaram duas formas de aplicação, com a primeira constando de um aplicação única após o corte e a segunda com as doses de nitrogênio divididas entre o corte e 15 dias após. Não foi observado efeito significativo no perfilhamento da combinação doses e época de aplicação de nitrogênio.

Hoffman et al. (1995) avaliaram o efeito da aplicação do nitrogênio no crescimento do capim-braquiária (Brachiaria decumbens) e capim-colonião (Panicum maximum) utilizando as doses de 0; 100; 200; $300 \mathrm{e}$ 500 $\mathrm{mg} \mathrm{kg}^{-1}$ de solo, sendo cada dose subdividida em 1/3 do plantio, 1/3 aos 15 dias e 1/3 aos 30 dias após a emergência. No primeiro corte verificaram que 0 
máximo do perfilhamento de 13,9 e 3,8 perfilhos/planta para braquiária e colonião, respectivamente, ocorreu nas doses de nitrogênio 376 e $410 \mathrm{mg} \mathrm{kg}^{-1}$ de solo, enquanto os máximos valores de produção de matéria seca da parte aérea foram encontrados nas doses de nitrogênio de 342 e $338 \mathrm{mg} \mathrm{kg}^{-1}$ de solo. Assim, para os capins braquiária e colonião as doses de nitrogênio no solo para os máximos de perfilhamento foram mais elevadas que as necessárias para maximizar a produção de matéria seca da parte aérea.

Harris et al. (1996) observaram um acréscimo na densidade dos perfilhos em azevém de 4072 para 6295 e 6673 perfilhos $\mathrm{m}^{-2}$ para as doses de nitrogênio de 0; 200 e $400 \mathrm{~kg} \mathrm{ha}^{-1}$, respectivamente. A aplicação de nitrogênio também resultou em incremento no número de perfilhos por planta, observando-se 3,37; 4,10 e 4,26 perfilhos nas doses de nitrogênio de 0; 200 e $400 \mathrm{~kg} \mathrm{ha-1}$, respectivamente.

Paulino et al. (1997) estudaram o efeito de doses de nitrogênio $(0,50$ e $150 \mathrm{~kg} \mathrm{ha}^{-1}$ ) no perfilhamento do Tifton 85 e verificaram incrementos lineares no número de perfilhos em função das doses de nitrogênio.

A contribuição dos perfilhos para produção das pastagens pode ser discutida sob os aspectos de densidade de perfilhos (número de perfilhos/área) e peso de perfilhos. Segundo Corsi \& Nascimento Jr. (1986) a densidade dos perfilhos é mais importante que o peso dos perfilhos, enquanto não há uma competição severa entre eles, ou seja, enquanto a planta forrageira é capaz de interceptar grande parte da luz incidente. De acordo com a plasticidade fenotípica, uma relação inversa existe entre densidade e peso de perfilhos, denominada compensação tamanho e densidade de perfilhos (Chapman \& Lemaire, 1993). Em pastagens submetidas a baixas alturas de pastejo a otimização do índice de área foliar é promovida por uma maior densidade populacional de perfilhos menores em relação ao pastejo realizado a uma altura maior, onde uma menor densidade populacional de perfilhos maiores ocupa esse papel ( Mathew et al., 1999). Sbrissia et al. (1999) estudaram o 
perfilhamento do Tifton 85 mantido a alturas de pastejo de 5, 10, 15 e $20 \mathrm{~cm} \mathrm{e}$ observaram uma diminuição no número de perfilhos $\mathrm{m}^{-2}$ e acréscimo no peso de perfilhos com o aumento da altura da pastagem. Os valores dessas variáveis foram de 14305; 10568; 7780 e 6819 para perfilhos $\mathrm{m}^{-2}$ e 22,8; 40,8; 84,9 e 124,0 mg/perfilho para as alturas $5,10,15$ e $20 \mathrm{~cm}$ respectivamente.

Boggiano et al. (1999) testaram o efeito da fertilização com nitrogênio $\left(0,30,100,170\right.$ e $\left.200 \mathrm{~kg} \mathrm{ha}^{-1} \mathrm{ano}^{-1}\right)$ associado à niveis de disponibilidade de forragem para os animais na densidade e no peso de perfilhos em Paspalum notatum. O máximo de densidade de perfilhos de 5052 perfilhos $\mathrm{m}^{-2}$ predita pelo modelo quadrático foi obtida com nitrogênio em $130 \mathrm{~kg} \mathrm{ha}^{-1}$ ano-1 e disponibilidade de forragem de $4,2 \%$, observando-se que a densidade de perfilhos aumentou com o incremento nas doses de nitrogênio a baixos níveis de disponibilidade de forragem, mas foi reduzido a altos níveis dessa disponibilidade. O peso dos perfilhos aumentou nos níveis mais altos de disponibilidade de pastagem e doses de nitrogênio. O máximo valor de peso de perfilho estimado para o modelo quadrático foi de $80,8 \mathrm{mg}$ para a dose de nitrogênio 163 nitrogênio $\mathrm{kg} \mathrm{ha}^{-1} \mathrm{ano}^{-1}$ e disponibilidade de pastagem de $12,8 \%$. Verificaram um efeito compensatório entre densidade e peso de perfilhos e entre os efeitos de disponibilidade de forragem e dose de nitrogênio para a densidade de perfilhos. De acordo com os autores a baixos níveis de disponibilidade de forragem o nitrogênio é usado para acréscimo na densidade e peso de perfilhos e sob alta disponibilidade de forragem, com o ambiente sombreado, o nitrogênio é usado para aumentar o peso de perfilhos, ficando clara a característica de plasticidade desta forrageira

Wilman \& Pearse (1984) constataram efeito das doses de nitrogênio no peso dos perfilhos e este efeito foi ampliado pelo aumento no intervalo entre cortes. Os valores observados foram de 0,8; 4,3 e 7,9 mg/perfilho, com 
comprimento final da lâmina foliar de 6,$5 ; 12,1$ e $16,7 \mathrm{~cm}$, quando as doses de nitrogênio foram de 0; 66 e $132 \mathrm{~kg} \mathrm{ha}^{-1}$.

\subsection{Nitrogênio e crescimento das folhas}

A determinação da área foliar constitui-se numa ferramenta importante nos estudos de nutrição e adubação nitrogenada em plantas de forrageiras, podendo a resposta da planta em produção ser avaliada através deste parâmetro. A área da lâmina foliar pode ser medida através de equipamento integrador de área foliar que permite leitura diretamente nas plantas (modelos portáteis) ou em folhas destacadas. Quando se deseja manter intacta a biomassa das plantas essa avaliação pode ser feita ainda de uma maneira indireta. Medidas lineares de comprimento e de largura da lâmina foliar são tomadas diretamente nas folhas e a área obtida pelo produto destas medidas é corrigida por um fator de correção de área foliar, obtendo-se então a área real da lâmina foliar.

O fator de correção de área foliar é obtido experimentalmente a partir da relação entre a área real da lâmina foliar e essa área calculada diretamente pelo produto entre as medidas de comprimento e de largura. Em termos de plantas forrageiras esse fator foi determinado para o capim-Marandu (Brachiaria brizantha) cultivado em doses de nitrogênio $(0,21,63,105,210$ e $420 \mathrm{mg} \mathrm{L}^{-1}$ ) em solução nutritiva. O valor médio obtido foi de 0,835 e não foi observado efeito significativo $(P>0,05)$ do nitrogênio (Schiavuzzo et al., 1998a).

O crescimento da folha é um dos parâmetros a ser avaliado quanto ao efeito do nitrogênio em pastagens. O suprimento de nitrogênio influencia a produção da forragem principalmente através do seu efeito no tamanho da folha, o que ocorre tanto nas plantas individualmente como ao nível do dossel (Whitehead, 1995). O nitrogênio afeta a expressão das variáveis morfogenéticas básicas ao nível de perfilho sob diversos aspectos, entre os 
quais se inclui o aumento na taxa de elongação da folha (Cruz \& Boval, 1999). Desde que a produtividade da forrageira é frequentemente proporcional ao desenvolvimento da área foliar, a sensitividade do crescimento da folha ao suprimento do nitrogênio é de considerável importância. (Fricke et al., 1997).

Cruz \& Boval (1999) abordaram a questão do efeito do nitrogênio em espécies de forrageiras cespitosas e estoloniferas, separadamente. Segundo os autores em plantas cespitosas o tamanho final da folha é aumentado pela disponibilidade de nitrogênio e esse efeito se dá através de dois processos. Primeiramente, em filocrono constante, na qual o maior tamanho da lâmina foliar resulta da maior taxa de expansão da folha induzida pelo nitrogênio. Por outro lado, em filocrono incrementado pelo aumento no comprimento da bainha, a qual é influenciada pela disponibilidade de nitrogênio, à medida que novas folhas aparecem. Em espécies estoloniferas, após um curto periodo de crescimento da folha, a alta disponibilidade de nitrogênio intensifica a elongação dos estolões (hastes). Como consequência a taxa de aparecimento de folha sofre aumento e o tamanho da lâmina foliar torna-se menor em direção ao ápice do estolão. A menor resposta na taxa de expansão foliar pelas estoloniferas explica-se pela competição por assimilados, os quais ocorrem entre os dois sitios de elongação ativos nessas plantas (os estolões e as folhas).

Segundo Dale (1988) o crescimento e a morfogênese do primórdio e da lâmina foliar em emergência estão intimamente associados com os processos de divisão e expansão celulares. Volenec \& Nelson (1983) estudaram a resposta de festuca ao nitrogênio e verificaram aumentos da ordem de $89 \%$ para taxa de expansão foliar, de $90 \%$ no número de células epidérmicas maduras, de $62 \%$ no número de células por meristema intercalar, e $22 \%$ na taxa de elongação celular quando a dose de nitrogênio passou de 22 para $336 \mathrm{~kg} \mathrm{ha}^{-1}$. 
Pearse \& Wilman (1984) constataram que a taxa de expansão foliar de azevém aumentou de 4,2 para 8,3 e $12,1 \mathrm{~mm}$ perfilho ${ }^{-1}$ dia $^{-1}$ quando foi submetido a doses de nitrogênio $0 ; 66 \mathrm{~kg} \mathrm{ha}^{-1}$ e $132 \mathrm{~kg} \mathrm{ha}^{-1}$, respectivamente.

Maan et al. (1989) estudaram doses de nitrogênio de 40, 80, 160 e $320 \mathrm{mg} \mathrm{L}^{-1}$, em solução nutritiva e também datas de semeadura no crescimento das folhas de cevada (Hordeum vulgare). Ocorreu significância da interação entre esses fatores na taxa de expansão das folhas, sendo que a maior resposta ao nitrogênio foi obtida quando a semeadura foi realizada nos meses de abril e junho. Os valores observados, aproximados, foram 0,6 e $1,45 \mathrm{~mm} /{ }^{\circ} \mathrm{C}$ por dia para semeadura em junho e 1,65 e $0,95 \mathrm{~mm} /{ }^{\circ} \mathrm{C}$ por dia para semeadura em setembro, quando as doses de nitrogênio foram 40 e $320 \mathrm{mg} \mathrm{L}^{-1}$, respectivamente. Relataram também um aumento na área da lâmina foliar com as doses de nitrogênio e de acordo com a posição das folhas na haste principal, os quais variaram com a data de semeadura. A quinta folha posicionada na haste apresentou, em geral, uma área foliar maior, exceto nas mais baixas doses de nitrogênio. Na semeadura realizada em junho e abril a área da lâmina das folhas 4 e 5 aumentaram com as doses de nitrogênio até a mais alta dose, e considerando os meses de março e setembro, embora as folhas apresentassem tamanho maior, houve uma menor resposta ao nitrogênio para doses maiores que $160 \mathrm{mg} \mathrm{L}^{-1}$. A análise de regressão mostrou que a variação na taxa de expansão da folha foi responsável por $88 \%$ da variação no comprimento final da folha 5 . Em um segundo experimento foi demonstrado que um aumento na taxa de expansão foliar foi proporcional até um conteúdo de nitrogênio na folha de $2,5 \mathrm{mg} / \mathrm{folha}$.

Andrews et al. (1991) avaliaram os efeitos do nitrogênio no crescimento das quatro primeiras folhas da haste principal de seis espécies de gramineas de pastagem, sob as doses de nitrato que variaram de 0,5 a 5,0 mol $\mathrm{m}^{-3}$. Foram observadas diferenças na resposta entre as espécies estudadas, obtendo-se para festuca (Festuca arundinacea) os valores de 9,6 e 12,8 
$\mathrm{mm} /$ dia para taxa de expansão máxima; 6,4 e $8,5 \mathrm{~mm} /$ dia para taxa de expansão média; 13,5 e 10,8 dias para duração do crescimento; 85 e 86 mm para comprimento final da folha e 124 e $182 \mathrm{~mm}^{2}$ área final da folha. Para azevém os valores respectivos foram 14,8 e 13,4 mm/dia; 9,8 e 8,7 mm/dia; 9,6 e 10,4 dias; 91 e $90 \mathrm{~mm}$; 132 e $176 \mathrm{~mm}^{2}$.

Gastal et al. (1992) determinaram a taxa de expansão da folha em festuca em resposta ao nitrogênio e à temperatura. As doses de nitrogênio variaram de 0 até $200 \mathrm{~kg} \mathrm{ha}^{-1}$ na primavera e de 0 até $160 \mathrm{~kg} \mathrm{ha}^{-1}$ no verão. Para esses periodos a taxa de expansão foliar variou de 2 a 28 $\mathrm{mm} /$ perfilho.dia de acordo com a dose de nitrogênio e a data de medição, sendo que para um determinado dia, a taxa de expansão foliar na mais elevada dose de nitrogênio foi de 3 a 4 vezes maior que aquela encontrada na mais baixa dose de nitrogênio.

Bélanger (1998) pesquisou as caracteristicas morfogenéticas de Phleum pratense submetido a doses de nitrogênio $\left(0 ; 72 ; 140\right.$ e $210 \mathrm{~kg} \mathrm{ha}^{-1}$ antes do início de crescimento de primavera e 0; 60; 120 e $180 \mathrm{~kg} \mathrm{ha}^{-1}$ após desfolha no verão) e constatou efeito positivo do suprimento desse nutriente na taxa de expansão foliar. Quando o nitrogênio não foi aplicado, a taxa de expansão foliar foi aproximadamente $40 \%$ da taxa máxima, nos períodos de primavera e verão. O componente linear foi significativo para a maior parte das observações na primavera e quadrático no verão, quando maiores valores de taxa de expansão e a máxima taxa de expansão foram atingidos, caracterizando um efeito da temperatura nos ciclos de crescimento. Os mínimos e máximos valores para taxa de expansão na primavera e no verão foram de 7,6 e 39,8 mm/perfilho.dia e 20,7 e 78,0 mm/perfilho.dia, respectivamente.

Pinto et al. (1994b) não obtiveram efeito significativo das doses nitrogênio de 100 e $300 \mathrm{mg} \mathrm{kg}^{-1}$ de solo na taxa de expansão da área foliar do perfilho principal, na taxa de expansão da área foliar das folhas 9,10 e 11 do 
perfilho principal, na taxa de alongamento da folhas, nos capins guiné e setária, (Setária ancepts) considerando o período de 17 a 38 dias após emergência.

\subsection{Estimativa do teor de clorofila em valor SPAD}

O estado nutricional das plantas forrageiras, em termos de nitrogênio, tem sido comumente avaliado através da determinação da concentração de nitrogênio na parte aérea ${ }^{\infty}$ comparando-se em seguida com valores de referência (Werner et al.,1996 ). Uma outra possibilidade de avaliação, por um método não-destrutivo e indireto, é através da estimativa da quantidade de clorofila presente nas folhas. O nitrogênio faz parte das moléculas de proteína (Marschner, 1995) e nas células das folhas as proteinas estão presentes em organelas como cloroplastos, e nestas associadas a pigmentos como clorofila (Lyttleton, 1973).

Baseado no uso de um índice proposto por Inada ${ }^{2}$ citado por Takebe \& Yoneyama (1989), que expressa o conteúdo de clorofila nas folhas de arroz (Oryza sativa) equipamentos portáteis podem ser utilizados como estimadores da clorofila nas folhas, entre os quais o SPAD 501 (Takebe \& Yoneyama, 1989) e SPAD-502 (Wood et al., 1992). Para medir a coloração verde de uma folha com SPAD-501, um pedaço de folha é inserido no equipamento e recebe radiação emitida por uma lâmpada de xenon. A luz transmitida é separada nas regiões vermelho e infra-vermelho do espectro de luz, e a diferença em absorbância da luz transmitida nestas áreas é expressa no visor do equipamento em uma faixa que varia de 0 a 80 (Takebe \& Yoneyama, 1989).

A quantificação da clorofila e o uso dos equipamentos portáteis SPAD (Soil Plant Analysis Development, Minolta Co.) na avaliação do estado

\footnotetext{
${ }^{2}$ Inada, K. Studies on a method for determining the deepnessof green color and chlorophyll content of intact crop leaves and its practical applications. I. Principles for estimating the deepness of green color and chlorophyll content of whole leaves. Proc. Crop. Sci. Soc. (Jpn.) v.32, p.157-162, 1963.
} 
nutricional de nitrogênio nas plantas está baseada nas relações obtidas experimentalmente entre a intensidade da coloração verde das folhas, a concentração de nitrogênio e a leitura SPAD observadas.

Takebe \& Yoneyama (1989) descreveram uma relação positiva entre leitura SPAD-501 e o conteúdo de clorofila nas folhas e também entre leitura SPAD-501 e a concentração de nitrogênio nas folhas de arroz. As relações foram ajustadas por um modelo linear significativo com valores de coeficiente de determinação de 0.89 a 0.96 para a primeira dessas funções e 0,81 a 0,95 para a segunda delas, sendo a variação devida a estágios de crescimento da cultura, variedade de arroz e ano de amostragem .

Takebe et al. (1990), avaliando o estágio nutricional da cultura do arroz, observaram uma relação positiva entre o conteúdo de clorofila nas folhas e a intensidade da cor verde em folhas e entre a concentração de nitrogênio nas folhas e a intensidade da cor verde em folhas. As relações foram significativas e ajustadas por modelos lineares, obtendo-se os valores de coeficiente de determinação de 0,92 e 0,90, respectivamente.

Para a cultura de milho (Zea mays) alguns estudos de calibração também foram realizados. Dwyer et al. (1991) obtiveram uma relação linear significativa entre os valores SPAD-501 e a quantidade de clorofila nas folhas de alguns hibridos de milho com $r^{2}=0,83$.

Afim de determinar a praticidade do uso das medidas de clorofila através do SPAD-502 na avaliação do estado nutricional da cultura de milho, Wood et al. (1992) observaram uma relação quadrática entre a concentração de nitrogênio no tecido e a leitura SPAD-502 quando a cultura encontrava-se no nos estágios $\mathrm{V} 10$ e no meio do florescimento, com valores de coeficiente de determinação de 0,88 e 0,90 , respectivamente. Com a cultura no meio do florescimento os máximos valores de SPAD-502, calculados a partir das regressões, foram 61,6 e 60,6 e de concentração de nitrogênio nas folhas foram 48,0 e 40,4, observados para dois anos consecutivos, respectivamente. 
Schepers et al. (1992), objetivando quantificar a relação entre concentração de nitrogênio na folha e as leituras obtidas com SPAD-502 para a produção de milho, observaram que fatores como estágio de crescimento da cultura, híbrido considerado, época de aplicação e fonte do fertilizante nitrogenado podem limitar a utilização do SPAD-502 como um substituto para determinação da concentração de nitrogênio na folha.

A relação entre a leitura SPAD e a concentração de nitrogênio na folha pode ser alterada pela massa foliar. Peng et al. (1993) estudaram um ajuste na leitura SPAD-502 em folhas de arroz através do peso específico da folha (peso da folha seca/área foliar). Considerando a folha mais superior completamente expandida, o grau de ajuste linear obtido entre a leitura SPAD502 e a concentração de nitrogênio na folha mostrou coeficiente de 0,49 e passou para 0,93 com os valores de SPAD ajustados para o peso específico da folha. Analisando a folha bandeira o valor do coeficiente de determinação foi de 0,51 para 0,87 .

Blackmer et al. (1994), cultivando híbridos de milho, observaram uma relação linear entre a concentração de nitrogênio na folha e a leitura SPAD502 , obtendo o valor para coeficiente de determinação 0,84 . Considerando o peso especifico da folha a relação com a leitura SPAD apresentou um valor para o coeficiente de determinação de 0,92. De acordo com os autores esse resultado pode ser devido a mudanças no peso específico da folha (provavelmente a espessura da folha), que influenciariam as medidas de transmitância realizadas pelo clorofilômetro.

Bullock \& Anderson (1998) avaliaram a utilização do SPAD-502 para o manejo da cultura de milho em estágios de crescimento e aplicações de fertilizantes nitrogenados. Reportaram que as leituras SPAD-502 e a concentração de nitrogênio na folha aumentaram com a dose de fertilizante nitrogenado, de acordo com modelos lineares ou quadráticos em função do estágio de desenvolvimento da cultura (V7, R1 e R4). Relataram os coeficientes 
de correlação entre leitura SPAD-502 e concentração de nitrogênio na folha de 0,33; 0;35 e 0,78 para os estágios V7, R1 e R4 da cultura, respectivamente.

Em relação a experimentos com plantas forrageiras Kantety et al (1996) pesquisaram diversos genótipos de festuca submetidos a doses de nitrogênio. Em um primeiro experimento, utilizando doses de nitrogênio de 0 a $392 \mathrm{~kg} \mathrm{ha}^{-1}$ observaram uma relação quadrática entre leitura SPAD-502 e nitrogênio aplicado, sendo um máximo de resposta da leitura do SPAD obtido com nitrogênio de $254 \mathrm{mg} \mathrm{ha-1}$. Os valores das leituras SPAD e os coeficientes de determinação diminuíram no decorrer do período de crescimento das plantas, sugerindo que a concentração de clorofila diminui e a variação aumenta à medida que as plantas se tornam mais velhas. Em um segundo experimento a campo, no qual as doses de nitrogênio variaram de 0 a $336 \mathrm{~kg} \mathrm{ha-1}$, as leituras SPAD apresentaram uma relação quadrática com a dose de nitrogênio, com valores de coeficiente de determinação variando entre 0,$97 ; 0,96$ e 0,99 em função do local amostrado, sendo que a máxima resposta do valor SPAD ocorreu na dose de nitrogênio de $306 \mathrm{~kg} \mathrm{ha}^{-1}$.

Madakadze et al. (1999) conduziram um experimento com Panicum virgatum para avaliar o potencial das leituras SPAD-502 em determinar a concentração de nitrogênio e a produção da forragem. Foram avaliadas as doses de nitrogênio de 0,75 e $150 \mathrm{~kg} \mathrm{ha}^{-1} \mathrm{ano}^{-1}$. A relação entre as leituras SPAD medidas nas folhas e concentração de nitrogênio na planta foi positiva até a concentração de nitrogênio no tecido de $9 \mathrm{~g} \mathrm{~kg}^{-1}$.

Santos (1997) trabalhou com capim-braquiária (Brachiaria decumbens cv. Basilisk) submetido a doses de nitrogênio em solução nutritiva $(0,14,42$, $126,210,294,378$ e $462 \mathrm{mg} \mathrm{L}^{-1}$ ). Verificou que os valores das leituras SPAD502 elevaram-se com o incremento do nitrogênio na solução, com ajuste ao modelo quadrático de regressão $\left(R^{2}=0,81\right.$ e 0,98 para o primeiro e segundo cortes, respectivamente). As máximas leituras SPAD (de 50,2 e 52,0) na lâmina foliar da segunda folha expandida foram encontradas nas doses de nitrogênio 
de 330 e $442 \mathrm{mg} \mathrm{L}^{-1}$. A correlação entre os valores SPAD e a concentração de nitrogênio nos componentes das plantas mostrou altos coeficientes, tanto no primeiro como no segundo corte, tendo esses coeficientes sido de 0,80 e 0,83 nas folhas emergentes, de 0,91 e 0,93 nas lâminas das folhas recémexpandidas de 0,87 e 0,74 nas lâminas das folhas maduras, de 0,90 e 0,93 nos colmos+bainhas e de 0,91 e 0,88 na parte aérea toda da braquiária. A fração lâminas de folhas recém-expandidas e os colmos+bainhas foram os componentes com mais elevados coeficientes de correlação com os teores de clorofila medidos em valor SPAD.

Colozza (1998), estudando a diagnose foliar do capim-Aruana constatou aumento nos valores SPAD-502 nas folhas emergentes, nas lâminas das folhas recém-expandidas e nas lâminas de folhas maduras em função das doses nitrogênio aplicadas ( 0 a $\left.450 \mathrm{mg} \mathrm{kg}^{-1}\right)$. Esse efeito foi representado em sua maior parte por regressões quadráticas, com coeficientes de determinação entre 0,91 a 0,97 . Os mais altos maiores valores de SPAD foram encontrados na fração lâmina de folhas recém-expandida $(39,7$ e 43,2 no primeiro e segundo corte, respectivamente), seguidos pelo observado na fração folhas emergentes (38,2 e 35,3, para o primeiro e segundo corte, respectivamente).

Paulino et al. (1998), testando quatro cultivares de Panicum maximum (Aruana, Tanzânia, Tobiatã e Vencedor), relataram uma resposta positiva às doses de nitrogênio $\left(0,80,160 \mathrm{~kg} \mathrm{ha}^{-1}\right)$ no valor SPAD-502 m. O cultivar Aruana apresentou valores de SPAD superiores (29 a 41) aos demais, os quais foram semelhante entre si (15 a 38). Teores de clorofila abaixo de 38 unidades de SPAD, segundo os autores, são indicativos de condição nutricional inadequada em nitrogênio.

Schiavuzzo et al. (1999) abordaram a influência de doses de nitrogênio em solução nutritiva $\left(0,14,42,126,210,294,378\right.$ e $\left.426 \mathrm{mg} \mathrm{L}^{-1}\right)$ na leitura SPAD-502 realizada aos 39 dias de crescimento em folhas de capim- 
Marandú. Verificaram efeito significativo $(P<0,05)$ das doses de nitrogênio na leitura SPAD-502 e esse efeito foi representado por equação de segundo grau.

Abreu (1999) cultivou os capins Tanzânia e marandu (Brachiaria brizantha ) em doses de nitrogênio $\left(0 ; 75 ; 150\right.$ e $\left.300 \mathrm{mg} \mathrm{k} \mathrm{g}^{-1}\right)$ num Latossolo Vermelho-Amarelo e detectou um efeito significativo do nitrogênio nos valores da leitura SPAD-502, em fases do crescimento da planta . Para o capimMarandu os niveis críticos de nitrogênio determinados nas lâminas de folhas recém-expandidas estiveram associados a valores de SPAD de 21,8 e 38,6 para os 14 e 28 dias de desenvolvimento, respectivamente, e de 22,0 e 34,5 associados aos 42 dias de desenvolvimento. No capim-Tanzânia os niveis críticos estiveram associados aos valores de SPAD de 41,8 e 40,4 para os 14 e 28 dias de desenvolvimento, respectivamente, e de 25,0 e 27,0 associados para os 42 dias de desenvolvimento.

O efeito da dose de nitrogênio em solução nutritiva $(14,126,210,294$ e $462 \mathrm{mg} \mathrm{L}^{-1}$ ) na leitura SPAD-502 e na concentração de nitrogênio no tecido em capim-Tanzânia foi estudado por Schiavuzzo et al. (1998b). Relataram um aumento da leitura SPAD-502 com o incremento na dose de nitrogênio na solução, sendo essa variação representada por uma função quadrática com $R^{2}=0,94$. Também apontaram um aumento da leitura SPAD com a elevação na concentração de nitrogênio no tecido, o que ocorreu segundo um modelo linear com $R^{2}=0,94$. O máximo valor de $S P A D$ foi de 47,0 , mediante o fornecimento de nitrogênio de $461 \mathrm{mg} \mathrm{L}^{-1}$.

Trabalhando com o capim-Mombaça Manarin (2000) constatou elevação nos valores de leitura SPAD em função do aumento nas doses de nitrogênio em solução nutritiva $\left(0,14,42,126,210,294,378\right.$ e $\left.426 \mathrm{mg} \mathrm{L}^{-1}\right)$ e a relação entre essas variáveis foi representada por modelos quadráticos com $R^{2}=0,93$ no primeiro crescimento e linear com $R^{2}=0,93$ no segundo crescimento. Nesse estudo, o valor SPAD correspondente ao nível crítico de nitrogênio nas 
lâminas das folhas recém-expandidas do capim-Mombaça foi de 45,0 e 42,0 unidades, no primeiro e no segundo corte, respectivamente. 


\section{MATERIAL E MÉTODOS}

Um grupo de experimentos foi conduzido com a gramínea Tifton 85 (Cynodon spp), em casa-de-vegetação pertencente ao Departamento de Solos e Nutrição de Plantas, da Escola Superior de Agricultura "Luiz de Queiroz", Universidade de São Paulo, localizada no Município de Piracicaba, Estado de São Paulo.

O estudo foi desenvolvido na forma de três experimentos, conduzidos simultaneamente e identificados como I, II e III. Os experimentos I e II foram estabelecidos em esquema fatorial $4 \times 2$, sendo avaliadas quatro doses de nitrogênio e duas épocas de aplicação de nitrogênio, com quatro repetições (totalizando 32 vasos por experimento). No experimento III foram estudadas quatro doses de nitrogênio com seis repetições, totalizando 24 vasos. O delineamento experimental para os três experimentos foi o de blocos completos ao acaso.

As doses de nitrogênio estudadas nos três experimentos foram de 0 , 80,160 e $240 \mathrm{mg} \mathrm{kg}^{-1}$ de solo e este nutriente foi suprido na forma de $\mathrm{NH}_{4} \mathrm{NO}_{3}$. As duas épocas de aplicação de nitrogênio foram imediatamente após o corte e sete dias após o corte.

O solo utilizado é classificado, de acordo com o Sistema Brasileiro de Classificação de Solos (EMBRAPA, 1999), como NEOSSOLO QUARTIZARÉNICO Órtico típico, com horizonte $A$ moderado álico fase cerrado e relevo plano (classificado antigamente como Areia Quartzosa álica) e foi coletado em uma propriedade localizada no Município de São Pedro, Estado de São Paulo, onde 
a vegetação predominante era de cerrado. Coletou-se o solo a uma profundidade de 0 a $20 \mathrm{~cm}$ e em seguida o mesmo foi secado à sombra e peneirado. $A$ análise do solo seco revelou $\mathrm{pH}$ em $\mathrm{CaCl}_{2}=3,95 ; P=1,6 \mathrm{mg} \mathrm{dm}^{-3}$; matéria orgânica $=15,9 \mathrm{~g} \mathrm{dm}^{-3} ; \mathrm{K}^{+}=0,3 ; \mathrm{Ca}^{2+}=0,6 ; \mathrm{Mg}^{2+}=0,5 ; \mathrm{H}+\mathrm{Al}=47 ; \mathrm{Al}^{3+}=7 \mathrm{e}$ soma de bases trocáveis $=1,4$ (concentrações essas expressas em $\mathrm{mmol}_{\mathrm{c}} \mathrm{dm}^{-3}$ ); CTC $=48,4$ e $\vee \%=2,89$.

A correção da acidez do solo foi baseada na elevação da saturação por bases a $60 \%$, conforme a utilizada por Palhano (1990) para Cynodon spp. A quantidade correspondente de calcário foi determinada conforme recomendado por Raij et al. (1987) e empregou-se $\mathrm{CaO}$ e $\mathrm{MgO}$ na forma de reagentes analíticos.

Sete quilogramas de solo foram colocados em sacos plásticos, aos quais foram acrescentados $2873 \mathrm{mg}$ de $\mathrm{CaO}$ e $1025 \mathrm{mg}$ de $\mathrm{MgO}$, seguindo-se uma agitação manual por cinco minutos. Cada um deles foi acondicionado em um vaso plástico e em seguida adicionou-se água deionizada até que o solo atingisse a capacidade de campo estimada. Essa operação foi realizada em 12 de dezembro de 1997, quando alguns vasos foram pesados como referência. Nos dias 20 e 27 de dezembro foram novamente pesados para cálculo de reposição de água em todos os vasos.

O plantio foi realizado em 29, 30 e 31 de janeiro de 1998. Sete mudas foram transplantadas em cada vaso, sendo cada muda formada por uma haste única, com área foliar e sistema radicular presentes. As mudas foram selecionadas quanto ao tamanho, padronizando-se o estande de plantas para todos os vasos.

Em 9 de fevereiro foi realizado um corte de uniformização nas plantas nos três experimentos, a uma altura de $4,5 \mathrm{~cm}$, em função da ocorrência de um ataque de fungos saprófitas, ocasião em que foram retiradas todas as folhas velhas presentes. Em 10 de fevereiro foi realizada uma adubação em todos os experimentos em termos de $\mathrm{mg} \mathrm{kg}^{-1}$ de solo, com 
$P=100, K=125,8$ e $N=10$, através do emprego dos reagentes analíticos $\mathrm{KH}_{2} \mathrm{PO}_{4}$ e $\mathrm{NH}_{4} \mathrm{NO}_{3}$. Em 9 de março foi efetuado outro corte de uniformização a $2,5 \mathrm{~cm}$ de altura e no dia seguinte foi realizada uma adubação com nitrogênio à base de $10 \mathrm{mg} \mathrm{kg}^{-1}$ de solo, empregando-se o produto analítico $\mathrm{NH}_{4} \mathrm{NO}_{3}$.

O período experimental teve início em 24 de março com a realização de um corte das plantas a 2,5 cm de altura, ocasião em que foram aplicadas as doses de nitrogênio de $0,80,160$ e $240 \mathrm{mg} \mathrm{kg}^{-1}$ de solo com $\circ \mathrm{NH}_{4} \mathrm{NO}_{3}$, além da adubação básica geral que se constituiu dos seguintes nutrientes, com doses (em mg kg-1 de solo) e reagentes analíticos respectivamente especificados: $\mathrm{P}=100\left(\mathrm{KH}_{2} \mathrm{PO}_{4}\right) ; \mathrm{K}=125,8\left(\mathrm{KH}_{2} \mathrm{PO} \mathrm{O}_{4}\right) ; \mathrm{S}=8\left(\mathrm{MgSO}_{4}\right) ; \mathrm{B}=0,25$ $\left(\mathrm{H}_{3} \mathrm{BO}_{3}\right) ; \mathrm{Cu}=1,00 \quad\left(\mathrm{CuSO}_{4} .5 \mathrm{H}_{2} \mathrm{O}\right) ; \mathrm{Zn}=1,00 \quad\left(\mathrm{ZnSO}_{4} \cdot 7 \mathrm{H}_{2} \mathrm{O}\right) ; \mathrm{Mo}=0,10$ $\left(\mathrm{Na}_{2} \mathrm{MoO}_{4} \cdot 2 \mathrm{H}_{2} \mathrm{O}\right)$.

Os três experimentos foram conduzidos simultaneamente e avaliados em dois periodos de crescimento das plantas, sendo o primeiro de 24 de março a 2 de maio (39 dias) e o segundo de 3 de maio a 13 de junho de 1998 (41 dias). Cada início de crescimento foi marcado pelo corte das plantas e pelo fornecimento de nitrogênio, nas doses e épocas respectivas a cada tratamento. Após o primeiro corte foram realizadas adubações de reposição de nutrientes, cujas doses em $\mathrm{mg} \mathrm{kg}^{-1}$ solo e os respectivos reagentes analíticos foram: $P=20,0 ; K=58,4$ e $S=13,7\left(\mathrm{KH}_{2} \mathrm{PO} 4\right.$ e $\left.\mathrm{K}_{2} \mathrm{SO}_{4}\right)$.

\subsection{Experimento 1}

Nesse experimento foi determinada a relação entre área da lâmina foliar determinada no medidor portátil e a área obtida pela multiplicação das medidas de comprimento pela largura da lâmina foliar. Essa relação é identificada como fator $F$.

Foram realizadas duas determinações, uma no primeiro e outra no segundo período experimental ( 8 de abril e 22 de maio), quando as plantas 
tinham 15 e 20 dias de crescimento, respectivamente. Em cada determinação foram coletadas lâminas foliares de tamanho médio, de plantas distintas em cada vaso, em número de dez na primeira avaliação e seis na segunda avaliação. A coleta foi sempre às $6: 30$ horas, quando as folhas se encontravam túrgidas. As lâminas foliares foram ensacadas individualmente e procedeu-se à medição do comprimento e da largura, sendo esta última determinada na sua parte mais larga. A determinação da área da lâmina foliar foi realizada no medidor portátil Modelo LI-3000 A e o fator $(F)$ foi obtido pela relação entre área determinada no medidor / comprimento x largura da lâmina foliar.

\subsection{Experimento II}

Durante o periodo experimental as plantas foram avaliadas nas suas respostas fisiológicos de crescimento nos parâmetros perfilhamento e crescimento de folhas e ao final desse periodo tratou-se de avaliar a produção de matéria seca da parte aérea e das raízes, a relação como+bainha/lâmina foliar e concentração de nitrogênio no tecido vegetal.

$\mathrm{Na}$ avaliação do perfilhamento foi utilizada a técnica dos perfilhos marcados com fio de arame colorido (Davies, 1981) e foi conduzida do início ao término de cada período de crescimento. Após o corte das plantas todos os perfilhos existentes no vaso foram marcados com anéis de uma única cor, sendo que no primeiro periodo de crescimento esta marcação deu-se no dia do corte e no segundo período nos quatro primeiros dias de crescimento. Posteriormente, a cada dois dias, os perfilhos emergidos eram marcados com anéis de uma cor diferente, correspondente ao dia de avaliação. Foram marcados perfilhos da base e laterais (ou aéreos) indistintamente. No momento do corte todos os anéis foram retirados e separados pela cor correspondente a cada data de marcação. 
O perfilhamento do Tifton 85 foi avaliado em termos de número inicial de perfilhos (correspondente ao número de perfilhos presentes no início de cada período experimental), número parcial de perfilhos (correspondente aos perfilhos que surgiram durante o periodo experimental) e numero total de perfilhos (que corresponde a soma dos perfilhos inicial e parcial). O peso dos perfihos (mg/perfilho) foi obtido pela relação entre produção de matéria seca da parte aérea em cada corte e o número total de perfilhos.

O crescimento das folhas foi avaliado em uma folha por planta, em quatro plantas distintas em cada vaso, iniciando-se em duas épocas sequenciais, dentro de cada período de crescimento. No primeiro crescimento a primeira e segunda avaliações foram iniciadas, respectivamente, nos dias $3 \mathrm{e}$ 11 de abril, enquanto que no segundo crescimento, as denominadas terceira e quarta avaliações, tiveram início em 13 e 19 de maio. A folha mais nova de cada planta foi definida como folha padrão de medição. A folha imediatamente anterior a esta era marcada com tinta como referência em relação à folha padrão de medição. As folhas foram observadas a cada dois dias até sua completa expansão, identificado pelo aparecimento da lígula (Andrews et al., 1991), quando a área final foi determinada. Nessa avaliação o comprimento da lâmina foliar foi medido entre sua ponta até a lígula e a largura da lâmina foi medida na sua parte mais larga. A multiplicação do comprimento pela largura permitiu estimar a área da lâmina foliar, que multiplicado pelo fator de correção (F) forneceu a área real da lâmina foliar. Avaliou-se o comprimento e a área final da lâmina foliar.

A produção da forrageira foi avaliada nos dois crescimentos, sendo 0 primeiro corte realizado em 2 de maio, a uma altura de $2,5 \mathrm{~cm}$ do solo, e o segundo em 13 de junho, com o corte ao nível do solo. O material coletado (parte aérea no primeiro e no segundo corte, e raízes ao final do segundo corte) foi levado para estufa com ventilação forçada, a temperatura de $65^{\circ} \mathrm{C}$, por 72 horas. 
Após a secagem, o material relativo à parte área do primeiro e do segundo corte foi separado nas frações colmotbainha e lâmina foliar. A partir dos resultados de pesagem dessas frações, foi possivel calcular a relação colmo+bainha / lâmina foliar.

A concentração de nitrogênio total nos tecidos da parte aérea colhida em ambos os cortes e das raizes foi determinada conforme metodologia descrita por Sarruge \& Haag (1974).

\subsection{Experimento III}

Neste experimento foi determinada a relação entre as unidades de leitura SPAD e concentração de nitrogênio total $\left(\mathrm{g} \mathrm{kg}^{-1}\right)$ da lâmina foliar do capim-Tifton 85. Foram realizadas duas determinações, a primeira em 19 de abril e a segunda em 31 de maio de 1988, correspondendo aos dois períodos de crescimento das plantas. Na determinação do teor de clorofila nas folhas foi utilizado o Chlorophyll Meter SPAD-502 (Soil Plant Analysis Development), que fornece leituras em valor correspondente à quantidade de clorofila na amostra. As leituras do valor SPAD foram realizadas no terço médio da lâmina foliar da segunda folha expandida a partir do ápice das plantas (Santos, 1997), tomando-se uma folha por planta em dez plantas distintas por vaso. Seguindose à leitura SPAD tratou-se de coletar a lâmina foliar correspondente às segundas folhas completamente expandidas das plantas de cada vaso e nestas determinada a concentração de nitrogênio total, conforme metodologia descrita por Sarruge \& Haag (1974).

\subsection{Análise estatística}

Foi realizada análise de variância para verificar o efeito significativo $(P<0,05)$-de doses e de épocas de aplicação de nitrogênio nos parâmetros de 
crescimento avaliados. O efeito da dose de nitrogênio foi ajustado por modelos linear e quadrático e o efeito da época foi avaliado através do teste de Tukey $(P<0,05)$. Foi utilizado o programa SAS for WINDOWS versão 6,11. 


\section{RESULTADOS E DISCUSSÃO}

\subsection{Experimento I}

A análise de variância mostrou efeito significativo $(P<0,05)$ das doses de nitrogênio na determinação do fator de correção de área foliar. Esses efeitos foram representados por regressão quadrática e linear, respectivamente no primeiro e segundo crescimentos (Figura 1). Com a elevação no suprimento de nitrogênio houve uma diminuição no valor do fator que atingiu um mínimo estimado de 0,77 na dose de nitrogênio de $154 \mathrm{mg} \mathrm{kg}^{-1}$ de solo, no primeiro crescimento da gramínea. A diminuição observada no fator $F$, com o aumento das doses de nitrogênio, indica um efeito mais acentuado no crescimento da lâmina foliar no sentido longitudinal que no sentido transversal.

O valor máximo estimado para o fator de 0,83 , em ambos os crescimentos do Tifton 85 na não aplicação de nitrogênio, está muito próximo ao valor de 0,835 obtido para o capim-Marandu por Schiavuzzo et al. (1998a). Esses autores não constataram variação nesse fator em função das doses de nitrogênio. O efeito do nitrogênio no crescimento das folhas, em termos de comprimento e de área foliares, depende em alto grau da espécie considerada, como foi verificado por Andrews et al. (1991). Para Phalaris aquatica verificouse a variação de 69 e $76 \mathrm{~mm}$ para comprimento e de 160 e $212 \mathrm{~mm}^{2}$ para área foliar nas doses de nitrogênio de 0,5 e $5,0 \mathrm{~mol} \mathrm{~m}^{-3}$, respectivamente; para azevém a variação observada foi de 91 e $90 \mathrm{~mm}$ e de 132 e $176 \mathrm{~mm}^{2}$ para comprimento e área foliares, respectivamente, na mesma condição experimental. Valores inferiores obtidos para o capim-Tifton 85 em relação à 
braquiária Marandu são provavelmente devidos a um desenho diferente de lâmina foliar, ou a uma largura proporcionalmente maior em relação ao comprimento observado para essa braquiária.

A partir dos modelos de regressão apresentados estimaram-se os valores do fator $F$ de 0,$83 ; 0,79 ; 0,77$ e 0,79 para o primeiro crescimento $e$ 0,$83 ; 0,82 ; 0,81$ e 0,80 para o segundo crescimento, em função das doses de nitrogênio de 0; 80; 160 e $240 \mathrm{mg} \mathrm{kg}^{-1}$ de solo, respectivamente. Estes valores foram utilizados para cálculo da área foliar, a partir das medidas de comprimento e largura tomadas diretamente nas plantas, para cada tratamento e período de crescimento.

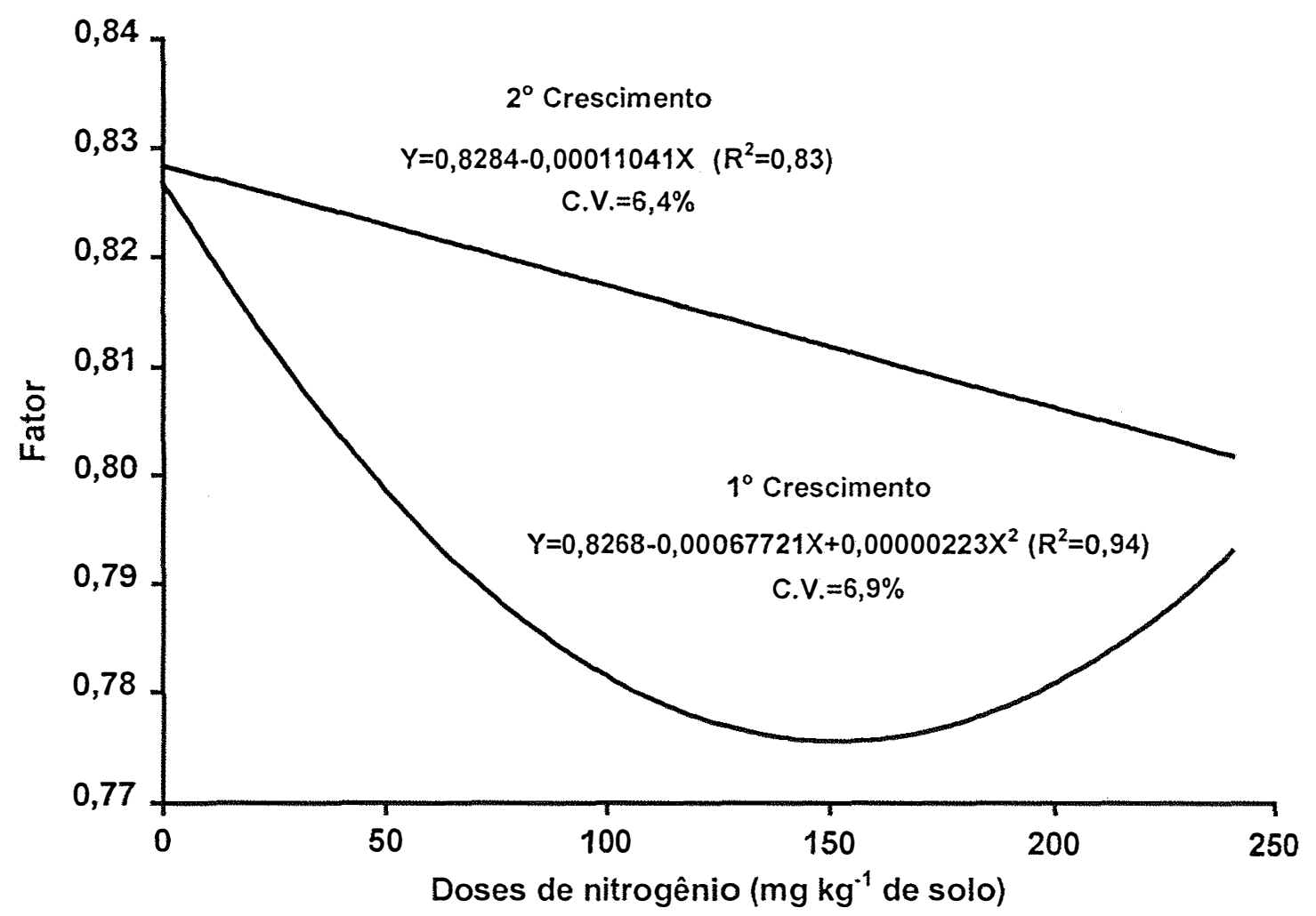

Figura 1 - Fator de correção de área foliar para o capim-Tifton 85, no primeiro e no segundo crescimentos, em função das doses de nitrogênio. 


\subsection{Experimento II}

\subsubsection{Produção de matéria seca da parte aérea e raízes}

A análise de variância mostrou efeitos significativos $(P<0,05)$ das doses de nitrogênio na produção de matéria seca da parte aérea no primeiro e no segundo cortes. Os resultados dessas produções da parte aérea mostraram ajustes a modelos quadráticos de regressão (Figura 2).

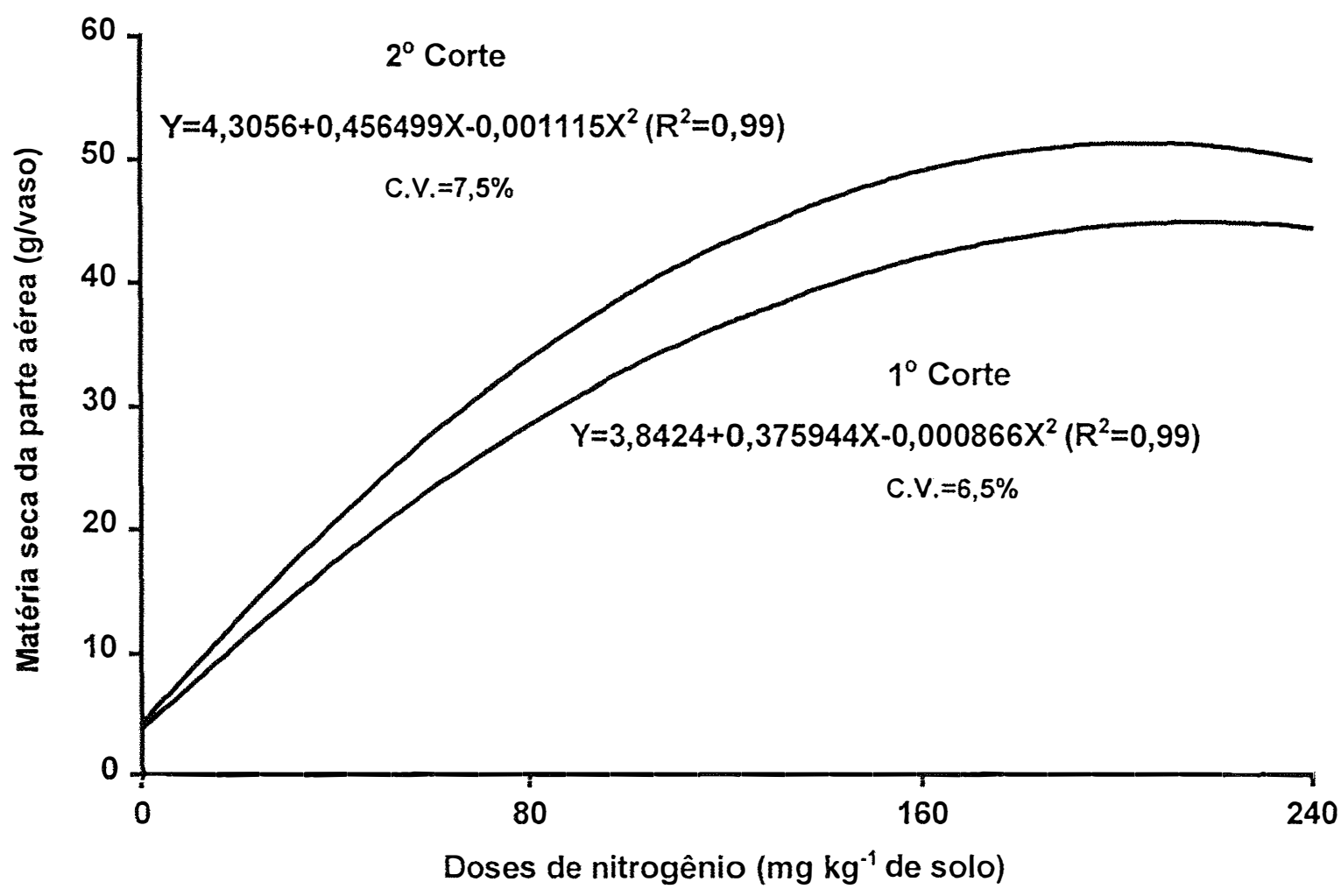

Figura 2 - Produção de matéria seca da parte aérea do capim-Tifton 85 , no primeiro e segundo cortes, em função das doses de nitrogênio.

Os máximos valores estimados de produção de matéria seca da parte aérea $(44,64$ e $51,03 \mathrm{~g} / \mathrm{vaso})$ foram obtidos com o suprimento de nitrogênio em 217 e $205 \mathrm{mg} \mathrm{kg}^{-1}$ de solo, no primeiro e no segundo cortes, respectivamente. 
Experimentos realizados no Brasil tem mostrado que o Tifton 85 é uma forrageira responsiva à adubação nitrogenada. Martim (1997) obteve resposta linear significativa ao nitrogênio na produção de matéria seca da parte aérea pelo Tifton 85. Observou uma variação na produção de matéria seca da ordem de 43 e $113 \%$ quando comparou as doses de nitrogênio de 20 e $180 \mathrm{~kg}$ $\mathrm{ha}^{-1}$, em termos de valores médios para os capins Tifton 85 e Coastcross. 0 máximo valor de produção alcançado pelo Tifton 85 , na máxima dose de nitrogênio de $180 \mathrm{~kg} \mathrm{ha}^{-1}$ e com potássio de $135 \mathrm{~kg} \mathrm{ha}^{-1}$ utilizadas por Martim (1997), foi inferior ao máximo obtido no presente experimento.

Paulino et al. (1997) verificaram respostas às doses de nitrogênio de 0,50 e $150 \mathrm{~kg} \mathrm{ha}^{-1}$ na produção de matéria seca da parte aérea do capim-Tifton 85 , a qual foi representada por acréscimos linear e quadrático, dependendo do período de crescimento considerado. A produção de matéria seca observada nas mais elevadas doses de nitrogênio também atingiu valor inferior aos constatados no presente estudo.

Gomes et al. (1997) obtiveram resposta às doses de nitrogênio de $0 \mathrm{e}$ de $400 \mathrm{~kg} \mathrm{ha}^{-1}$ ano $^{-1}$ na produção do Tifton 85 , com aumentos de produção da ordem de $150 \%$ para o período das águas e $23 \%$ para o período das secas.

Alvim et al. (1998) observaram efeito significativo das doses de nitrogênio de 0 a $600 \mathrm{~kg} \mathrm{ha}^{-1}$ ano $^{-1}$ na produção de matéria seca da parte aérea do capim-Tifton 85. Considerando a produção anual, com manejo entre cortes de quatro semanas na época das águas e de seis semanas na das secas, o maior incremento de produção foi observado entre a não aplicação de nitrogênio e a dose de $100 \mathrm{~kg} \mathrm{ha}^{-1}$ ano $^{-1}$, o qual atingiu $71 \%$. Os acréscimos na produção de matéria seca foram decrescentes com mais elevadas doses de nitrogênio utilizadas, o que está de acordo com a Lei de Mitscherlich para a nutrição de plantas. A máxima produção de matéria seca foi de $23,1 \mathrm{Mg} \mathrm{ha}^{-1}$, e foi atingida com o emprego da dose de nitrogênio de $600 \mathrm{~kg} \mathrm{ha}^{-1} \mathrm{ano}^{-1}$.

Alves (2000), estudando o rendimento do capim-Tifton 85 , verificou que o incremento nas doses de nitrogênio possibilitou um aumento no número 
de cortes das parcelas dentro da altura pré-estabelecida $(30,40$ e $50 \mathrm{~cm})$ para corte. Relatou um efeito linear da altura de corte e da dose de nitrogênio na produção da forragem, obtendo variação na produção de 2,78 e 19,93; 3,34 e 18,96; 5,00 e 24,22 $\mathrm{Mg} \mathrm{ha}^{-1}$ para as plantas recebendo as doses de nitrogênio 0 e $400 \mathrm{~kg} \mathrm{ha}^{-1}$, colhidas aos 30, 40 e $50 \mathrm{~cm}$ de altura respectivamente, num primeiro ano de avaliação.

No presente estudo não se constatou variação significativa $(P>0,05)$ da época de aplicação do nitrogênio após o corte, para a produção de matéria seca da parte aérea do capim-Tifton 85. Recomendações tem sido feitas para aplicação de nitrogênio imediatamente após o corte (Nabinger, 1997) ou até um máximo de cinco a sete dias após o corte, para o capim-elefante (Silva et al., 1996). Vicente-Chandler et al. (1962) obtiveram mais elevada produção quando o nitrogênio foi aplicado imediatamente após o corte, em relação à aplicação 25 dias após o corte (dentro de um período de crescimento de 60 dias). Para o capim-Tifton 85 o intervalo estudado na adubação nitrogenada foi de sete dias, bem inferior ao limite ao considerado por Vicente-Chandler et al. (1962), mas dentro do limite de tempo recomendado por Silva et al. (1996).

As plantas que não receberam nitrogênio no período inicial (zero a sete dias) podem ter utilizado suas reservas orgânicas para o crescimento. De acordo com Engels \& Marschner (1995) as plantas podem absorver nitrogênio em excesso em relação às suas necessidades atuais para crescimento e utilizar esse nitrogênio em crescimento posterior. Ourry et al. (1988) verificaram, na fase inicial da rebrota do azevém, ou nos primeiros seis dias após o corte das plantas, que a maior parte do nitrogênio presente nas folhas foi mobilizado das reservas orgânicas das raizes e da base do caule. Raizes, rizomas, base do caule e outras partes que permanecem nas plantas após a desfolha se constituem em órgãos de reservas orgânicas (Sheard, 1973), e podem suprir em nutrientes às plantas no novo crescimento.

A análise de variância mostrou efeito significativo $(P<0,05)$ das doses e das épocas de aplicação do nitrogênio após o corte na produção de matéria 
seca de raizes. A resposta às doses do nitrogênio mostrou ajuste a um modelo quadrático de regressão (Figura 3 ) com a produção máxima estimada de matéria seca de raízes $(30,22 \mathrm{~g} / \mathrm{vaso})$ obtida com fornecimento de nitrogênio de $196 \mathrm{mg} \mathrm{kg}^{-1}$ de solo.

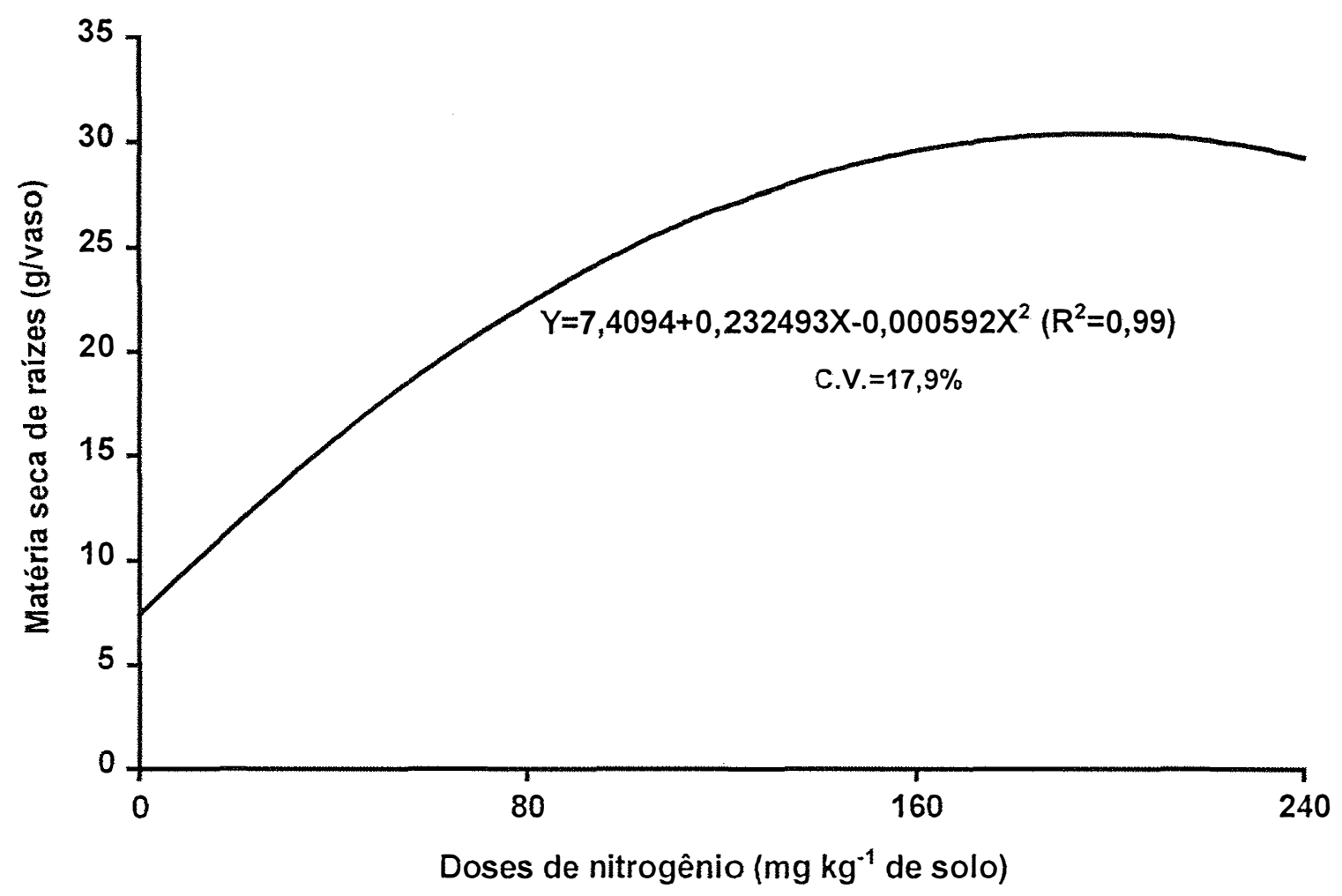

Figura 3 - Produção de matéria seca de raízes do capim-Tifton 85 , em função das doses de nitrogênio.

Uma resposta à adubação nitrogenada, segundo equação de primeiro grau, na produção de raízes do capim-Tifton 85 foi observado por Martim (1997), para as doses de nitrogênio entre 20 e $180 \mathrm{~kg} \mathrm{ha-1}$. Paulino et al. (1997) observaram aumentos lineares na produção de matéria seca de raízes em resposta ao incremento nas doses de nitrogênio de 0 para 50 e $150 \mathrm{~kg} \mathrm{ha}^{-1}$. Os máximos valores observados por esses autores para a produção de matéria seca de raízes foram inferiores ao máximo constatado neste experimento. 
A produção de matéria seca de raízes foi inferior no tratamento com adubação nitrogenada realizada sete dias após o corte das plantas, em relação àquela imediatamente após o corte, tendo sido observadas as produções de 20,65 e 23,46 g/vaso, respectivamente.

As raízes são consideradas órgãos de reserva de energia na forma de carboidratos e nitrogênio para as plantas, e particularmente para os capins bermuda o rizoma também desempenha esta função. A mais baixa produção de matéria seca de raízes, observada quando o nitrogênio foi aplicado sete dias após o corte, pode significar a utilização dessas reservas no período inicial do crescimento das plantas, em função do atraso da aplicação de nitrogênio, já que a produção de matéria seca da parte aérea não foi afetada pela época de aplicação do nitrogênio, tanto no primeiro como no segundo cortes.

\subsubsection{Relação colmo+bainha / lâmina foliar}

Foram constatados efeitos significativos das doses de nitrogênio $(P<0,05)$ na relação colmo+bainha / lâmina foliar tanto no primeiro e como no segundo corte do capim-Tifton 85 . Os resultados dessa relação apresentaram ajuste a modelos quadráticos de regressão (Figura 4).

No primeiro corte foram observados acréscimos na fração colmo+bainha/lâmina foliar na planta desde a não aplicação de nitrogênio até a relação atingir o máximo valor de 1,33, obtido na dose de nitrogênio de $147 \mathrm{mg} \mathrm{kg}^{-1}$ de solo. A partir desse ponto de máximo essa relação teve decréscimos até a mais elevada dose de nitrogênio, mas manteve sempre valor maior do que 1,00 .

No segundo corte foi observado um decréscimo na relação colmo+bainha/lâmina foliar, entre a ausência de adubação nitrogenada e a dose de nitrogênio de $178 \mathrm{mg} \mathrm{kg}^{-1}$ de solo, situação em que se constatou o valor mínimo de 1,5. Na não aplicação de nitrogênio foram encontrados valores mais altos para a relação colmo+bainha/lâmina foliar (até 2,5), o que pode estar 
associado ao fato da permanência de parte de colmos+bainhas por ocasião do primeiro corte, que se efetuou na altura de $2,5 \mathrm{~cm}$ do solo.

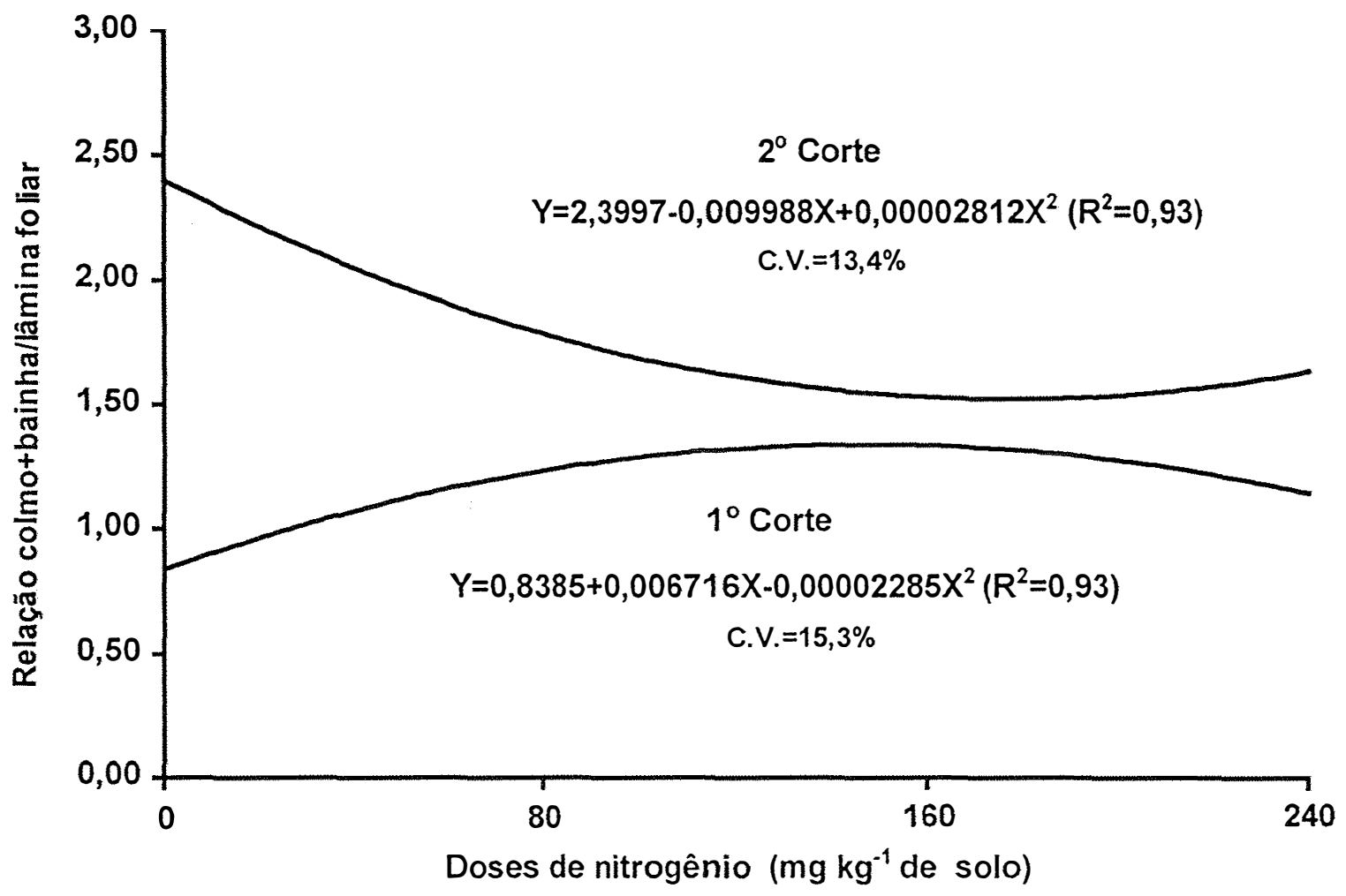

Figura 4 - Relação colmo+bainha / lâmina foliar do capim-Tifton 85 , no primeiro e no segundo cortes, em função das doses de nitrogênio.

Gomide (1996) encontrou relação folha/colmo variando entre 0,89 e 1,32 para o capim-Tifton 85 , avaliado em idades desde 14 até 42 dias de crescimento. Carnevalli et al. (1999) relataram variação de 2,8 a 3,3 nos valores de colmo+bainha/lâmina foliar para esse mesmo capim.

Martim (1997) verificou uma diminuição na relação colmo+bainha/lâmina foliar, em função das doses de nitrogênio de 20 a $180 \mathrm{~kg} \mathrm{ha-1}$ para o os capins Tifton 85 e Coastcross como resultado de um crescimento proporcionalmente maior em folhas em consequência da aplicação de nitrogênio. Os valores mais elevados para a relação haste+bainha/lâmina 
foliar observados pela autora, para o capim-Tifton 85 , estiveram entre 1,0 e 1,47 na dose mais baixa de nitrogênio.

Alves (2000) detectou significância para interação entre dose de nitrogênio e altura ao tempo de corte para a relação lâmina foliar/colmo, tendo a resposta se ajustado a uma equação de primeiro grau em função das doses de nitrogênio para a altura ao tempo de corte. As médias dos valores para relação lâmina/colmo, por corte, foram de 0,75 e 1,26; 0,95 e 1,23; 0,46 e 1,01 para plantas recebendo as doses de nitrogênio de 0 e $133 \mathrm{~kg} \mathrm{ha}^{-1}$ e colhidas ao atingirem 30,40 e $50 \mathrm{~cm}$ de altura, respectivamente.

\subsubsection{Concentração de nitrogênio no tecido vegetal}

No primeiro corte ocorreu efeito significativo $(P<0,05)$ das doses de nitrogênio na concentração de nitrogênio na matéria seca da parte aérea. Esse efeito traduziu-se em ajuste a modelo de segundo grau, como mostra a figura 5. A variação na concentração de nitrogênio no tecido esteve entre $7,84 \mathrm{e}$ 23,24 $\mathrm{g} \mathrm{kg}^{-1}$, para a amplitude das doses desse nutriente de 0 a $240 \mathrm{mg} \mathrm{kg}^{-1}$ de solo.

Hill et al. (1993) apresentaram valores de proteina bruta que variaram entre 114 a $156 \mathrm{~g} \mathrm{~kg}^{-1}$ (correspondentes a concentrações de nitrogênio de 18,24 a 24,9 $\mathrm{g} \mathrm{kg}^{-1}$ ) para o capim-Tifton 85 cultivado na Geórgia. Martim (1997), em experimento em casa-de-vagetação no Brasil, reportou valores para concentração de nitrogênio na matéria seca da parte aérea do capim-Tifton 85 oscilando entre 9,13 até $19,25 \mathrm{~g} \mathrm{~kg}^{-1}$, em função das doses de nitrogênio e de potássio, com efeito significativo e linear da dose de nitrogênio nessa concentração do nutriente. 


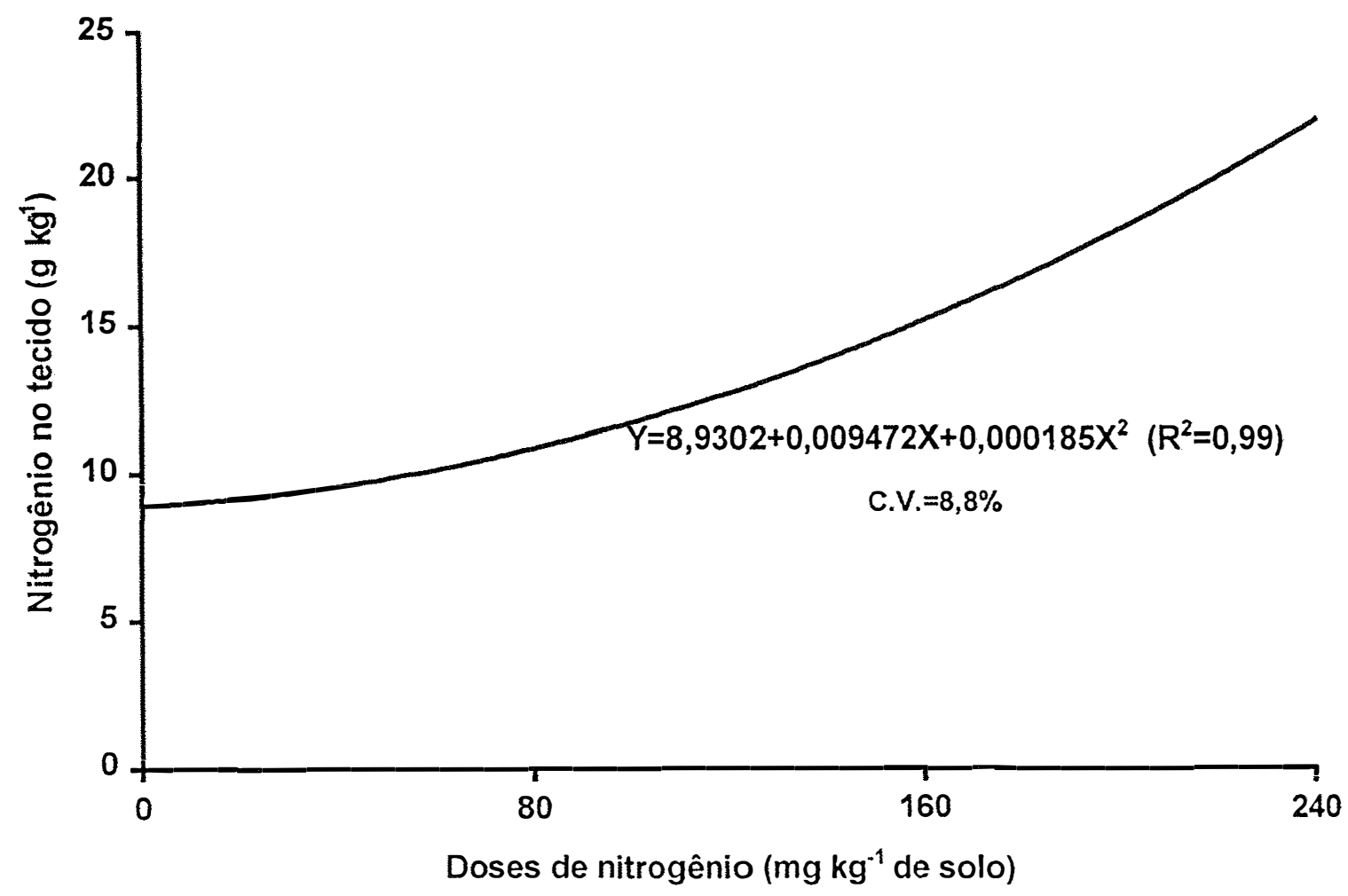

Figura 5 - Concentração de nitrogênio na matéria seca da parte aérea do primeiro corte do capim-Tifton 85 , em função das doses de nitrogênio.

Alvim et al. (1998) descreveram aumento na concentração média anual de proteína bruta (e portanto do nitrogênio total) no capim-Tifton 85 , proporcionado pelas doses de nitrogênio. Foram observados valores para proteína bruta entre 59 e $217 \mathrm{~g} \mathrm{~kg}^{-1}$ (correspondentes a valores para concentração de nitrogênio de 9,44 e $34,72 \mathrm{~g} \mathrm{~kg}^{-1}$ ), considerando as doses de nitrogênio de 0 e $600 \mathrm{~kg} \mathrm{ha}^{-1}$ ano $^{-1}$, respectivamente.

Alves (2000) obteve respostas lineares para a concentração de proteina bruta nas frações lâmina, colmo e planta inteira do capim-Tifton 85 , em função das doses de nitrogênio e da altura de corte das plantas. Os valores estimados para proteína bruta ponderada para a planta inteira com doses de 
nitrogênio de 0 e $133 \mathrm{~kg} \mathrm{ha}^{-1}$ variaram de 74 a 181, 155 a 160 e 36 a 144 para a planta colhida ao atingir as alturas de 30,40 e 50, cm respectivamente.

No presente experimento foi possível verificar, no primeiro corte, efeito significativo $(P<0,05)$ da época de aplicação de nitrogênio na concentração de nitrogênio no tecido da gramínea. A mais elevada concentração de nitrogênio na parte aérea das plantas foi obtida quando a adubação foi realizada aos sete dias após o corte e as médias observadas foram de 13,66 e $14,74 \mathrm{~g} \mathrm{~kg}^{-1}$ para as épocas de aplicação de nitrogênio após o corte e aos sete dias após o corte, respectivamente.

Por ocasião do segundo corte da forrageira a interação entre doses e épocas de aplicação de nitrogênio foi significativa $(P<0,05)$ em termos da concentração de nitrogênio na matéria seca da parte aérea. $O$ desdobramento dessa interação mostrou efeito significativo $(P<0,05)$ das doses de nitrogênio, em ambas as épocas de fornecimento de nitrogênio. Esse efeito das doses de nitrogênio foi representado por modelo quadrático de regressão (Figura 6). Observou-se também efeito significativo $(P<0,05)$ na concentração de nitrogênio da parte aérea para a época de aplicação, dentro das doses de nitrogênio de 160 e $240 \mathrm{mg} \mathrm{kg}^{-1}$ de solo. A concentração de nitrogênio no tecido das plantas adubadas sete dias após o corte foi superior àquelas das adubadas imediatamente após o corte, tendo sido observados os valores de 14,87 e $16,3 \mathrm{~g} \mathrm{~kg}^{-1}$ na dose de nitrogênio de $160 \mathrm{mg} \mathrm{kg}^{-1}$ de solo e $22,15 \mathrm{e}$ $23,48 \mathrm{~g} \mathrm{~kg}^{-1}$ na dose $240 \mathrm{mg} \mathrm{kg}^{-1}$ de solo, para as épocas de adubação imediatamente após o corte e de sete dias após o corte, respectivamente. 


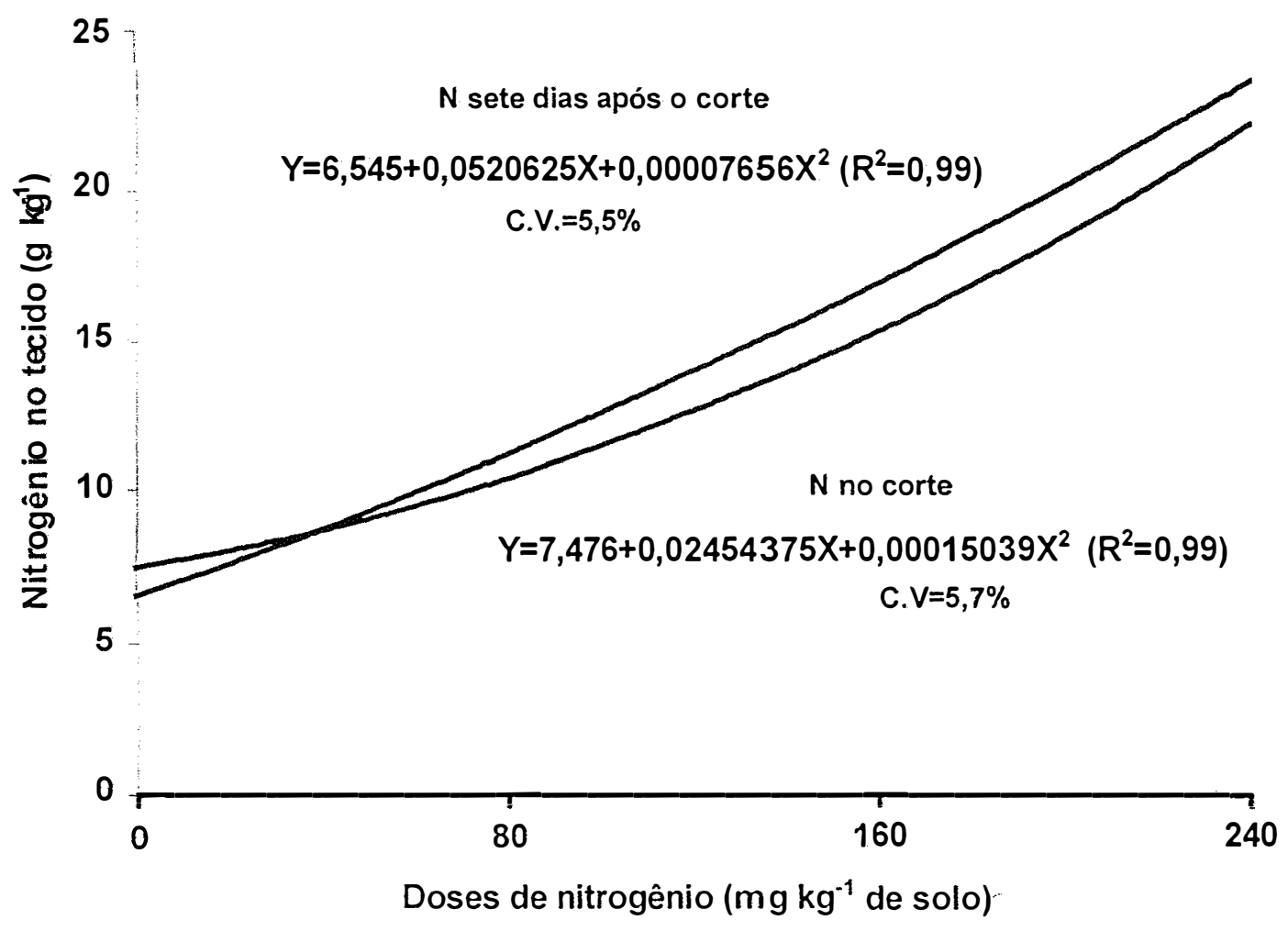

Figura 6 - Concentração de nitrogênio na matéria seca da parte aérea do segundo corte do capim-Tifton 85, em função das doses de nitrogênio aplicadas em duas épocas.

A época de aplicação de nitrogênio afetou o valor nutritivo da forragem no parâmetro concentração de nitrogênio no tecido, embora não se tenha verificado efeito significativo na produção de matéria seca da forrageira. A duração do período de crescimento das plantas de 39 e 41 dias pode ter sido suficiente para que o máximo potencial de crescimento das plantas fosse atingido, com as plantas compensando um possivel atraso inicial no crescimento quando a adubação foi realizada sete dias após o corte. Acompanhando a cinética de acúmulo da biomassa aérea após a desfolha em uma pastagem, observa-se numa etapa final de crescimento da forrageira que há um equilíbrio entre o surgimento e a morte das folhas, com a produção 
colhivel permanecendo quase constante (Nabinger, 1996). Neste experimento, a plantas adubadas nas duas épocas distintas podem ter atingido seu potencial de produção ao final do periodo experimental, contudo, se apresentando em fase de crescimento vegetativo diferenciada no momento do corte, com plantas consideradas mais jovens quando a adubação nitrogenada foi realizada sete dias após o corte.

A análise do crescimento da planta em relação a fração colmo+bainha contribuiu para esta hipótese. A análise de variância mostrou efeito significativo $(P<0,05)$ das épocas de aplicação de nitrogênio na produção de matéria seca do colmo+bainha, tanto no primeiro como no segundo cortes das plantas, enquanto o mesmo não ocorreu $(P>0,05)$ com a produção da lâmina foliar da graminea. Verificou-se mais elevada produção do colmo+bainha nas plantas adubadas imediatamente após o corte, consideradas mais velhas neste experimento, obtendo-se os valores de 15,95 e 14,83 g/vaso e de 21,42 e $20,05 \mathrm{~g} /$ vaso, para as épocas de aplicação de nitrogênio após o corte e sete dias após o corte, no primeiro e segundo crescimentos, respectivamente. Esta relação entre produção de hastes e de folhas com idade da planta está de acordo com o modelo de partição de matéria seca obtido por Overman \& Wilkson (1989) para os capins bermuda. Esses autores observaram que a produção das hastes nos capins bermuda apresenta uma dependência linear com o intervalo entre cortes, com aumentos na produção de matéria seca desta fração em função do número de semanas decorridos entre um corte e outro, enquanto a produção de matéria seca das folhas tem caráter independente do intervalo entre cortes. A produção das hastes foi incrementada numa velocidade maior com a aplicação de nitrogênio em relação ao observado para a produção de folhas.

É plenamente conhecido o fato da fração colmo+bainha das plantas possuir mais baixa concentração de nitrogênio (e de proteina bruta) que a lâmina foliar, como foi observado por Ferrari Jr. et al. (1993) para o Coastcross e a menor quantidade de colmo+bainha observadas para o capim-Tifton 85 , 
quando o nitrogênio foi aplicado sete dias após o corte, pode explicar a mais elevada concentração de nitrogênio na planta nessa época.

Existe uma relação negativa entre idade da planta e a concentração de nitrogênio no tecido vegetal. Gomide (1996), estudando cinco cultivares de Cynodon, relatou que a idade da planta foi o fator mais importante na queda da concentração de proteína das forrageiras, em todas as partes da planta, com o avanço da idade do seu desenvolvimento vegetativo. Para o capim-Tifton 85 a concentração de proteína bruta na planta inteira observada para as idades de 28 e 42 dias foi de 142 para $103 \mathrm{~g} \mathrm{~kg}^{-1}$ (correspondendo a concentração de nitrogênio de 22,72 e $16,48 \mathrm{~g} \mathrm{~kg}^{-1}$ ), respectivamente. Alvim et al. (1998) observaram uma diminuição significativa na concentração média anual de proteina bruta do capim-Tifton $85 \mathrm{com}$ a extensão no intervalo entre cortes, principalmente quando as mais elevadas doses de nitrogênio foram aplicadas na pastagem.

As doses de nitrogênio resultaram em efeito significativo $(P<0,05)$ na concentração de nitrogênio na matéria seca das raízes e esse efeito foi representado por modelo de regressão linear (Figura 7).

Martim (1997) observou que concentração de nitrogênio nas raizes do capim-Tifton 85 variou com a adubação nitrogenada, segundo um modelo quadrático. 


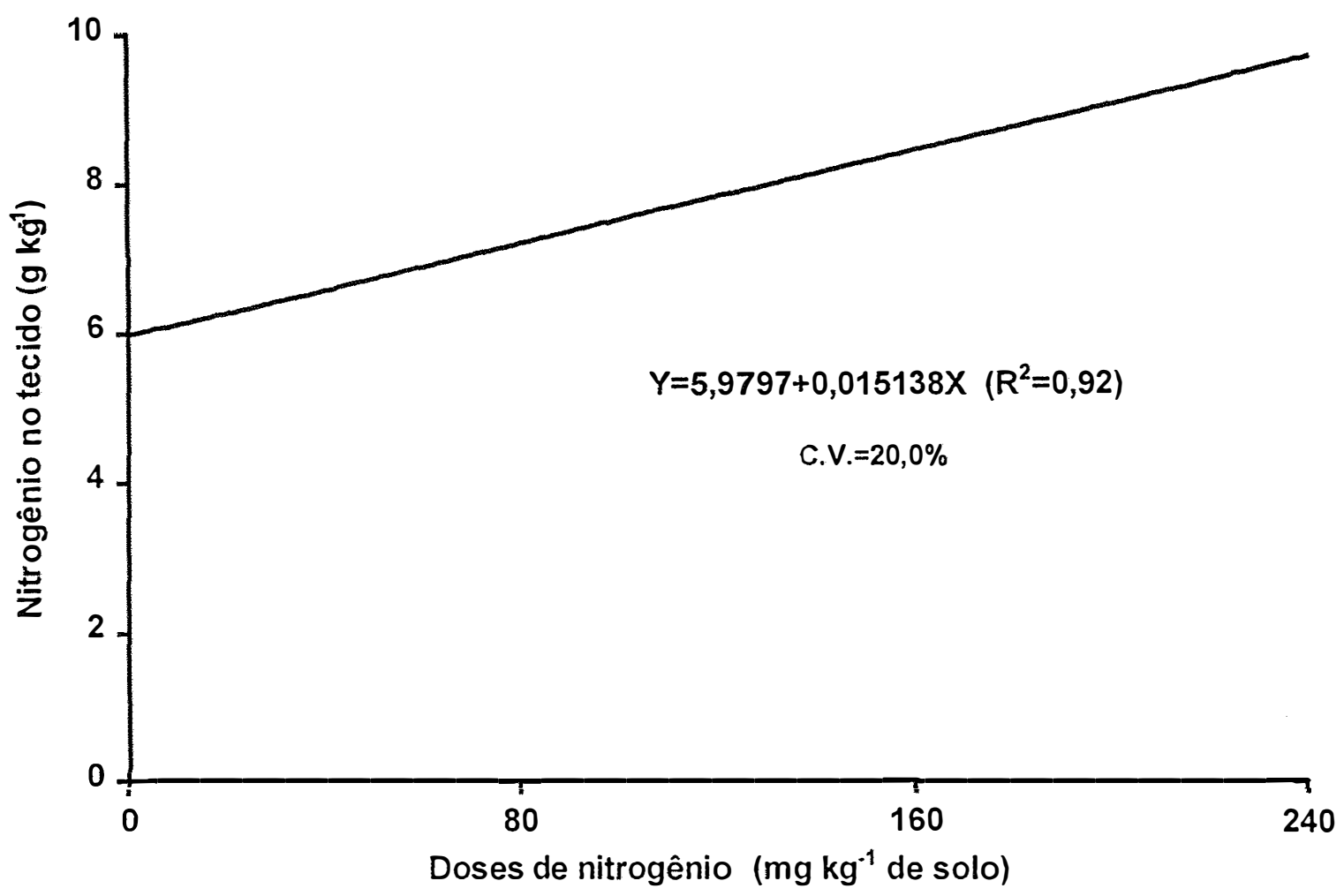

Figura 7 - Concentração de nitrogênio na matéria seca das raízes do capimTifton 85, em função das doses de nitrogênio. 


\subsubsection{Perfilhamento}

No primeiro crescimento do capim-Tifton 85 a análise de variância não mostrou efeito significativo $(P<0,05)$ das causas de variação relacionadas ao fornecimento de nitrogênio no número inicial de perfilhos e obteve-se a média de 45 perfilhos/vaso (Figura 8).

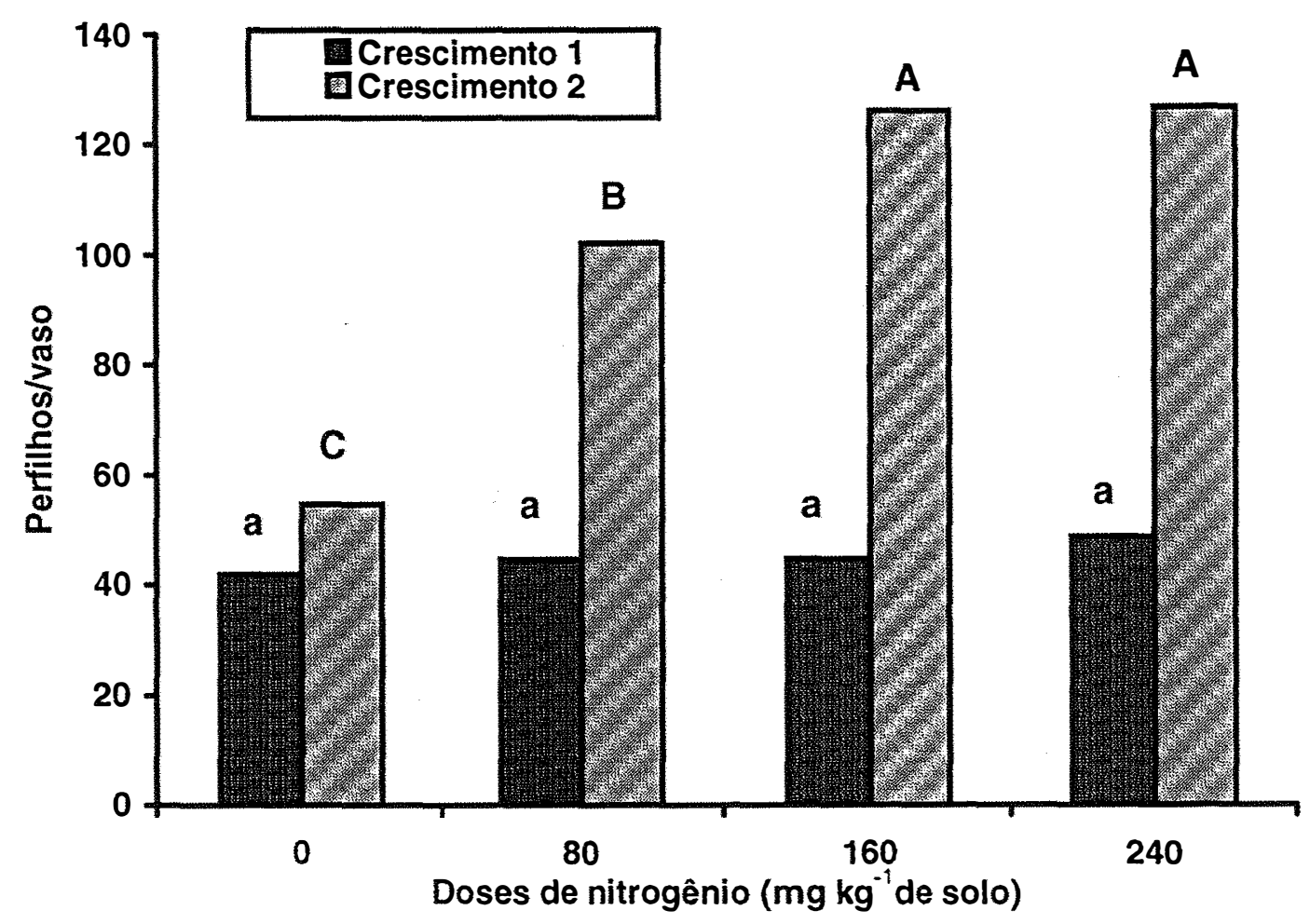

Figura 8 - Número inicial de perfilhos do capim-Tifton 85 , no primeiro e segundo crescimentos, em função das doses de nitrogênio. Letras diferentes indicam diferença significativa $(P<0,05)$ entre as médias, pelo teste de Tukey, dentro de cada período de crescimento da gramínea.

No segundo crescimento houve efeito significativo $(P<0,05)$ da dose de nitrogênio no número inicial de perfilhos de 0 até a dose de nitrogênio de 160 
$\mathrm{mg} \mathrm{kg}^{-1}$ de solo (Figura 8). Este efeito é provavelmente um reflexo da ação do nitrogênio no primeiro crescimento das plantas. As doses de nitrogênio de 160 e $240 \mathrm{mg} \mathrm{kg}^{-1}$ de solo propiciaram números iniciais iguais de perfilhos no capim.

Tanto no primeiro quanto no segundo crescimento da forrageira houve efeito significativo $(P<0,05)$ das doses de nitrogênio no aumento do número parcial e do total de perfilhos do capim (Figuras 9 e 10).

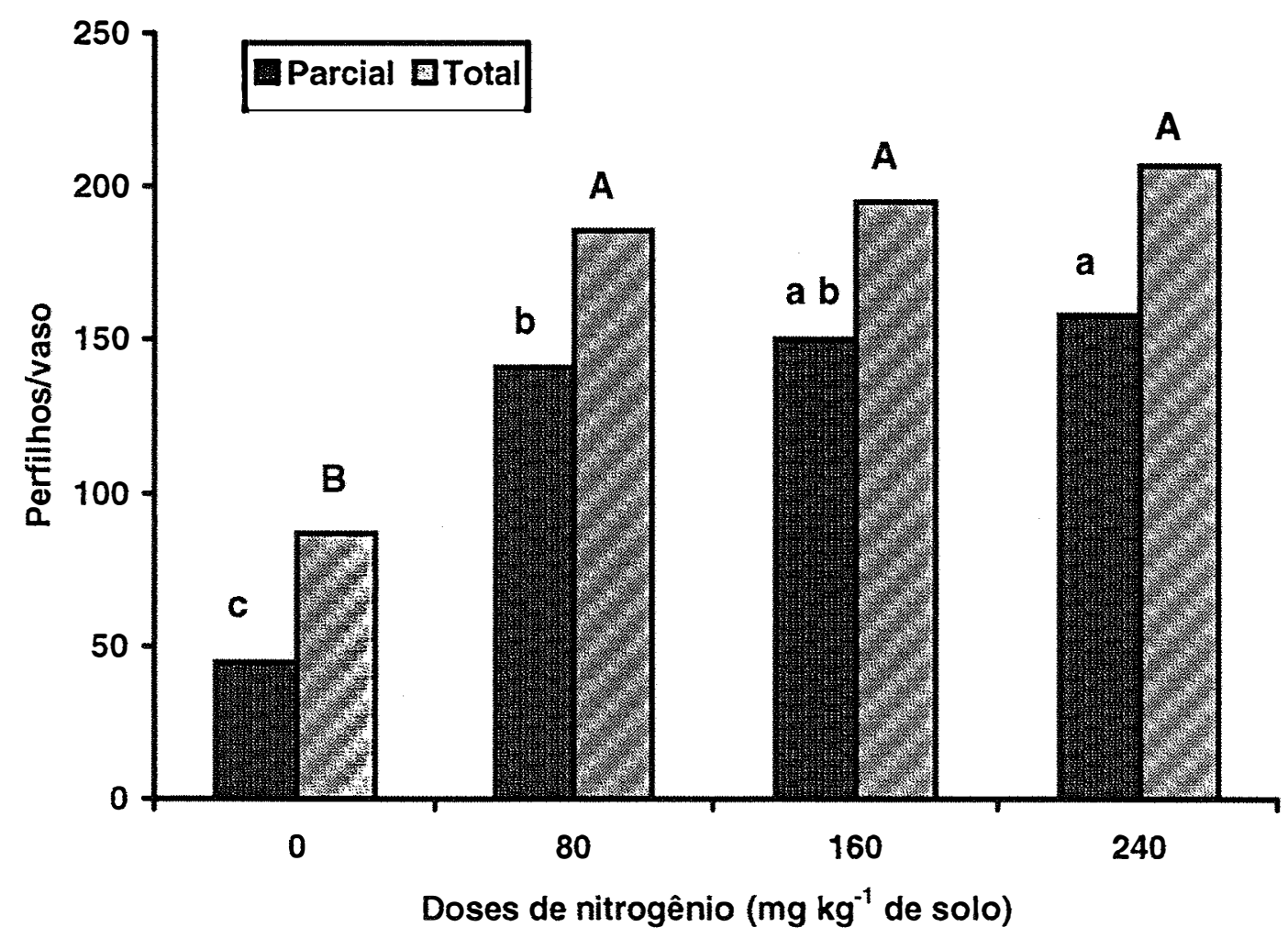

Figura 9 - Número de perfilhos parcial e total no primeiro crescimento do capimTifton 85 , em função das doses de nitrogênio. 


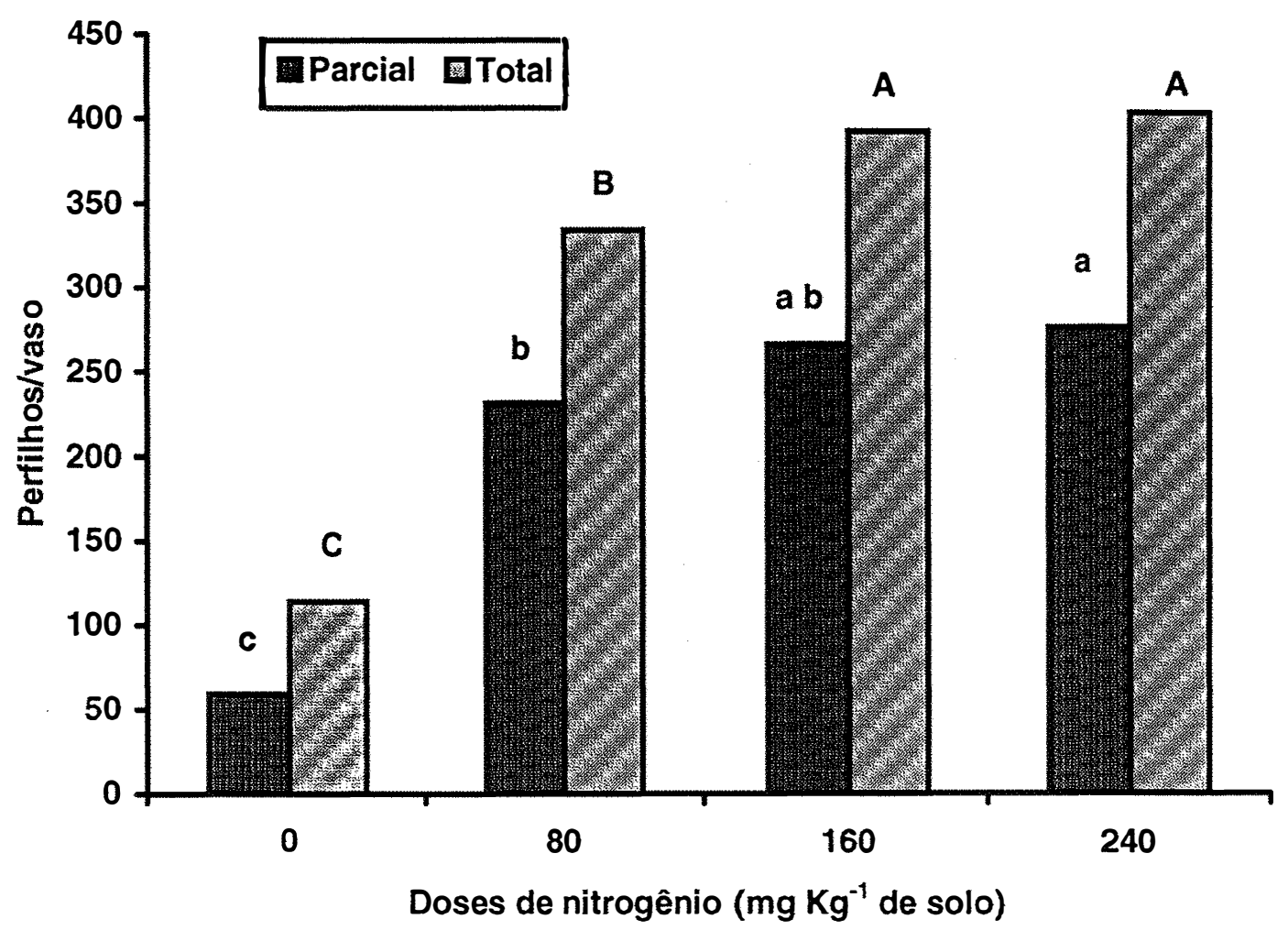

Figura 10 - Número de perfilhos parcial e total no segundo crescimento do capim-Tifton 85 , em função das doses de nitrogênio.

No primeiro crescimento o número parcial de perfilhos foi mais sensível ao efeito do suprimento de nitrogênio do que o número total de perfilhos, tendo sido observadas diferenças significativas entre a não aplicação desse nutriente e as doses de 80; 160 e $240 \mathrm{mg} \mathrm{kg}^{-1}$ de solo para o número parcial de perfilhos, com diferença entre as doses de 80 e $240 \mathrm{mg} \mathrm{kg}^{-1}$ de solo, e entre o não fornecimento de nitrogênio e as demais doses para o número total de perfilhos. No segundo crescimento foram observadas diferenças significativas entre a não aplicação do nitrogênio e as doses de 80; 160 e 240 $\mathrm{mg} \mathrm{kg}^{-1}$ de solo para o número parcial e total de perfilhos, com a dose de 80 diferindo de $240 \mathrm{mg} \mathrm{kg}^{-1}$ de solo para o número parcial perfilhos e com a dose 80 diferindo de 160 e $240 \mathrm{mg} \mathrm{kg}^{-1}$ de solo para o número total de 
perfilhos. Simon \& Lemaire (1987) reportaram para o Italian ryegrass que adubação com nitrogênio resultou em aumento do número de perfilhos por planta somente em uma fase inicial do crescimento, e à medida em que o índice de área foliar aumentou esse efeito praticamente desapareceu.

Efeito da aplicação de nitrogênio para o perfilhamento do capim-Tifton 85 foi relatado por Paulino et al. (1997). Descreveram um efeito linear das doses de nitrogênio de 0,50 e $150 \mathrm{~kg} \mathrm{ha}^{-1}$ no aumento do número de perfilhos por vaso e apresentaram o máximo valor de 54,3 perfilhos/vaso. Esse máximo de perfilhos é, em número absoluto, bem inferior aos obtidos no presente experimento.

Trabalhando com azevém, Wilman \& Pearse (1984) empregaram doses de nitrogênio de 0, 66 e $132 \mathrm{~kg} \mathrm{ha}^{-1}$ e observaram 844, 988 e 1076 como o número de perfilhos para $0,1 \mathrm{~m}^{2}$ e 0,$05 ; 0,27$ e 0,38 como a taxa semanal de aparecimento de perfilhos, respectivamente. Herling et al. (1991) obtiveram aumentos no perfilhamento de capim-setária da não aplicação para as doses de nitrogênio de 80 e $160 \mathrm{~kg} \mathrm{ha}^{-1}$, com valores de 11,49; 14,74 e 15,06 perfilhos/vaso, respectivamente.

Harris et al. (1996) relataram um aumento na densidade dos perfilhos de azévem de 4072, 6295, 6673 perfilhos $\mathrm{m}^{-2}$ e número de perfilhos por planta de 3,$37 ; 4,10$, e 4,26 quando as doses de nitrogênio foram de 0; 200 e $400 \mathrm{~kg} \mathrm{ha}{ }^{-1}$, respectivamente. Aumento na densidade total de perfilhos (perfilhos $\mathrm{m}^{-2}$ ) de azevém até a dose de $480 \mathrm{~kg} \mathrm{ha}^{-1} \mathrm{ano}^{-1}$ foi obtido por Mackenzie (1998) quando foram utilizadas as doses de nitrogênio de 120, 240 , 360,600 e $720 \mathrm{~kg} \mathrm{ha}^{-1} \mathrm{ano}^{-1}$.

Mattos et al. (1997), ao testarem doses de nitrogênio (50, $100 \mathrm{e}$ $150 \mathrm{mg} \mathrm{dm}^{-3}$ ) em algumas gramíneas forrageiras, constataram que essa adubação proporcionou aumento número de perfilhos por perfilho principal e que essa resposta foi quadrática nas plantas de milheto (Pennisetum americanum) e linear para o capim- sudão (Sorghum sudanense ). 
Para o capim-Tifton 85 os números total e parcial de perfilhos correlacionaram-se siginificativamente $(P<0,05)$ com o número inicial de perfilhos. Os valores do coeficiente de correlação foram de 0,40 e 0,50 para o primeiro crescimento e 0,89 e 0,94 para segundo crescimento nas relações do número inicial de perfilhos com o perfilhamento parcial e total, respectivamente. Os valores mais elevados de correlação obtidos no segundo crescimento significam que o efeito das doses de nitrogênio no perfilhamento esteviveram associados a uma maior densidade de perfilhos pré-existentes.

No segundo crescimento os números parcial e total de perfilhos foram maiores do que os do primeiro periodo, refletindo o fato de já ter ocorrido o estabelecimento das plantas. Essa observação com relação aos perfilhos é compativel com os máximos de produção de matéria seca da parte aérea para o primeiro e segundo cortes. Tanto no primeiro como no segundo corte observou-se alta correlação entre produção de matéria seca da parte aérea e número total de perfilhos, com os valores de coeficiente de correlação de 0,92 e 0,94 para o primeiro e segundo cortes, respectivamente.

As doses de doses de nitrogênio que possibilitaram os máximos valores para produção matéria seca da parte aérea foram mais elevadas que aquelas promotoras de maior perfilhamento das plantas. Os valores das doses de nitrogênio obtidas para a máxima produção de matéria seca da parte aérea foram 217 e $205 \mathrm{mg} \mathrm{kg}^{-1}$ de solo, enquanto que o maior perfilhamento (total e parcial) ocorreu na dose de nitrogênio de $160 \mathrm{mg} \mathrm{kg}^{-1}$ de solo. Segundo Mathew et al. (1999) a produção de novos perfilhos cessa antes que um equilíbrio na produção de área foliar seja atingido. À medida que a área foliar do dossel se acumula a proporção de luz correspondente ao comprimento de onda vermelho para o vermelho distante, que promove a liberação das gemas e a produção de novos perfilhos, diminui. Com o incremento no índice de área foliar, o perfilhamento diminui e a taxa de elongação das folhas pode se elevar, significando uma adaptação das plantas à competição por luz (Simon \& Lemaire, 1987). 
Quando as plantas atingem seu máximo potencial em número de perfilhos a contribuição desses perfilhos para na produção de matéria seca da parte aérea passa a ser em termos de peso de perfilhos. Segundo Corsi \& Nascimento Jr. (1986) alterações no peso do perfilho ocorrem através da distribuição dos carboidratos produzidos pela fotossíntese entre a parte aérea e o sistema radicular e através dos ritmos de alongação das folhas e expansão da área foliar. A plasticidade fenotípica explica uma relação inversa existente entre densidade de perfilhos e peso de perfilhos (Chapman \& Lemaire, 1993) e foi demonstrado por Sbrissia et al., (1999) para o o capim-Tifton 85 e Boggiano et al. (1999) para Paspalum notatum .

$O$ peso de perfilhos individuais foi significativamente $(P<0,05)$ influenciado pelas doses de nitrogênio. Esse efeito do nitrogênio foi representado por modelo quadrático de regressão tanto no primeiro quanto no segundo corte (Figura 11). No primeiro corte foi observado maior peso dos perfilhos individuais, devido provavelmente a um menor número total de perfilhos em cada unidade experimental, enquanto no segundo corte um maior perfilhamento determinou menor peso de perfilhos individuais. Pinto et al. (1994a) constataram uma resposta negativa no peso de perfilhos de capimsetária quando a mais alta dose de nitrogênio (entre as doses de $15 \mathrm{e}$ $90 \mathrm{mg} \mathrm{kg}^{-1}$ de solo) foi utilizada com as plantas com 42 dias de crescimento. Segundo os autores um maior número de perfilhos em crescimento e desenvolvimento competem entre si pelos assimilados produzidos pela planta, resultando num menor peso individual do perfilho. 


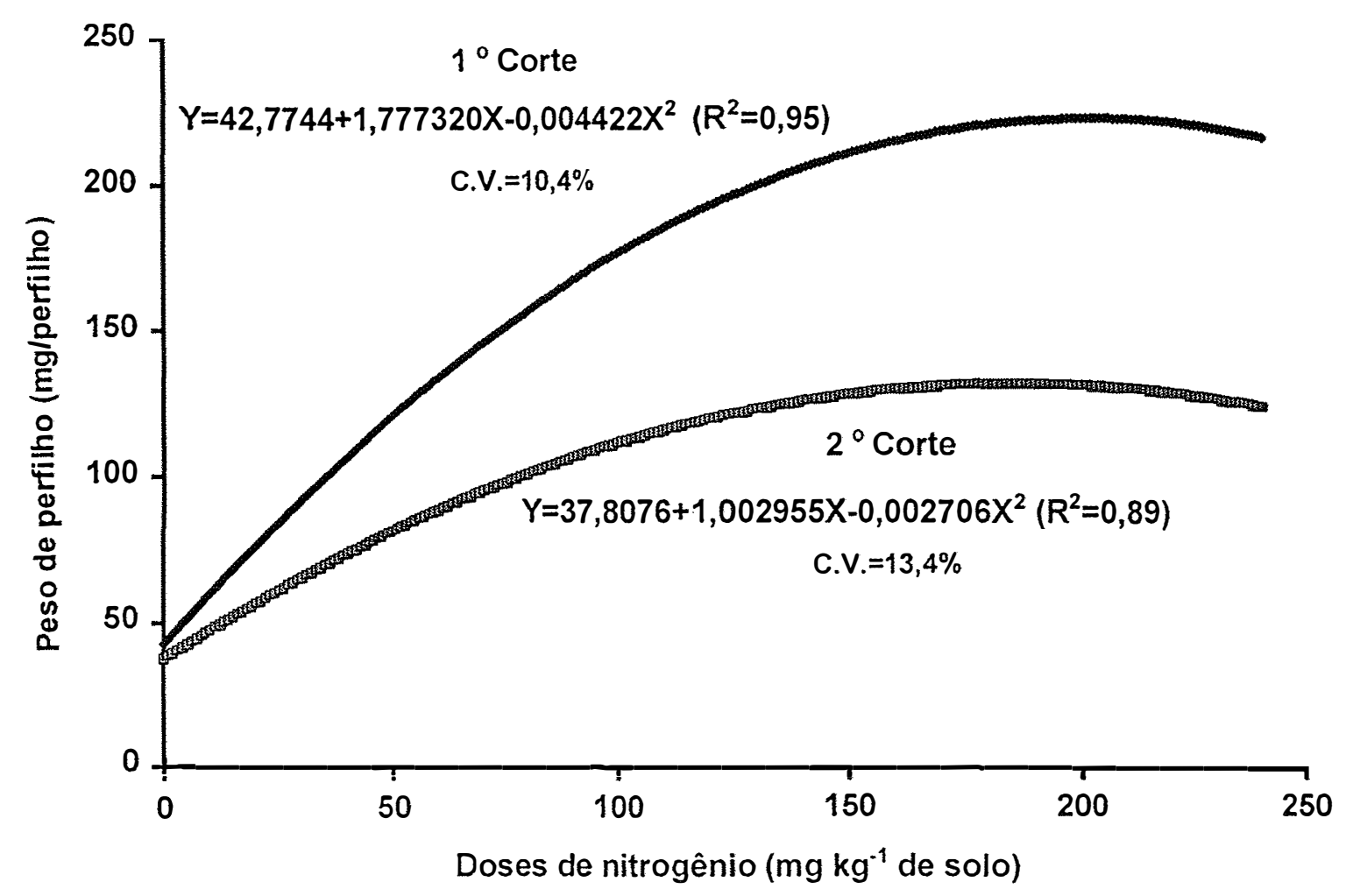

Figura 11- Peso dos perfilhos no primeiro e segundo cortes do capim-Tifton 85 , em função das doses de nitrogênio.

Os máximos valores estimados de peso de perfilhos individuais de 217 e $128 \mathrm{mg} /$ perfilho foram verificados nas doses de nitrogênio de 200 e 185 $\mathrm{mg} \mathrm{kg}^{-1}$ de solo, para o primeiro e o segundo corte, respectivamente. Essas doses foram superiores às observadas para proporcionar a máxima densidade de perfilhos e compatíveis com os constatados para proporcionar a máxima produção de matéria seca da parte aérea.

Sbrissia et al. (1999), estudando o perfilhamento do capim-Tifton 85, observaram que à medida em que o pasto foi mantido a alturas maiores (variando e 5 a $20 \mathrm{~cm}$ ) houve uma diminuição no número de perfilhos por unidade de área e um aumento no peso dos perfilhos individuais. Os valores para o peso de perfilhos foram de 22,8; 40,8; 84,9 e $124,0 \mathrm{mg} /$ perfilho nas 
alturas 5, 10, 15 e $20 \mathrm{~cm}$, respectivamente. O máximo valor relatado por esses autores teve a mesma magnitude que o obtido no segundo corte do presente experimento, mas foi inferior àquele do primeiro corte.

Wilman \& Pearse (1984) observaram um efeito significativo da aplicação de nitrogênio para o peso de perfilhos de azevém quando submetido a doses de 0; 66 e $132 \mathrm{~kg} \mathrm{ha}^{-1}$. Os valores observados foram de 0,8; 4,3 e 7,9 $\mathrm{mg} /$ perfilho e 6,$5 ; 12,1$ e $16,7 \mathrm{~cm}$ para comprimento de lâmina foliar, respectivamente.

\subsubsection{Crescimento das folhas}

O comprimento e a área final da lâmina foliar do capim-Tifton 85 foram significativamente $(P<0,05)$ influenciadas pelas doses de nitrogênio e pela interação entre doses e épocas de aplicação de nitrogênio. O comprimento da lâmina foliar na primeira e segunda avaliações, e a área da lâmina foliar na primeira avaliação foram significativamente $(P<0,05)$ alterados pelas doses de nitrogênio. Para comprimento da lâmina foliar na terceira e quarta avaliações e para área da lâmina foliar na segunda, terceira e quarta avaliações foi observado efeito significativo $(P<0,05)$ da interação entre doses e épocas de aplicação de nitrogênio. Aumentos na taxa de expansão foliar em função do suprimento de nitrogênio foram também observados por Pearse \& Wilman (1984) com o azevém e por Gastal et al. (1992) com a festuca.

Maan et al. (1989) relataram aumento expressivo na área da lâmina foliar de cevada quando as doses de nitrogênio variaram de 40 a $320 \mathrm{mg} \mathrm{L}^{-1}$. Andrews et al. (1991) destacaram aumento no comprimento final da folha em cereais quando as doses de nitrato variaram de 0,1 a 5,0 $\mathrm{mol} \mathrm{m}^{-3}$.

No primeiro crescimento o nitrogênio proporcionou variação significativa $(P<0,05)$ no comprimento da lâmina foliar do capim-Tifton 85. Essa variação se traduziu em modelos quadráticos de regressão (Figura 12) e os máximos valores estimados para essa variável foram de 193 e 158 mm, obtidos 
com aplicação de nitrogênio de 162 e $187 \mathrm{mg} \mathrm{kg}^{-1}$ de solo, na primeira e segunda avaliações, respectivamente.

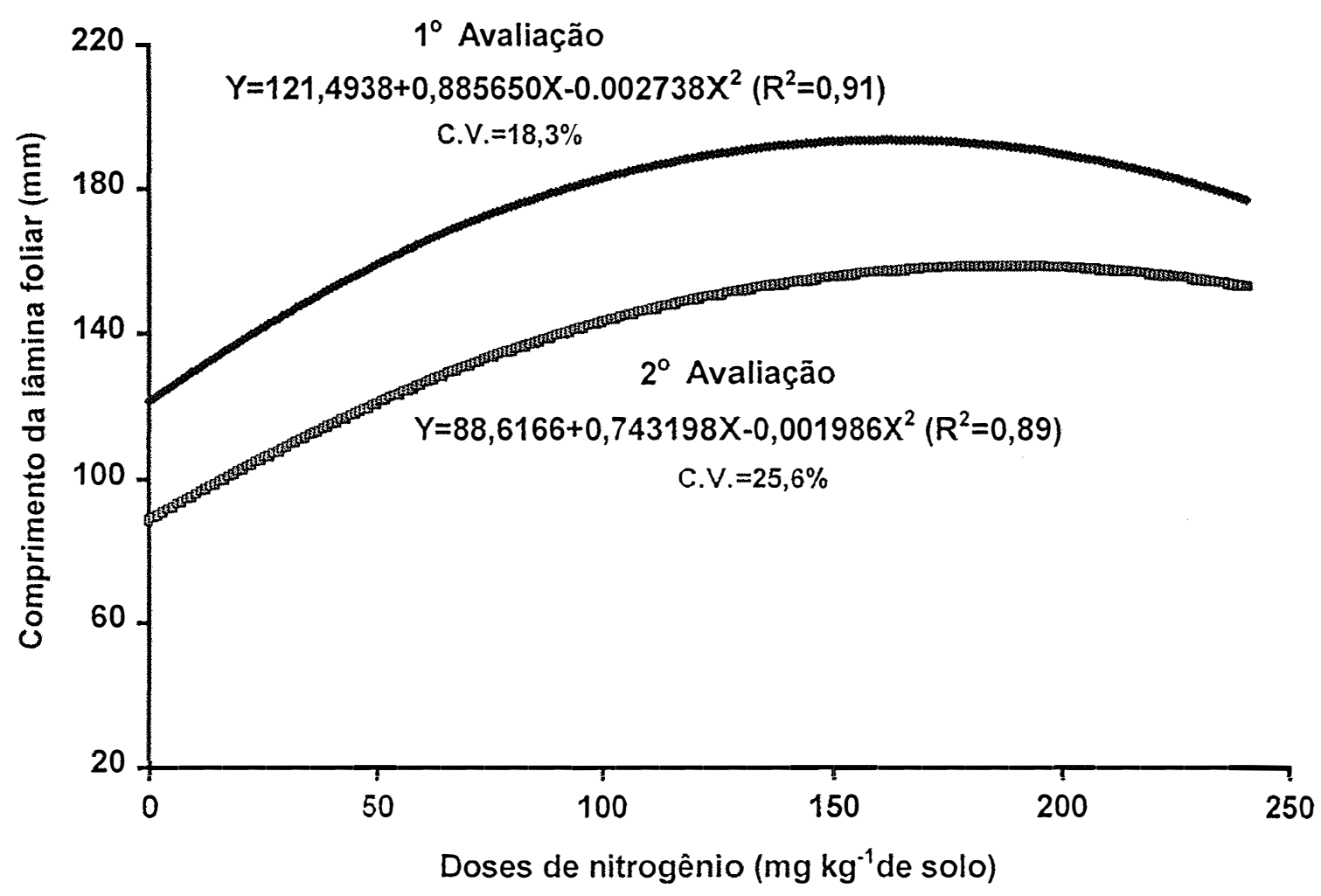

Figura 12 - Comprimento da lâmina foliar nas duas avaliações do primeiro crescimento do capim-Tifton 85 , em função das doses de nitrogênio.

Para a área da lâmina foliar na primeira avaliação do capim-Tifton 85 também se verificou significância $(P<0,05)$ às doses de nitrogênio. Os resultados se ajustaram a modelo quadrático, com o máximo valor estimado de $845 \mathrm{~mm}^{2}$ obtido na dose de nitrogênio de $165 \mathrm{mg} \mathrm{kg}^{-1}$ de solo (Figura 13). 


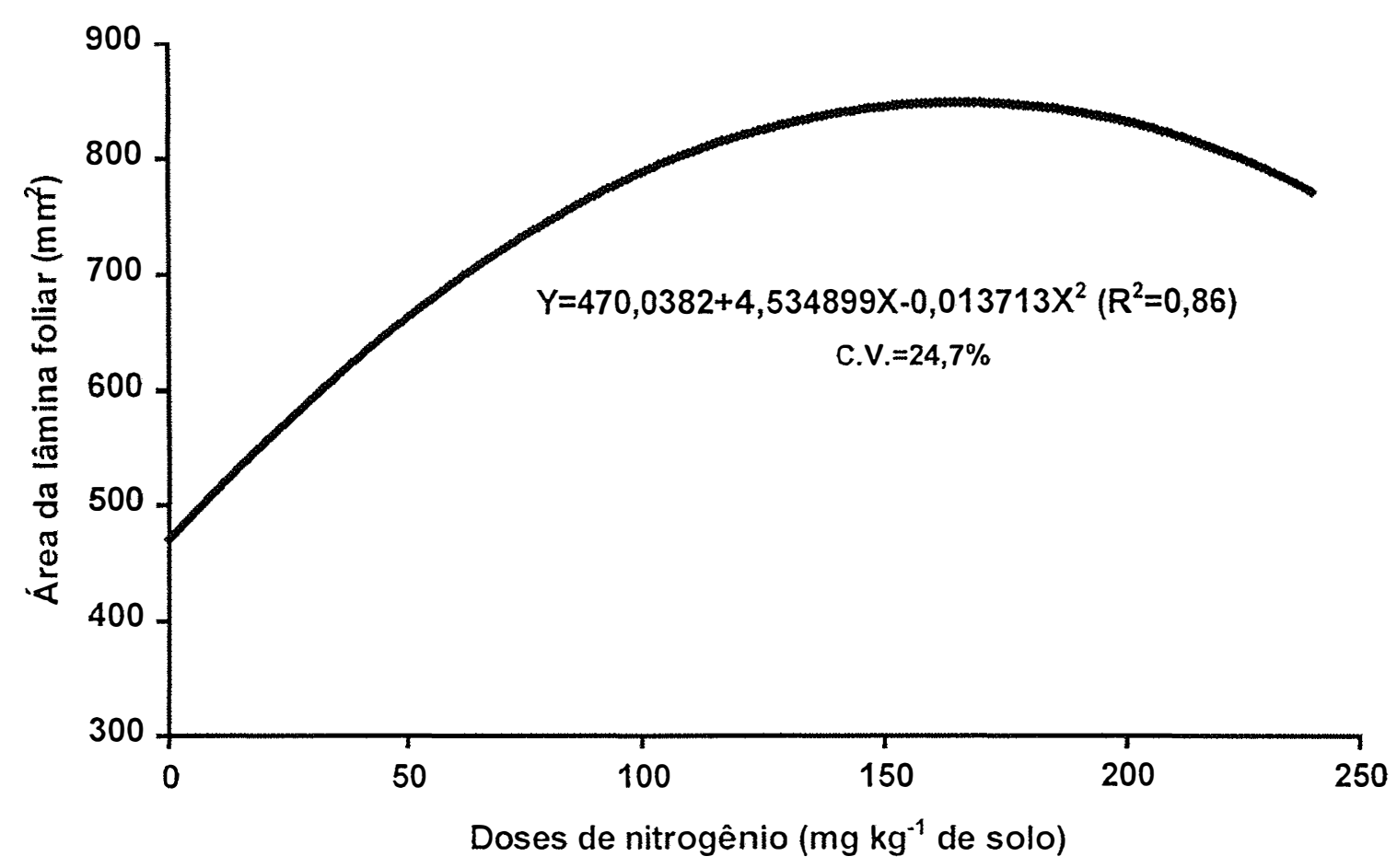

Figura 13 - Área da lâmina foliar na primeira avaliação do capim-Tifton 85, em função das doses de nitrogênio.

Na segunda avaliação houve efeito significativo $(P<0,05)$ da interação entre doses e épocas de aplicação de nitrogênio após o corte na área da lâmina foliar do capim-Tifton 85. O desdobramento dessa interação mostrou efeito significativo $(P<0,05)$ das doses de nitrogênio em ambas as épocas de fornecimento após o corte. Esse efeito foi representado por modelo linear de regressão quando o nitrogênio foi aplicado no momento do corte, e por um modelo quadrático quando o nitrogênio foi aplicado sete dias após o corte, obteve-se valor máximo de $765 \mathrm{~mm}^{2}$ na dose de nitrogênio de $162 \mathrm{mg} \mathrm{kg}^{-1} \mathrm{de}$ solo (Figura 14). Observou-se também efeito significativo $(P<0,05)$ das épocas de aplicação de nitrogênio na dose de $80 \mathrm{mg} \mathrm{kg}^{-1}$ de solo, obtendo-se os 
valores de 585 e $793 \mathrm{~mm}^{2}$ quando essa adubação foi realizada no momento do corte e sete dias após o corte, respectivamente.

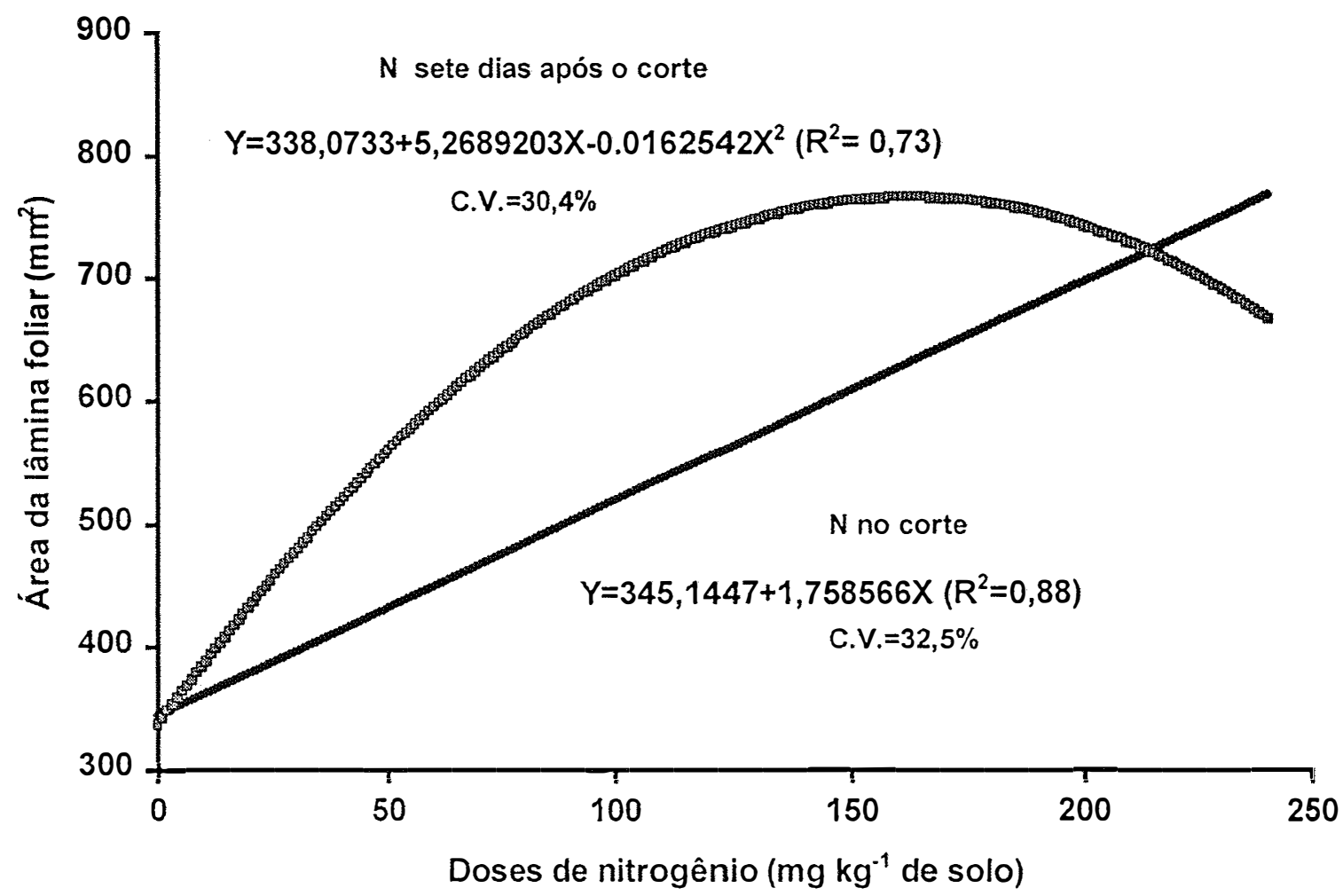

Figura 14 - Área da lâmina foliar na segunda avaliação do capim Tifton 85, em função das doses de nitrogênio aplicadas em duas épocas.

No segundo crescimento houve efeito significativo $(P<0,05)$ da interação entre as doses e épocas de aplicação de nitrogênio após o corte, para o comprimento e a área da lâmina foliar do capim-Tifton 85.

Considerando o comprimento da lâmina foliar, o desdobramento dessa interação mostrou efeito significativo $(P<0,05)$ das doses nas duas épocas de fornecimento de nitrogênio. O efeito das doses foi representado por modelo quadrático de regressão, em ambas as épocas de aplicação de nitrogênio, para a terceira e quarta avaliações. 
$\mathrm{Na}$ terceira avaliação (Figura 15) os valores máximos valores estimados para comprimento da lâmina foliar foram de 128 e $121 \mathrm{~mm}$ e foram obtidos nas doses de nitrogênio de 160 e $215 \mathrm{mg} \mathrm{kg}^{-1}$ de solo, quando o nitrogênio foi aplicado no momento do corte e sete dias após, respectivamente.

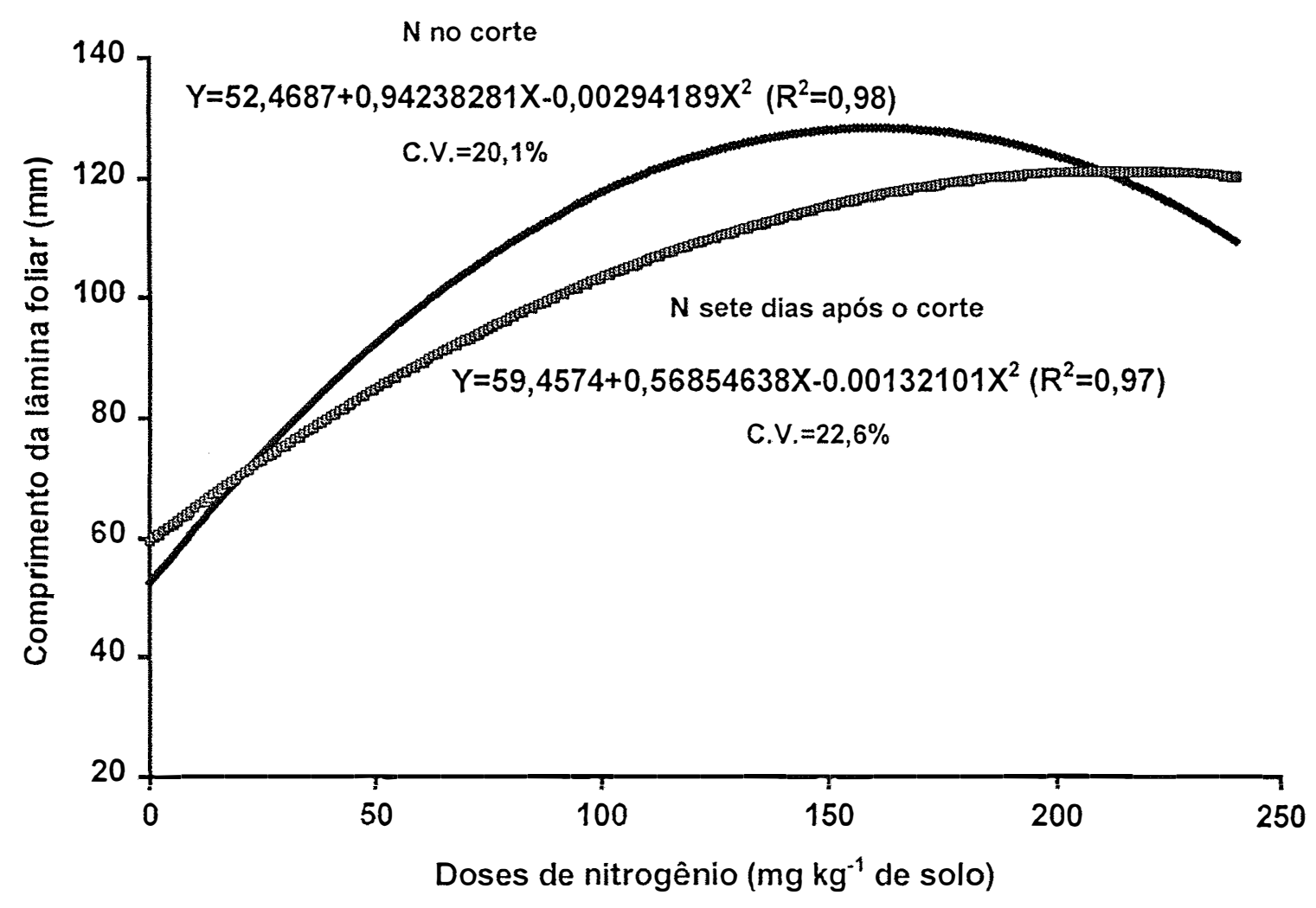

Figura 15 - Comprimento da lâmina foliar na terceira avaliação do capim-Tifton 85, em função das doses de nitrogênio aplicadas em duas épocas.

$\mathrm{Na}$ quarta avaliação foram observados os valores máximos de $143 \mathrm{e}$ $142 \mathrm{~mm}$ para comprimento da lâmina foliar e foram alcançados nas doses nitrogênio de 163 e $197 \mathrm{mg} \mathrm{kg}^{-1}$ de solo, considerando a aplicação de nitrogênio no momento do corte e sete dias após, respectivamente (Figura 16). 


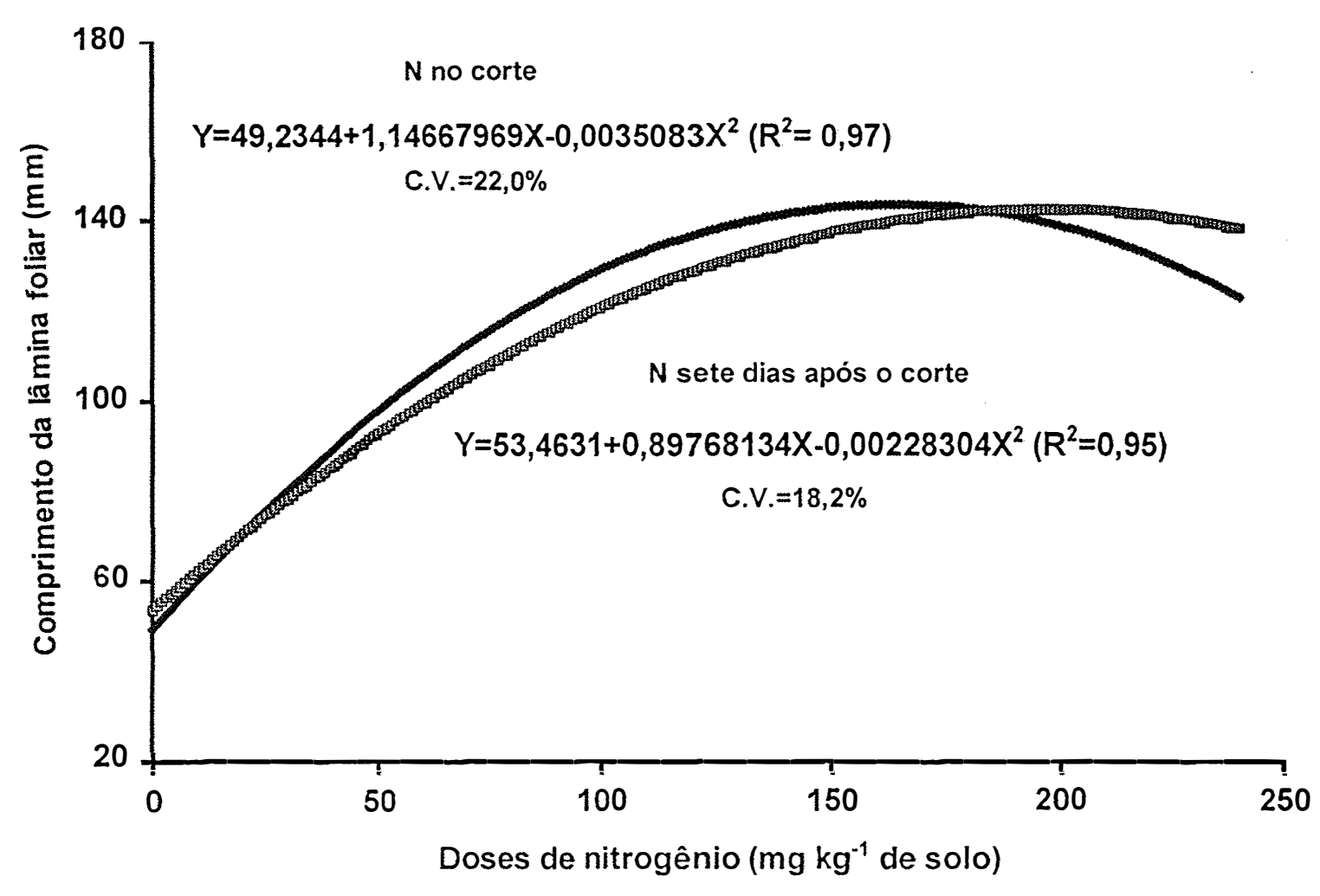

Figura 16 - Comprimento da lâmina foliar na quarta avaliação do capim-Tifton 85, em função das doses de nitrogênio aplicadas em duas épocas.

Houve efeito significativo $(P<0,05)$ das épocas de aplicação de nitrogênio no comprimento foliar na dose de nitrogênio de $160 \mathrm{mg} \mathrm{kg}^{-1}$ de solo, na terceira e quarta avaliações, quando foram observados os valores de $132 \mathrm{e}$ 108 mm e de 148 e 129 mm, considerando a aplicação de nitrogênio no momento do corte e sete dias após, respectivamente.

Para a área da lâmina foliar o desdobramento da interação entre doses e épocas de aplicação de nitrogênio também mostrou efeito significativo $(P<0,05)$ de doses nas duas épocas de fornecimento de nitrogênio. O modelo de regressão quadrática representou esses efeitos na terceira e quarta avaliações. 
Na terceira avaliação (Figura 17) os valores máximos estimados de área da lâmina foliar de 594 e $573 \mathrm{~mm}^{2}$ foram obtidos nas doses de nitrogênio de 166 e $226 \mathrm{mg} \mathrm{kg}^{-1}$ de solo, quando o nitrogênio foi aplicado no momento do corte e sete dias após, respectivamente.

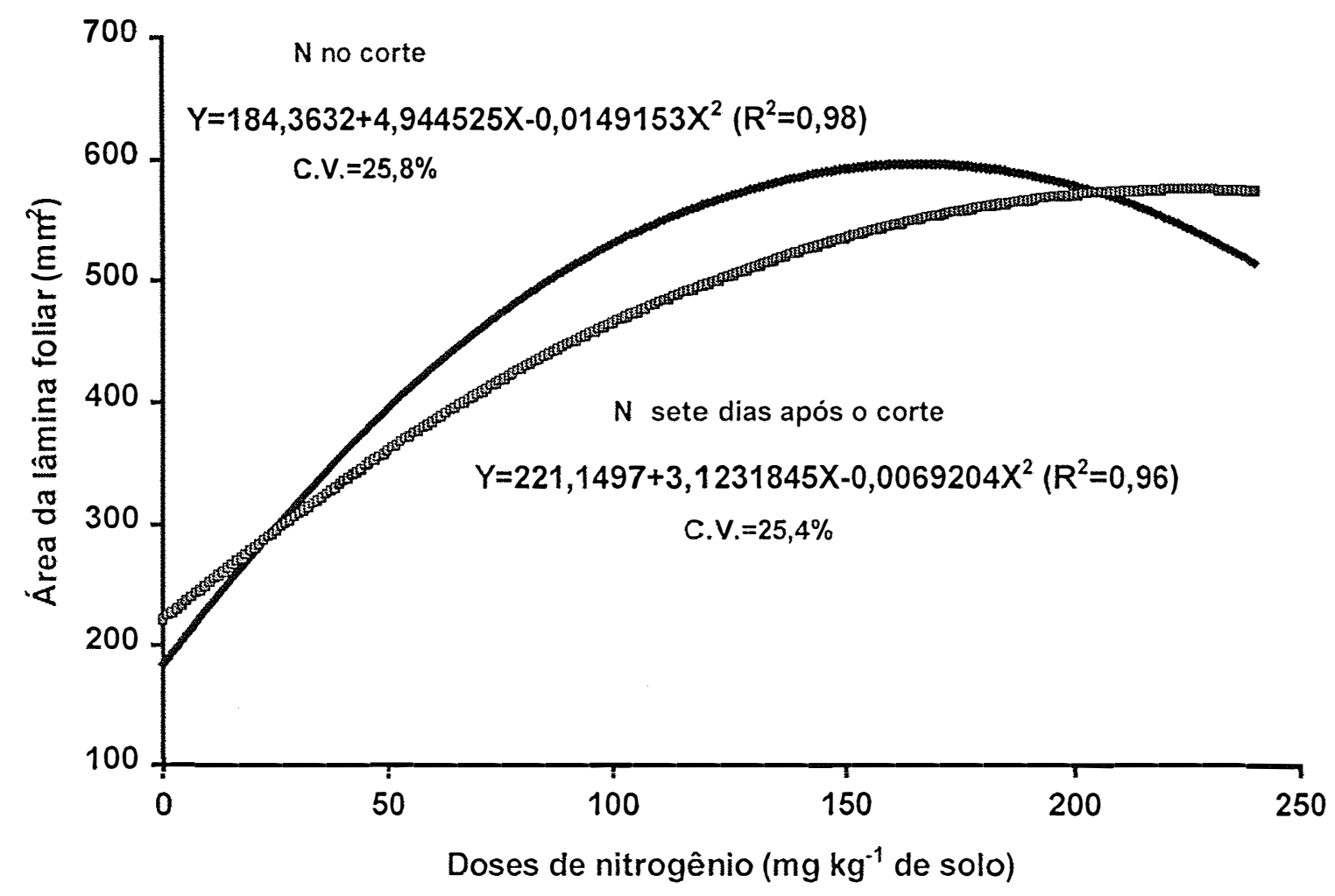

Figura 17 - Área da lâmina foliar na terceira avaliação do capim-Tifton 85, em função das doses de nitrogênio aplicadas em duas épocas.

Na quarta avaliação os valores máximos estimados de área da lâmina foliar foram de 614 e $645 \mathrm{~mm}^{2}$ e foram encontrados nas doses de nitrogênio de 173 e $194 \mathrm{mg} \mathrm{kg}^{-1}$ de solo, quando o nitrogênio foi aplicado no momento do corte e sete dias após o corte, respectivamente (Figura 18). 


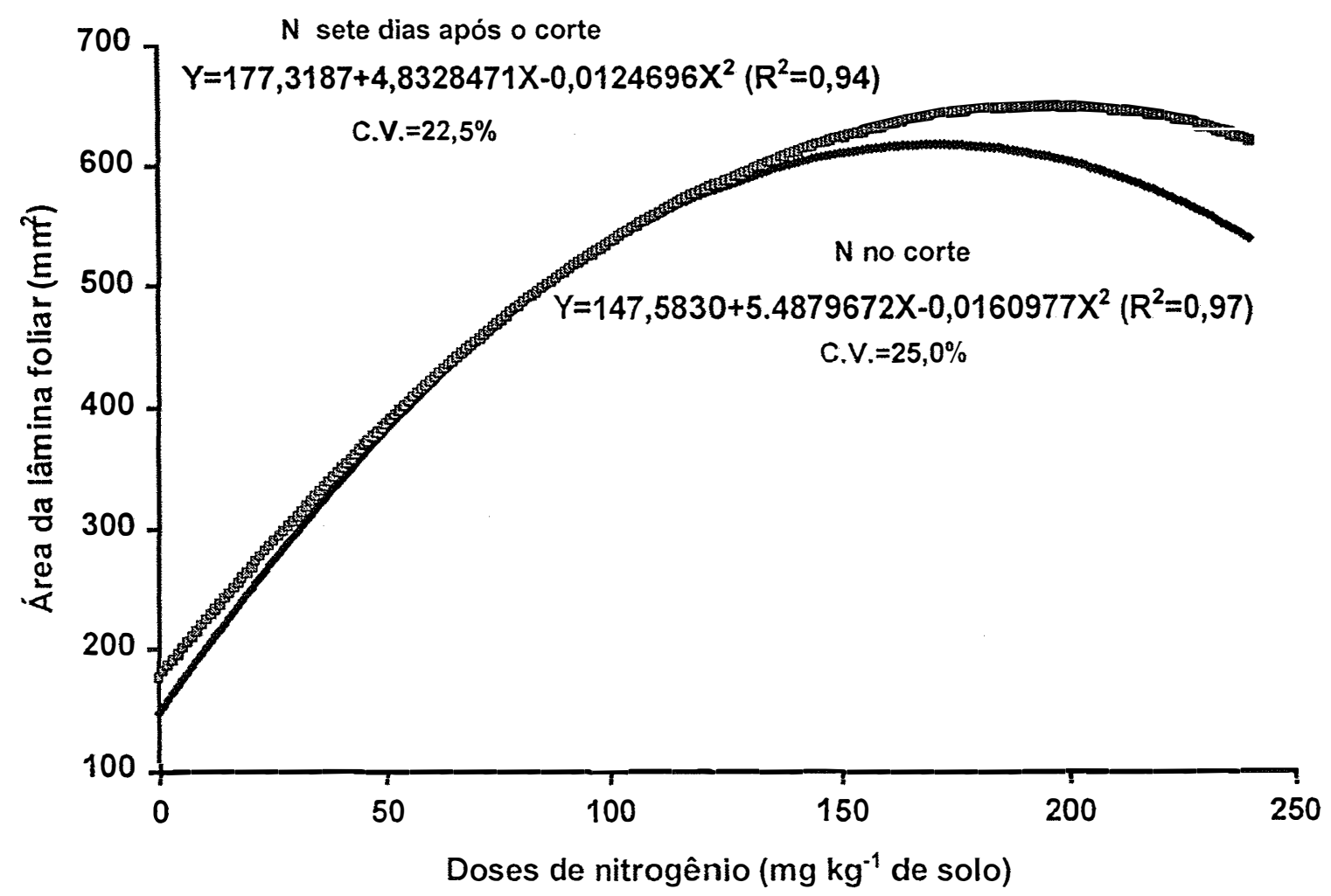

Figura 18 - Área da lâmina foliar na quarta avaliação do capim-Tifton 85 , em função das doses de nitrogênio aplicadas em duas épocas.

$\mathrm{Na}$ terceira e quarta avaliações foi verificado efeito significativo $(P<0,05)$ das épocas de fornecimento nitrogênio, em determinadas doses de nitrogênio, na área da lâmina foliar. $\mathrm{Na}$ terceira avaliação esse efeito foi observado na dose de nitrogênio de $160 \mathrm{mg} \mathrm{kg}^{-1}$ de solo, com valores de $607 \mathrm{e}$ $493 \mathrm{~mm}^{2}$ de área foliar obtidos quando o nitrogênio foi aplicado no momento do corte e sete dias após, respectivamente. Na quarta avaliação o efeito da época foi conseguido nas doses de 80 e $240 \mathrm{mg} \mathrm{kg}^{-1}$, alcançando-se os valores de 449 e $537 \mathrm{~mm}^{2}$ e de 526 e $638 \mathrm{~mm}^{2}$ considerando a aplicação de nitrogênio no momento do corte e sete dias após, para as doses de nitrogênio de 80 e 240 $\mathrm{mg} \mathrm{kg}^{-1}$ de solo, respectivamente. 
Analisando-se os efeitos das doses e épocas de aplicação do nitrogênio no segundo periodo de crescimento, observou-se que os valores máximos estimados para comprimento e área foliares foram atingidos nas doses de nitrogênio entre 160 e $170 \mathrm{mg} \mathrm{kg}^{-1}$ de solo quando o nitrogênio foi aplicado no momento do corte e em doses entre 200 a $220 \mathrm{mg} \mathrm{kg}^{-1}$ de solo, quando o nitrogênio foi aplicado sete dias após o corte. Observa-se portanto, quando a aplicação de nitrogênio foi realizada sete dias após o corte, que a expressão do potencial máximo de crescimento das folhas ocorreu em doses mais elevadas no fornecimento de nitrogênio. Esta resposta pode significar uma maior exigência em termos de nitrogênio quando o fornecimento foi realizado aos sete dias, uma vez que não foi observado efeito significativo da época de corte na produção de matéria seca das folhas.

De maneira geral, observou-se que os máximos valores estimados tanto para comprimento como para área da lâmina foliar foram inferiores no segundo periodo de crescimento, em relação ao primeiro periodo. Tendo-se em consideração que esses valores ocorreram em fornecimento similar de nitrogênio no solo nos dois periodos de crescimento, pode-se sugerir que houve um menor direcionamento do nitrogênio absorvido para o crescimento das folhas no segundo periodo de crescimento. Este modelo de partição do nitrogênio observado no segundo crescimento pode ser resultante da competição por nutrientes estabelecida pelos sítios ativos de crescimento na planta. Cruz \& Boval (1999) apontaram que em plantas estoloniferas tanto estolões como folhas representam sitios ativos de absorção de assimilados, o que pode levar a uma menor resposta de taxa de expansão foliar em caso de competição por nutrientes como observado para o capim-Tifton 85 . No segundo corte observou-se ainda um maior perfilhamento da forrageira. 


\subsection{Experimento III}

A análise de variância mostrou efeito significativo $(P<0,05)$ das doses de nitrogênio no valor SPAD e na concentração de nitrogênio no tecido foliar. $A$ variação no valor das unidades SPAD foi representada por modelos quadráticos tanto no primeiro como no segundo crescimento, com valores de coeficiente de determinação de 0,99 e 0,99, respectivamente. A concentração de nitrogênio no tecido relacionou-se às doses de nitrogênio por uma regressão quadrática no primeiro crescimento e linear no segundo, com valores de coeficiente de determinação de 0,99 e 0,88, respectivamente (Figuras 19 e 20). À medida em que a disponibilidade de nitrogênio para a planta aumenta, mais clorofila é produzida na folha e a planta expressa essa resposta aumentando a coloração verde (Bullock \& Anderson, 1998), cuja intensidade é medida pelo clorofilômetro.

Os valores máximos de unidades SPAD estimados pela regressão, 39,42 e 44,20, seriam obtidos com o suprimento de nitrogênio além da máxima dose utilizada no experimento, ou seja, 318 e $379 \mathrm{mg} \mathrm{kg}^{-1}$ de solo para o primeiro e segundo crescimentos, respectivamente. A concentração máxima estimada de nitrogênio na lâmina foliar $\left(42,21 \mathrm{~g} \mathrm{~kg}^{-1}\right)$, correspondeu à dose de nitrogênio de $406 \mathrm{mg} \mathrm{kg}^{-1}$ de solo, para o primeiro crescimento.

Shepers et al. (1992), estudando híbridos de milho submetidos a doses de fertilizante nitrogenado, verificaram que as leituras no clorofilômetro atingiram um platô em doses de nitrogênio mais elevadas do que $225 \mathrm{~kg} \mathrm{ha}^{-1}$. A concentração de nitrogênio nas folhas contudo, sofreu incrementos até a mais alta dose de nitrogênio aplicada, de $300 \mathrm{~kg} \mathrm{ha}^{-1}$. Esse modelo de resposta em relação ao SPAD segue as mesmas tendências observadas para o capim-Tifton 85, e a resposta em termos de concentração de nitrogênio na folha é compativel com o segundo crescimento (Figura 20). Uma relação que se ajusta a uma equação de segundo grau, entre a dose aplicada de nitrogênio no solo e 
valores os SPAD na folha também foi observada por Kantety et al. (1996) com festuca.

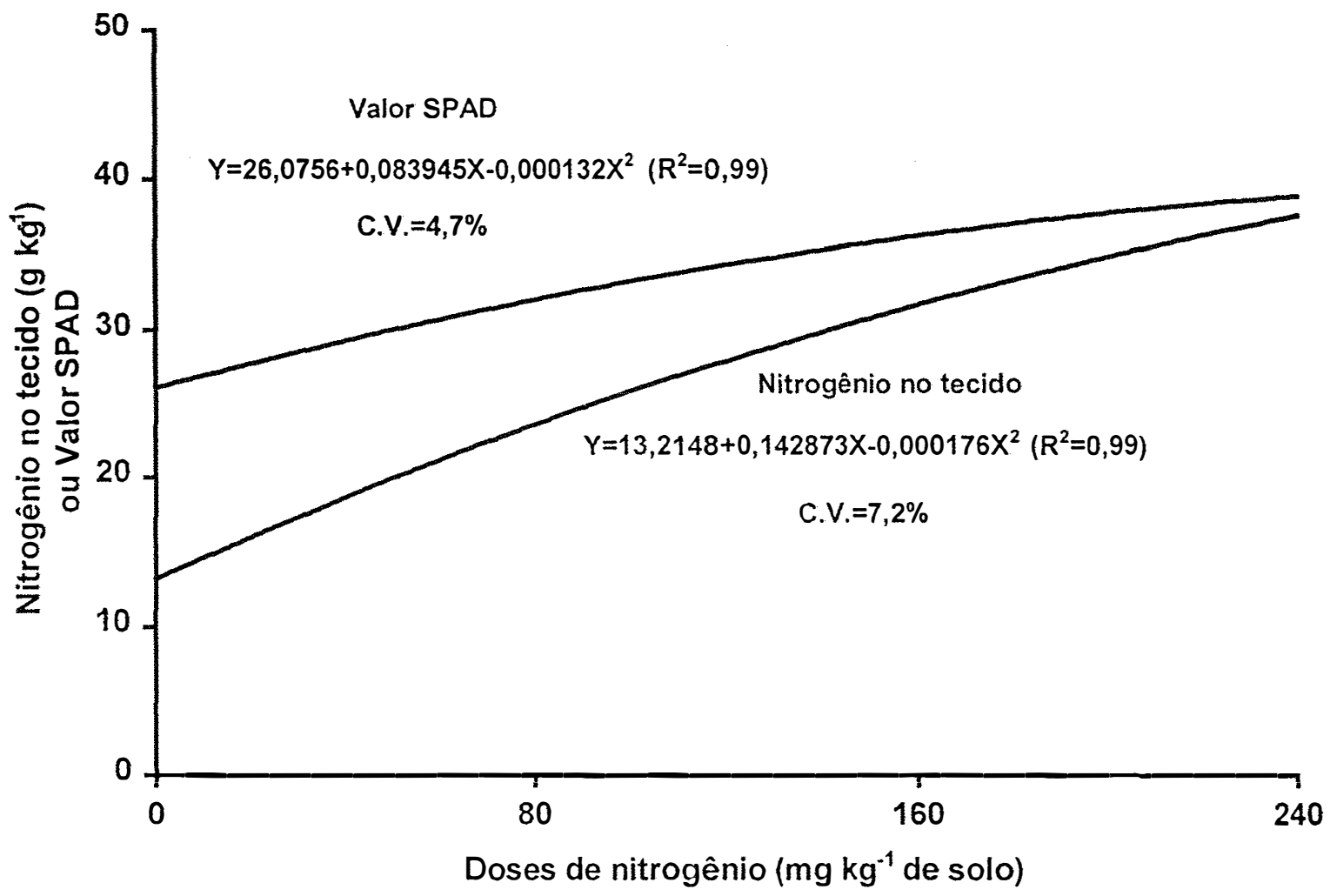

Figura 19 - Valor SPAD e concentração de nitrogênio no tecido foliar no primeiro crescimento do capim-Tifton 85 , em função das doses de nitrogênio. 


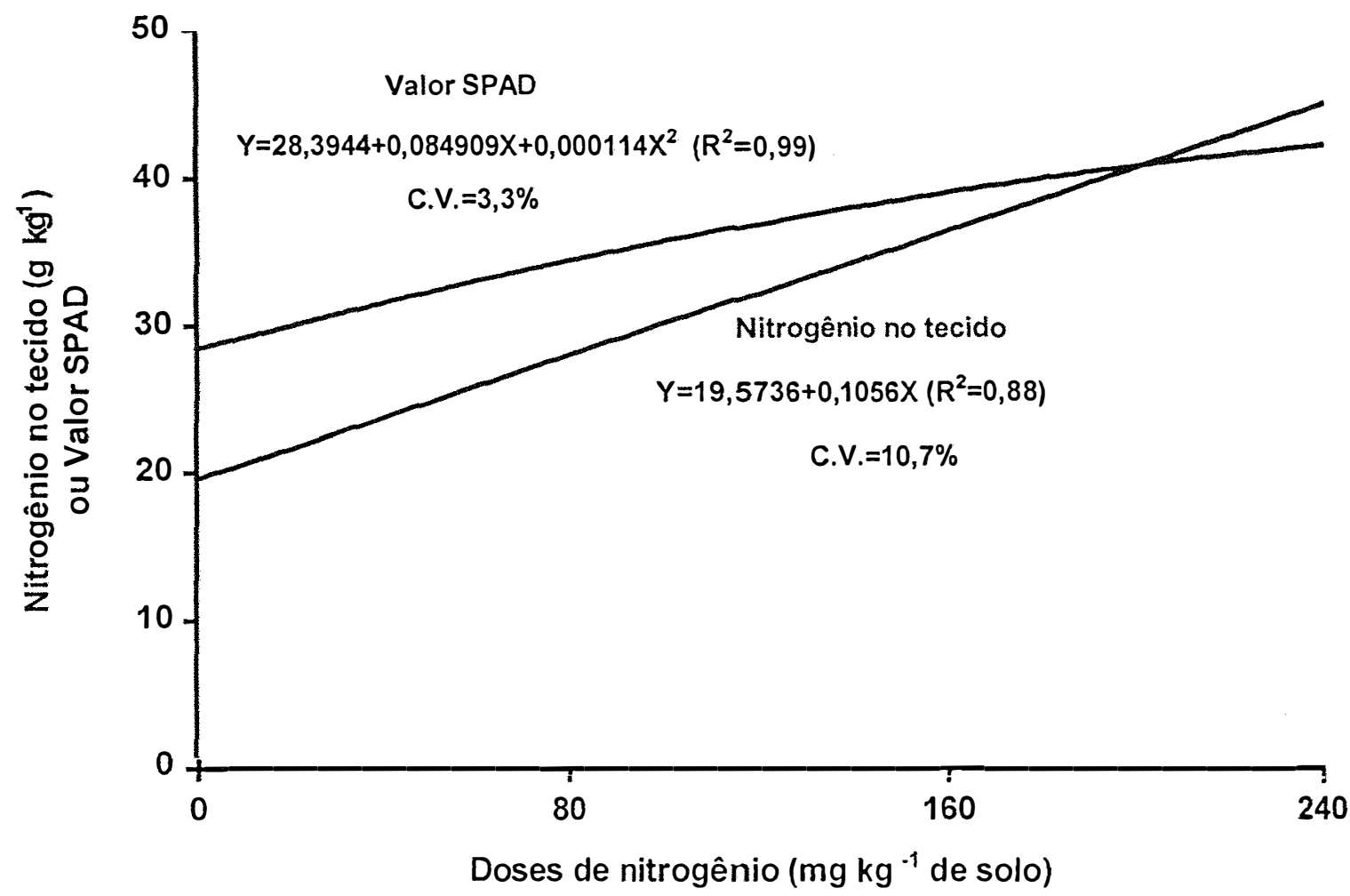

Figura 20 - Valor SPAD e concentração de nitrogênio no tecido foliar no segundo crescimento do capim-Tifton 85 , em função das doses de nitrogênio.

Modelo quadrático para a relação entre o valor de unidades SPAD e doses de nitrogênio também foi observado por Santos (1997), com valores semelhantes de ajuste para o modelo $(0,81$ e 0,98 , para o primeiro e segundo crescimento, respectivamente). Os máximos valores de unidades SPAD encontrados no capim-braquiária $(50,2$ e 52,0) foram superiores aos observados neste experimento com o capim-Tifton 85 (39,4 e 44,2).

O modelo de resposta quadrática a doses de nitrogênio para leitura SPAD também foram relatadas com outras forrageiras como capim-Tanzânia (Schiavuzzo et al., 1998b) e capim-Aruana (Colozza, 1998), capins Marandu e Tanzânia (Abreu, 1999), capim-Mombaça (Manarin, 2000), 
Para o capim-Tifton 85 o valor SPAD e a concentração de nitrogênio na lâmina foliar correlacionaram-se significativamente $(P<0,05)$, tendo sido constatados coeficientes de 0,97 para o primeiro e 0,92 para o segundo crescimento. Estudando híbridos de milho, Bullock \& Anderson (1998) observaram correlação significativa entre o valor SPAD e concentração de nitrogênio na folha, com os coeficientes de correlação variando em função do estágio de crescimento da cultura $(0,33 ; 0.35$ e 0.78 para os estágios $V 7, R 1$ e $\mathrm{R} 4$, respectivamente).

No experimento com o capim-Tifton 85 foi observada relação significativa $(P<0,05)$ entre o valor $S P A D$ e a concentração de nitrogênio na lâmina foliar, relação essa que foi expressa por uma equação de primeiro grau $\left(R^{2}=0,95\right)$ no primeiro crescimento e por uma equação de segundo grau $\left(R^{2}=0.89\right)$ no segundo crescimento (Figura 21$)$. No segundo crescimento o valor máximo de SPAD estimado corresponde a concentração de nitrogênio no tecido foliar de $57 \mathrm{~g} \mathrm{~kg}^{-1}$.

Wood et al. (1992) obtiveram para a cultura de milho o valor de coeficiente de correlação $\left(R^{2}\right)$ de 0,90 para relação entre os valores de unidades SPAD e a concentração de nitrogênio na folha. Blackmer et al. (1994), estudando híbridos de milho, obtiveram relação linear entre concentração de nitrogênio na folha e a leitura SPAD, com $R^{2}=0,84$. Santos (1997) também verificou altos coeficientes de correlação entre os valores SPAD e a concentração de nitrogênio nas lâminas de folhas recém-expandidas de capim-braquiária, com valores de $R^{2}$ de 0,91 e 0,93 para o primeiro e segundo crescimentos, respectivamente. 


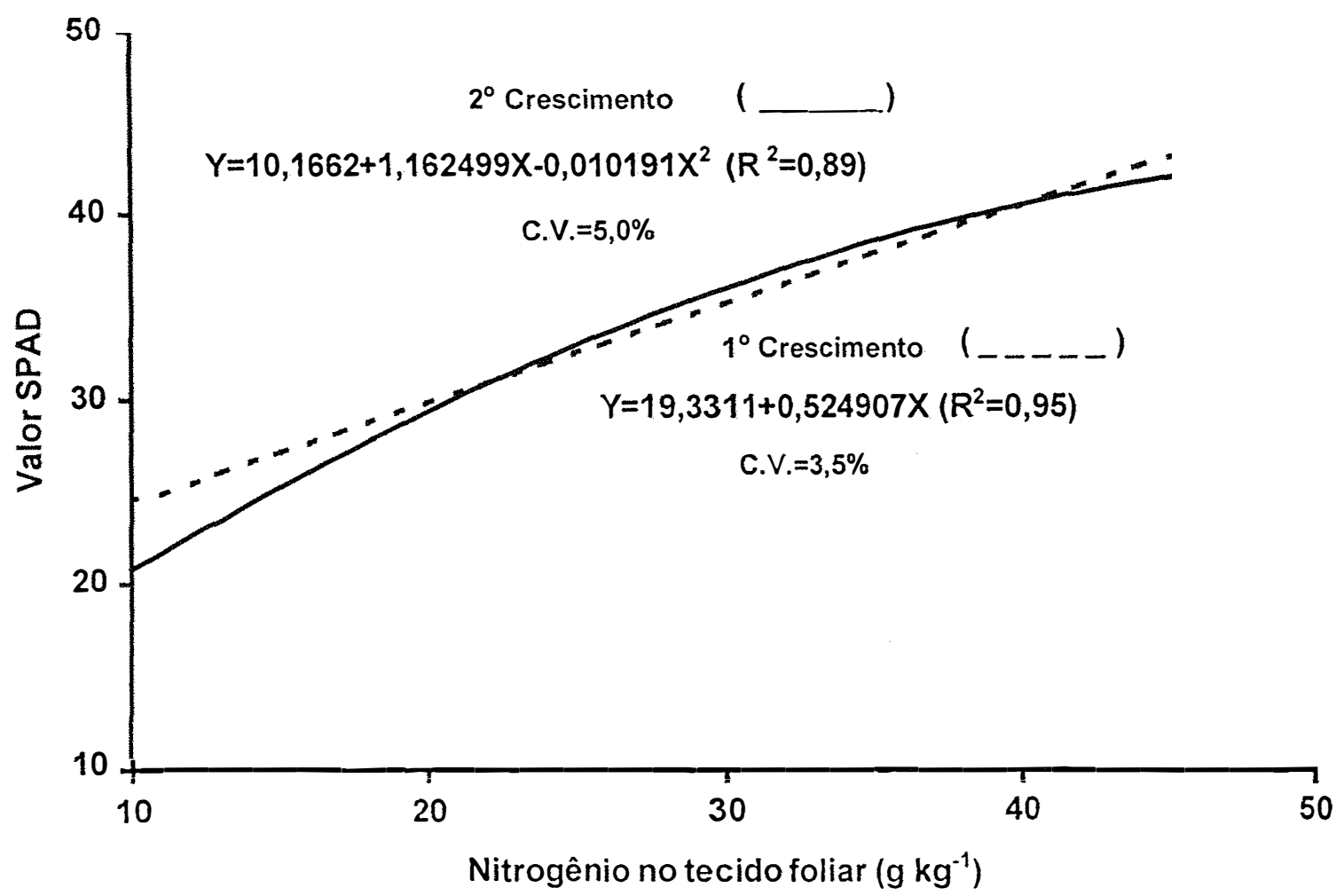

Figura 21 - Relação entre as unidades de valor SPAD e a concentração de nitrogênio na lâmina foliar para do capim-Tifton 85 , em dois períodos de crescimento da forrageira recebendo adubação nitrogenada.

Abreu (1999) cultivando o capim-Marandu encontrou alta correlação entre leitura SPAD e a concentração de nitrogênio nas lâminas de folhas recémexpandidas, com coeficientes de 0,73; 0,80 e 0,92 para os estádios de 14, 28 e 42 dias de crescimento, respectivamente. Para o capim-Tanzânia o mesmo autor relatou que os valores foram 0,$79 ; 0,89 ; 0,90$ para os estádios de 14,28 e 42 dias de crescimento, respectivamente.

Os resultados do presente experimento, em plena consonância com aqueles disponíveis na literatura, comprovam clara relação entre o suprimento de nitrogênio e unidades SPAD verificadas nas lâminas de lâminas de folhas 
recém-expandidas da gramínea forrageira. De forma similar, alta correlação entre essas unidades SPAD e a concentração de nitrogênio nessas mesmas lâminas foliares é também documentada. 


\section{CONCLUSÕES}

As doses de nitrogênio interferiram significativamente no fator de correção de área foliar, na produção de matéria seca da parte aérea e das raízes, na relação colmo+bainha/lâmina foliar, na concentração de nitrogênio no tecido foliar, no perfilhamento, no crescimento de folhas e nas unidades do valor SPAD;

Dentro das doses de nitrogênio estudadas predominou decréscimo no valor do fator de correção de área foliar e acréscimos no número de perfilhos, no comprimento e área foliares e nas unidades de valor SPAD;

As épocas de aplicação de nitrogênio, imediatamente após o corte e sete dias após o mesmo, mostraram diferença significativa para produção de matéria seca de raízes, concentração de nitrogênio da parte aérea e no comprimento e área foliares;

A aplicação de nitrogênio sete dias após o corte proporcionou mais elevada concentração de nitrogênio na parte aérea da forrageira e mais baixa produção de matéria seca de raízes em relação a aplicação no momento do corte;

Altos coeficientes de correlação foram constatados entre número total de perfilhos e produção de matéria seca da parte aérea e entre as unidades de valor SPAD e concentração de nitrogênio nas folhas recém-expandidas. 


\section{REFERÊNCIAS BIBLIOGRÁFICAS}

ABREU, J.B.R. Produção e nutrição dos capins Tanzânia-1 e Marandu em função de estádios de crescimento e adubação nitrogenada. Piracicaba, 1999. 99p. Tese (Doutorado) Escola Superior de Agricultura "Luiz de Queiróz, Universidade de São Paulo.

ALVES, M.J. Rendimento forrageiro e valor nutricional do capim Tifton 85 (Cynodon spp), sob diferentes doses de nitrogênio, colhido ao atingir 30, 40 e $50 \mathrm{~cm}$ de altura . Viçosa, 2000. 53p. Dissertação (M.S.) Universidade Federal de Viçosa.

ALVIM, J.A; BOTREL, M.A; MARTINS, C.E.; CÓSER, A.C.; RESENDE, H; VILELA, D. Efeito de doses de nitrogênio e de intervalos entre cortes sobre a produção de matéria seca e teor de proteína bruta do Tifton 85 . In: REUNIÃO DA SOCIEDADE BRASILEIRA DE ZOOTECNIA, 35., Botucatu, 1998. Anais. Botucatu : SBZ,1998. p.492-494.

ALVIM, M.J.; RESENDE, H.; BOTREL, M. Efeito da freqüência de cortes e do nível de nitrogênio sobre a produção e qualidade da matéria seca do "coast cross". In: WORKSHOP SOBRE O POTENCIAL FORRAGEIRO DO GÊNERO CYNODON, Juiz de Fora, 1996. Anais. Juiz de Fora: EMBRAPA, CNPGL, 1996. p. 45-75. 
ANDREWS, M.; McKENZIE, B.A.; JONES, A.V. Nitrate effects on growth of the first four main stem leaves of a range of temperate cereals and pasture grasses. Annals of Botany, v.67,n.5,p.451-457,1991.

ANDREWS, M.; MORTON, J.D.; LIEFFERING, M.; BISSET, L. The partitioning of nitrate assimilation between root and shoot of a range of temperate cereals and pature grasses. Annals of Botany, v.70,n.3, p.271-276,1992.

BÉLANGER, G. Morphogenetic characteristics of timothy grown with varying $N$ nutrition. Canadian Journal of Plant Science,v.78,n.1,p.103-108, 1998.

BÉLANGER, G.; GASTAL, F.; LEMAIRE, G. Growth analysis of a tall fescue sward fertilized with different rates of nitrogen. Crop Science, v.32,p.1371$1376,1992 a$.

BÉLANGER, G.; GASTAL, F.; WAREMBOURG, F.R. The effects of nitrogen fertilization and the growing season on carbon partitioning in a sward of tall fescue (Festuca arundinacea Schereb). Annals of Botany, v. 70,p.239$244,1992 b$.

BLACKMER, T.M.; SCHEPERS, J.S.; VARVEL, G.E. Light reflectance compared with other nitrogen stress measurements in corn leaves. Agronomy Journal, v.86,p.934-938,1994.

BOGGIANO, P.; MARASCHIN, G.; NABINGER, C.; RIBOLDI, J.; CADENAZZI, M.; ROSA, L.M. Effect of the herbage allowance and nitrogen fertilization on tiller density and weight of Paspalum notatum Flügge in a natural pasture in Rio Grande do Sul. In: INTERNATIONAL SYMPOSIUM ON GRASSLAND ECOPHYSIOLOGY AND GRAZING ECOLOGY, Curitiba, 1999. Curitiba: UFPR, 1999. p.391-394. 
BOOT, R.G.A.; MENSINK, M. Size and morphology of root systems of perennial grasses from contrasting habitats as affected by nitrogen supply. Plant and Soil, v.129,n.2,p.291-299,1990.

BULLOCK, D.G.; ANDERSON, D.S. Evaluation of the Minolta SPAD-502 chlorophyll meter for nitrogen management in corn. Journal of the Plant Nutrition, v.21, n.4, p. 741-755, 1998.

BURTON, G.W.; GATES, R.N.; HILL, G.M. Registration of "Tifton 85" bermudagrass. Crop Science, v.33,n.3,p.644-645,1993.

CARNEVALLI, R.A.; DA SILVA, S.C. da; PEDREIRA, C.G.S.; FAGUNDES, J.L.; DE CARVALHO, C.A.B.; SBRISSIA, A.F.; PINTO, L.F.M.; UEBELE, M.C.; PASSANEZI, M.M. Pasture and animal responses of Tifton 85 swards grazed by sheep under continuous stocking. In: INTERNATIONAL SYMPOSIUM ON GRASSLAND ECOPHYSIOLOGY AND GRAZING ECOLOGY, Curitiba, 1999. Curitiba: UFPR, 1999. p.357-361.

CECATO, U.; FAVORETTO, V.; MALHEIROS, E.B. Freqüências de corte, niveis e formas de aplicação de nitrogênio sobre as características da rebrota do capim-Aruana (Panicum maximum Jacq cv ARUANA). Revista UNIMAR,v.16,n.3,p.263-276, 1994.

CHAPMAN, D.F.; LEMAIRE, G. Morphogenetic and structural determinants of plant regrowth after defoliation. In: INTERNATIONAL GRASSLAND CONGRESS,17., Palmerston North, 1993. Proceedings. Palmerston North: Tropical Grassland,1993.p.95-104. 
COLOZZA, M.T. Rendimento e diagnose foliar dos capins Aruana e Mombaça cultivados em latossolo vermelho-amarelo adubado com doses de nitrogênio. Piracicaba, 1998. 127p. Doutorado (Tese) Escola Superior de Agricultura "Luiz de Queiróz" Universidade de São Paulo.

CORSI, M.; NASCIMENTO Jr.,D. Principios de fisiologia e morfologia de plantas forrageiras aplicados no manejo das pastagens. In: PEIXOTO,A.M.; MOURA,.J.C.de; FARIA,V.P.de. (Ed.) Pastagens: fundamentos da exploração racional. Piracicaba: FEALQ,1986.p.11-37.

CRUZ, P.; BOVAL, M. Effect of nitrogen on some morphogenetical traits of temperate and tropical perennial forage grasses. In: INTERNATIONAL SYMPOSIUM ON GRASSLAND ECOPHYSIOLOGY AND GRAZING ECOLOGY, Curitiba, 1999. Curitiba: UFPR, 1999. p.134-150.

DALE, J.L. The control of leaf expansion. Annual Review of Plant Physiology and Plant Molecular Biology, v.39,p.267-295, 1988.

DAVIES, A. Tissue turnover in the sward. Sward measurement handbook. In: HOGDSON,J.; BAKER, R.D.; DAVIES, A.; LAIDLAW, A.S.; LEAVER, J.D. (Ed.) Sward measurement handbook. Hurley: The British Grassland Society, 1981. p.197-209.

DWYER, L.M.; TOLLENAAR, M.; HOUWING, L. A nondestructive method to monitor leaf greenness in corn. Canadian Journal of Plant Science,v.71, p.505-509,1991. 
EMPRESA BRASILEIRA DE PESQUISA AGROPECUÁRIA. Centro Nacional de Pesquisa de Solos. Rio de Janeiro, Sistema brasileiro de classificação de solos. Brasilia: Embrapa, Produção de Informação; Rio de Janeiro: Embrapa Solos, 1999. 42p.

ENGELS, C.; MARSCHNER, H. Plant uptake and utilization of nitrogen. In: BACON,P.E.(Ed.) Nitrogen fertilization in the environment. New York: Marcel Dekker, 1995.p.41-81.

FERRARI JR., E.; RODRIGUES, L.R.A.; REIS, R.A.; COAN, O.; SCHAMMASS, E.A. Avaliação do capim Coast cross para produção de feno em diferentes idades e niveis de adubação de reposição. Boletim da Indústria Animal,v.50,n.2,p.137-145, 1993.

FRICKE, W.; McDONALD, A.J.S.; MATTSON-DJOS, L. Why do leaves and leaf cells on $\mathrm{N}$-limited barley elongate at reduced rates? Planta,v.202,n.4,p.522$530,1997$.

GASTAL, F.; BELANGER, G.; LEMAIRE, G. A model of the leaf extension rate of tall fescue in response to nitrogen and temperature. Annals of Botany, v.70,p.437-442, 1992 .

GOMES, L.H.; CECATO, U.; ITAVO, C.V.; MEDRONI, S. Avaliação de cultivares do gênero Cynodon sob dois niveis de adubação nitrogenada. In: REUNIÃO DA SOCIEDADE BRASILEIRA DE ZOOTECNIA, 34., Juiz de Fora, 1997. Anais. Juiz de Fora: SBZ,1997. p.33-35. 
GOMIDE, C.C.C. Algumas caracteristicas fisiológicas e químicas de cinco cultivares de Cynodon. Jaboticabal, 1996.100p. Dissertação (Mestrado) Faculdade de Ciências Agrárias e Veterinárias de Jaboticabal, Universidade Estadual Paulista "Julio de Mesquita Filho".

HARRIS, S.L.; THOM, E.R.; CLARK, D.A. Effect of high rates of nitrogen fertilizer on perennial ryegrass growth and morphology in grazed dairy pasture in northern New Zealand. New Zealand Journal of Agricultural Research,v.39,n.1,p.159-169, 1996.

HERLING, V.R.; ZANETTI, M.A.; GOMIDE, C.A; LIMA, C.G de. Influência de niveis de adubações nitrogenadas e potássica e estádios de crescimento sobre o capim-setária (Setária anceps Stapf Ex. Massey cv. Kazungula). 1. Produção de matéria seca e fisiologia de perfilhamento. Revista da Sociedade Brasileira de Zootecnia,v.20,n.6,p.561-571,1991.

HERRERA, R.S.; RAMOS, N.; HERNANDEZ, Y. Bermuda grass response to nitrogen fertilization and age regrowth. VI. Performance of the yield components. Cuban Journal of Agricultural Science,v.21,n.1,p.85-91, 1987.

HILL, G.M.; GATES, R.N.; BURTON, G.W. Forage quality and grazing steer performance from Tifton 85 and Tifton 78 bermudagrass pastures. Journal of Animal Science,v.71,p.3219-3225,1993.

HILL, G.M.; GATES, R.N.; WEST, J.W.; BURTON, G.W.; Tifton bermudagrass utilization in beef, dairy, and hay production. In: WORKSHOP SOBRE $O$ POTENCIAL FORRAGEIRO DO GENERO CYNODON, Juiz de Fora, 1996. Anais. Juiz de Fora: EMBRAPA, CNPGL, 1996. p.139-150. 
HOFFMANN, C.R.; FAQUIN, V.; GUEDES, G.A.A.; EVANGELISTA, A.R. O nitrogênio e o fósforo no crescimento da braquiária e do colonião em amostras de um latossolo da região noroeste do Paraná. Revista Brasileira de Ciência do Solo,v.19,n.1,p.79-86, 1995.

JEWISS, O.R. Tillering in grasses-its significance and control. Journal of Bristish Grassland Society,v.27,p.65-82,1972.

KANTETY, R.V.; SANTEN, E. van; WOODS, F.M.; WOOD, C.W. Chlorophyll meter predicts nitrogen status of tall fescue. Journal of Plant Nutrition, v.19, n.6, p.881-899,1996.

LANGER, R.H.M. Tillering in herbage grasses. Herbage Abstracts, v.33, n.3,p.141-148,1963.

LAWLOR, D.W. Photosynthesis, productivity and environment. Journal of Experimental Botany, v46,n.spec.iss,p.1449-1461,1995.

LEMAIRE, G. The physiology of grass growth under grazing. In: SIMPÓSIO INTERNACIONAL SOBRE PRODUÇÃO ANIMAL EM PASTEJO. INTERNATIONAL SYMPOSIUM ON ANIMAL PRODUCTION UNDER GRAZING, Vicosa,1997. Proceedings. Viçosa: UFV, Depto de Zootecnia, 1997.p.116-144

LYTTLETON, J.W. Proteins and nucleic acids. In: BUTLER, G.W.; BAILEY, R.W. (Ed.) Chemistry and biochemistry of herbage. New York: Academic Press, 1973.v.1,p.63-103. 
MAAN, A.A.S.; WRIGHT, D.; ALCOCK, M.B. Effects of sowing date, sowing density and nitrogen supply on leaf extension in spring barley. Journal of Agricultural Science, v.113,p.305-315,1989.

MADAKADZE, I.C.; STEWART, K.A. MADAKADZE, R.M.; PETERSON, P.R.; COULMAN, B.E.; SMITH, D.L. Field evaluation of the chlorophyll meter to predict yield and nitrogen concentration of switchgrass. Journal of Plant Nutrition, v. 22, n.6,p.1001-1010, 1999.

MANARIN, C.A. Respostas fisiológicas, bioquímica e produtivas do capimMombaça a doses de nitrogênio. Piracicaba, 2000. 59p. Mestrado (Dissertação) Escola Superior de Agricultura "Luiz de Queiróz", Universidade de São Paulo.

MANDEBVU, P.; WEST, J.W.; GATES, R.N.; HILL, G.M. Effect of hay maturity, forage source, or neutral detergent fiber content on digestion of diets containing Tifton 85 bermudagrass and corn silage. Animal Feed Science and Tecnology,v.73,n.3/4,p.281-290,1998a

MANDEBVU,P.; WEST,J.W.; GATES,R.N.; HILL,G.M. In vitro digestion kinetics of neutral detergent fiber extracted from Tifton 85 and Coastal bermudagrasses. Animal Feed Science and Tecnology,v.73,n.3/4,p.263$269,1998 b$.

MANDEBVU, P.; WEST, J.W.; HILL, G.M.; GATES, R.N.; HATFIELD, R.D.; MULLINIX, B.G.; PARKS, A.H.; CAUDLE, A.B. Comparison of Tifton 85 and Coastal bermudagrasses for yield, nutrient traits, intake, and digestion by growing beef steers. Journal of Animal Science,v.77,n.6,p.1572-1586, 1999. 
MARSCHNER, $H$. Mineral nutrition of higher plants. 2.ed. New York: Academic Press, 1995. 889p.

MARTIM, R. A . Doses de nitrogênio e de potássio para produção, composição e digestibilidade dos capins Coastcross e de Tifton 85 em um latossolo vermelho-amarelo. Piracicaba, 1997. 109p. Dissertação (Mestrado) Escola Superior de Agricultura "Luiz de Queiroz", Universidade de São Paulo.

MATTHEW, C.; ASSUERO, S.G.; BLACK, C.K.; SACKVILLE HAMILTON, N.R. Tiller dynamics of grazed swards. In: INTERNATIONAL SYMPOSIUM ON GRASSLAND ECOPHYSIOLOGY AND GRAZING ECOLOGY, Curitiba, 1999. Curitiba: UFPR, 1999. p.109-133.

MATTOS, J.L.S. de; PINTO, J.C.; OLIVEIRA, L.E.M. de; MORAIS, A.R de. Influência da disponibilidade de água e nitrogênio sobre caracteristicas morfológicas de gramineas forrageiras. Ciência e Agrotecnologia,v.21,n.4,p.495-501, 1997.

McKENZIE, F.R. Influence of applied nitrogen on vegetative, reproductive, and aerial tiller densities in Lolium perenne L. during the establishment year. Australian Journal of Agricultural Research, v.49,n.4,p.707-711,1998.

MENGEL, K.; KIRKBY, E.A. Principles of plant nutrition. 4.ed. Bern: International Potash Institute, 1987.687p.

MISLEVY, P.; PATE, F.M. Establishment, management, and utilization of Cynodon grasses in Florida. In: WORKSHOP SOBRE O POTENCIAL FORRAGEIRO DO GÉNERO CYNODON, Juiz de Fora, 1996. Anais. Juiz de Fora: EMBRAPA, CNPGL, 1996. p.127-138. 
MONTEIRO, F.A. Adubação em áreas de Cynodon para pastejo e conservação. In: SIMPÓSIO SORE MANEJO DA PASTAGEM, 15., Piracicaba, 1998. Anais. Piracicaba:FEALQ. 1998. p.173-202.

NABINGER,C. Princípios da exploração intensiva de pastagens. In: SIMPÓSIO SOBRE MANEJO DA PASTAGEM, 13., Piracicaba, 1996. Anais. Piracicaba: FEALQ, 1997. p.15-95.

NABINGER,C. Eficiência do uso de pastagens: disponibilidade e perdas de forragem. In: SIMPÓSIO SOBRE MANEJO DA PASTAGEM, 14., Piracicaba, 1997. Anais. Piracicaba: FEALQ, 1998. p.213-251.

OURRY, A.; BOUCAUD, J.; SALETTE, J. Nitrogen mobilization from stubble and roots during re-growth of defoliated perennial ryegrass. Journal of Experimental Botany, v.39,n.203,p.803-809,1988.

OVERMAN, A.R.; WILKINSON, S.R. Partitioning of dry matter between leaf and stem in coastal bermudagrass. Agricultural Systems,v.30,n.1,p.35-47, 1989.

PALHANO, A.L. Recrutamento de nutrientes e valor nutritivo de Cynodon dactylon (L.) Pers. Cv. Coastcross n`1. Piracicaba, 1990. 122p. Dissertação (Mestrado) - Escola Superior de Agricultura "Luiz de Queiróz", Universidade de São Paulo.

PAULINO, T.V.; SCHUNKE, R.; CANTARELLA, H. Avaliação do nível de nitrogênio em quatro cultivares de Panicum maximum Jacq. através da medida indireta de clorofila. In: REUNIÃO DA SOCIEDADE BRASILEIRA DE ZOOTENIA, 35., Botucatu,1998. Anais. Botucatu: SBZ,1998. p.427-429. 
PAULINO, V.T.; GERDES, I.; CARVALHO, D.D.; LUCENA, M.A.C. AMARO, F.R.; FERREIRA, T.A. Fontes e doses de nitrogênio na produção, teor de proteína bruta e perfilhamento do capim Tifton 85 (Cynodon spp). In: REUNIÃO DA SOCIEDADE BRASILEIRA DE ZOOTECNIA, 34., Juiz de Fora, 1997. Anais. Juiz de Fora: SBZ,1997. p. 142-144.

PEARSE, P.J.; WILMAN, D. Effects of applied nitrogen on grass leaf initiation, development and death in field swards. Journal of Agricultural Science,v.103,p.405-413,1984.

PEDREIRA, C.G.S. Plant and animal responses on grazed pastures of "Florakirk" and "Tifton 85" bermerdagrasses. Gainesville, 1995. 153p. Thesis (Ph.D.) - University of Florida.

PEDREIRA, C.G.S.; NUSSIO, L.G.; SILVA, S.C da. Condições edafo-climáticas para produção de Cynodon spp. In: SIMPÓSIO SOBRE MANEJO DA PASTAGEM, 15., Piracicaba, 1998. Anais. Piracicaba: FEALQ, 1998. p.85113.

PENG, S.; GARCÍA, F.V.; LAZA, R.C.; CASSMAN, K.G. Adjustment for specific leaf weight improves chlorophyll meter's estimate of rice leaf nitrogen concentration. Agronomy Journal, v.85,p.987-990,1993.

PINTO, J.C.; GOMIDE, J.A.; MAESTRI, M. Produção de matéria seca e relação folha/caule de gramineas forrageiras tropicais, cultivadas em vasos, com duas doses de nitrogênio. Revista da Sociedade Brasileira de Zootecnia,v.23,n.3,p.313-326, 1994a. 
PINTO, J.C.; GOMIDE, J.A..; MAESTRI, M.; LOPES, N.F. Crescimento de folhas de gramineas forrageiras tropicais, cultivadas em vasos com duas doses de nitrogênio. Revista da Sociedade Brasileira Zootecnia, v.23, n.3,p.327-332,1994b.

RAIJ, B. van; QUAGGIO, J. A.; CANTARELLA, H.; FERREIRA, M.G.; LOPES, A.S.; BATAGLIA, O .C. Análise química do solo para fins de fertilidade. Campinas: Fundação Cargill, 1987. 170p.

ROBSON, M.J.; PARSONS, A.J. Nitrogen deficiency in small closed communities of S24 ryegrass. I. Photosynthesis, respiration, dry matter production and partition, Annals of Botany, v.42,p.1185-1197, 1978.

SANTOS, A. R. Diagnose nutricional e respostas do capim-braquiária submetido a doses de nitrogênio e enxôfre. Piracicaba, 1997. 115p. Tese (Doutorado) - Escola Superior de Agricultura "Luiz de Queiróz", Universidade de São Paulo.

SARRUGE, J.R.; HAAG, H.P. Análises químicas em plantas. Piracicaba: Livroceres, 1974. 55p.

SBRISSIA, A.F.; SILVA, S.C. da; MATTHEW, C.; PEDREIRA, C.G.S.; CARVALHO, C.A.B.; CARNEVALLI, R.A.; FAGUNDES, J.L.; PINTO, L.F.M.; CORTUCCI, M.; RODRIGUES, E.R. Tiller size/density compensation in grazed swards of Cynodon spp. In: INTERNATIONAL SYMPOSIUM ON GRASSLAND ECOPHYSIOLOGY AND GRAZING ECOLOGY, Curitiba, 1999. Curitiba: UFPR, 1999. p. 348-352. 
SHEARD, R.W. Organic reserves and plant regrowth. In: BUTLER, G.W.; BAILEY, R.W. (Ed.) Chemistry and biochemistry of herbage. New York: Academic Press, 1973.v.2,p.353-377.

SCHENK, U.; JÄGER, H.-J.; WEIGEL, H.-J. Nitrogen supply determines responses of yeld and biomass partitioning of perennial ryegrass to elevated atmospheric carbon dioxide concentrations. Journal of Plant Nutrition, v.19, n.10/11, p.1423-1440,1996.

SCHEPERS, J.S.; FRANCIS, D,D.; VIGIL, M.; BELOW, F.E. Comparison of corn leaf nitrogen concentration and chlorophyll meter readings. Communications in Soil Science and Plant Analysis,v.23,n.17/20, p.2173-2187, 1992.

SCHIAVUZZO, P.F.; LAVRES JR., J.; MONTEIRO, F.A. Respostas fisiológicas do capim-Marandu ao suprimento de nitrogênio. In: SIMPÓSIO DE INICIAÇÃO CIENTIFICA DA UNIVERSIDADE DE SÃO PAULO, 7., São Paulo, 1999. Anais. São Paulo: EDUSP, 1999. v.1,p.313.

SCHIAVUZZO, P.F.; MONTEIRO, F.A.; CARMELLO, Q.A.C.; BANKUTTI, A. Determinação do fator de correção para estimativa da área foliar em braquiária Marandu, cultivada em doses de nitrogênio. In: SIMPÓSIO DE INICIAÇÃO CIENTIFICA DA UNIVERSIDADE DE SÃO PAULO, 6., São Paulo, 1998. Anais. São Paulo: EDUSP. 1998a.v.1,p.498.

SCHIAVUZZO, P.F.; BENETTI, I.; MONTEIRO, F.A.; PREMAZZI, L.M. Leitura SPAD e concentração de nitrogênio na lâmina foliar do capim Tanzânia submetido a doses de nitrogênio In: SIMPOSIO DE INICIAÇÃO CIENTÍFICA DA UNIVERSIDADE DE SÃO PAULO, 6., São Paulo, 1998. Anais, São Paulo EDUSP, 1998b.v.1,p.499. 
SILVA, S.C .da. Manejo de plantas forrageiros dos gêneros Brachiária, Cynodon e Setária. In: PEIXOTO, A.M.; MOURA, J.C. de; FARIA, V.P de (Ed.) Volumosos para bovinos. 2.ed. Piracicaba: FEALQ, 1995.p.29-57.

SILVA,S.C.da; CORSI,M.; FARIA,V.P.de; Correção do solo e adubação de pastagens de capim-elefante. In: PEIXOTO,A.M.; MOURA,J.C. de; FARIA,V.P.de (Ed.) Pastagens de capim elefante: utilização intensiva. Piracicaba: FEALQ, 1996. p. 29-49. (Biblioteca de Zootecnia, 3).

SIMON, J.C.; LEMAIRE, G. Tillering and leaf area index in grasses in the vegetative phase. Grass and Forage Science, v.42,n.4,p.373-380,1987.

SINCLAIR, T.R.; HORIE, T. Leaf nitrogen, photosyntesis, and crop radiation use efficiency: a review. Crop Science, v..29,n.1,p.90-98,1989.

TAKEBE, M.; YONEYAMA, T. Measurement of leaf color scores and its implication to nitrogen nutrition of rice plants. Japan Agricultural Research Quarterly,v.23,n.2,p.81-93, 1989.

TAKEBE, M.; YONEYAMA, T.; INADA, K.; MURAKAMI, T. Spectral reflectance ratio of rice canopy for estimating crop nitrogen status. Plant and Soil, v.122, p.295-297,1990.

VIEIRA, S.A.; DAL FARRA, L.; ALTHOLF, D.A.; POLA, A.C. Avaliação do desempenho agronômico das forrageiras Tifton 85 e Missioneira gigante no litoral sul catarinense. Agropecuária Catarinense,v.12,n.1,p.11-14, 1999. 
VINCENTE-CHANDLER, J.; SILVA, S.; FIGARELLA, J. Effect of frequency of application on response of guinea grass to nitrogen fertilization. The Journal of Agriculture of the University of Puerto Rico,v.46,n.4,p.342349,1962 .

VOLENEC, J.J.; NELSON, C.J. Responses of tall fescue leaf meristems to $\mathrm{N}$ fertilization and harvest frequency. Crop Science,v.23,n.4,p.720-724, 1983.

WERNER, J.C.; PAULINO, V.T.; CANTARELLA, H.; ANDRADE, N.O.; GUAGGIO, J.A. Forrageiras. In: RAIJ, B. van; CANTARELLA, H.; QUAGGIO, J.A.; FURLANI, A.M.C.(Ed.) Recomendações de adubação e calagem para o Estado de São Paulo, 2.ed. Campinas: Instituto Agronômico de Campinas, 1996. p.263-272. (IAC. Boletim Técnico, 100).

WEST, J.W.; HILL, G.M.; GATES, R.N.; MULLINIX, B.G. Effects of dietary forage and amount of forage addition on intake, milk, yield, and digestion for lacting dairy cows. Journal of Dairy Science, v.80,p.1656-1665, 1997.

WEST, J.W.; MANDEBVU, P.; HILL, G.M.; GATES, R.N.; Intake, milk, yield and digestion by dairy cows fed diets with increasing fiber content from bermudagrass hay or silage. Journal of Dairy Science ,v.81,n.6,p.1599$1607,1998$.

WHITEHEAD, D.C. Grassland nitrogen. Wallingford: CAB International, 1995. $397 p$.

WILMAN, D.; PEARSE, P.J. Effects of applied nitrogen on grass yield, nitrogen content, tillers and leaves in field swards. Journal of Agricultural Science,v.103,p.201-211, 1984. 
WILMAN, D.; WRIGHT, P.T. Some effects of applied nitrogen on the growth and chemical composition of temperate grasses. Herbage Abstracts, v.53,n.8.p.387-393,1983.

WOLEDGE, J.; PEARSE, P. The effect of nitrogenous fertilizer on the photosynthesis of leaves of a ryegrass sward. Grass and Forage Science,v.40,n.3,p.305-309, 1985.

WOOD, C.W.; REEVES, D.W.; DUFFIELD, R.R., EDMISTEN, K.L. Field chlorophyll measurements for evaluation of corn nitrogen status. Journal of Plant Nutrition, v.15, n.4, p.487-500,1992. 